Columbia Law School

Scholarship Archive

1993

\title{
The Political Economy of the Wagner Act: Power, Symbol, and Workplace Cooperation
}

Mark Barenberg

Columbia Law School, barenberg@law.columbia.edu

Follow this and additional works at: https://scholarship.law.columbia.edu/faculty_scholarship

Part of the Labor and Employment Law Commons, Law and Politics Commons, and the Law and Society Commons

\section{Recommended Citation}

Mark Barenberg, The Political Economy of the Wagner Act: Power, Symbol, and Workplace Cooperation, 106 HARV. L. REV. 1379 (1993).

Available at: https://scholarship.law.columbia.edu/faculty_scholarship/934

This Article is brought to you for free and open access by the Faculty Publications at Scholarship Archive. It has been accepted for inclusion in Faculty Scholarship by an authorized administrator of Scholarship Archive. For more information, please contact scholarshiparchive@law.columbia.edu, rwitt@law.columbia.edu. 


\title{
HARVARD LAW REVIEW
}

\author{
THE POLITICAL ECONOMY OF THE WAGNER ACT: \\ POWER, SYMBOL, AND WORKPLACE COOPERATION
}

\author{
Mark Barenberg
}

\section{TABLE OF CONTENTS}

I. INTRODUCTION

II. The Origins of the Wagner Act: The Role of Interest Groups, Mass Politics, and Political Entrepreneurs ....................... 1392

A. Organized Labor: Historical Weakness, Ideological Passivity ............ 1393

B. Business: The Contingent Impotence of Well-Organized Interest Groups ..... I 1396

C. Mass Politics: Propulsive, Disruptive, but Indeterminate .............. I I399

D. The Crucible of the NLRA: The NRA Labor Boards and "the Education of

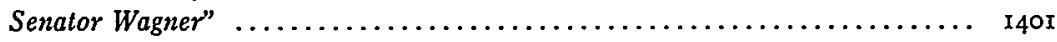

E. Progressive Policy Entrepreneurs, in and out of Government ............ ${ }^{4} 403$

F. The Fortuitous Role of "the Key Man in Congress" ................. I410

III. ROBERT WAGNER'S PROgRESSIVISM: "IF WE INTEND to PURSUE THE PHILOSOPHY

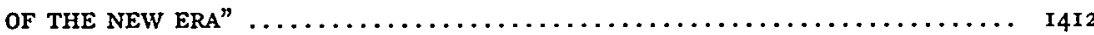

A. Pragnatist Premises: Scientific Guidance of the "Process of Becoming" ..... I4I 3

$B$. Social Control and Planning in the Administrative State ............... I415

C. "Building . .. a Co-operative Order" in the Age of Fordism .............. I418

D. Sovereign Power and Substantive Freedom in the Large-Scale Enterprise and the Polity .......................................... ${ }_{422}$

E. Labor-Management Cooperation in Progressive Labor Thought and Practice ... 1427

IV. The Role of Self-Reflexive Interests, Norms, and Trust in the Political ECONOMY OF THE WAGNER ACT $\ldots \ldots \ldots \ldots \ldots \ldots \ldots \ldots \ldots \ldots \ldots \ldots \ldots \ldots \ldots \ldots$ I 43 I

A. Processes of Interest-Transformation in the Origins and Impact of the Act .... $\mathrm{I} 43 \mathrm{I}$

r. Contingent Ideological Frameworks ....................... I43

2. The Perceived and Actual Symbolic Effects of the New Deal Labor Legislation ................................ 1434

3. Programmatic Debate Among Progressive Policy Entrepreneurs ......... 1439

$B$. Worker Interest-Formation and the Justification for the Ban on

Company Unions ................................... 1442

I. The Puzzle of the Justification for the Company Union Ban .......... I442

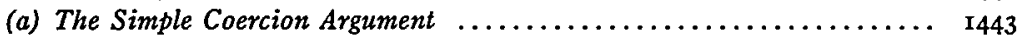

(b) The Contracting-Into-Slavery Argument ................... 1445

(c) The Empowerment Failure Argument $\ldots \ldots \ldots \ldots \ldots \ldots \ldots \ldots \ldots \ldots \ldots \ldots$ 
2. The Debate Among Political Entrepreneurs Over Company Unionism and Worker Consciousness ................................. 1450

(a) Progressivism and the Principle of Free Choice ............... I451

(b) Wagner's Unresolved Tension Between Individual and Group Consent 1454

(c) "Domination" Under Section $8(a)(2)$ as Structural Coercion and Hegemonic Interest-Formation ....................... 1456

C. Reciprocity, Trust, and Resentment in Workplace Cooperation ........... 1461

I. The Model of Internal Labor Markets and Relational Contracting ........ 1462

2. Wagner's Model of the Bargaining Problem and its Current Elaborations .. 1465

(a) Third-Party Enforcement ........................... 1468

(b) Self-Interested Reciprocity ........................... 1468

(c) Collective Empowerment and the Distributional Contest ............ I471

(d) Group Norms and Conventions ......................... 1475

(e) Trust, Resentment, and Endogenous Interests ............... 1478

(f) Wagner's Model in Sum: Gift-Exchange Through Empowerment ...... 1485

(g) Deliberative Trust and Hierarchical Resentment .............. 1487

V. Conclusion: The Limits and Ambiguities of WAgneR's Vision ......... I489 


\title{
ARTICLE
}

\section{THE POLITICAL ECONOMY OF THE WAGNER ACT: POWER, SYMBOL, AND WORKPLACE COOPERATION}

\author{
Mark Barenberg*
}

To shed light on the legal debate over new forms of workplace collaboration, this Article reexamines the origins of the National Labor Relations Act of 1935. Professor Barenberg conchudes that the Wagner Act scheme was profoundly cooperationist, not adversarial as is conventionally assumed. Revisionist historiography shows that, contrary to the clains of public choice theorists, Senator Wagner's network of political entrepreneurs was the decisive force in the conception and enactment of the new labor policy, amidst interest group paralysis and popular unrest. Drawing on original archival materials and oral histories, Professor Barenberg reconstructs the progressive ideology of Wagner and his circle. That elite network understood, consonant with recent critical theories, that legal symbols could shape worker consciousness. Their goal, however, was not to pacify but rather to galvanize workers to seek the collective empowerment that alone could secure democratic consent and cooperation in both the enterprise and in the polity in the era of mass production. Wagner rejected the leading interwar model of workplace cooperation - company unionism - because he believed it could not combine high-trust cooperation with protection of workers against instrumental and symbolic "domination" by employers. Unlike recent legaleconomic theorists who presume a world of self-interested, rational behavior, Wagner understood that workplace hierarchies generate cultural contests over trust and resentment. Wagner's model is more akin to current theories that maintain that human interests and perceptions - including dispositions toward trusting cooperation - are constituted intersubjectively and selfreflexively.

\section{INTRODUCTION}

$\mathrm{T}$ HIS Article reexamines the political and intellectual origins of the Wagner Act in order to reconstruct the vision of political economy, ideology, and law that impelled Robert Wagner's crusade to build a cooperative social democracy. It draws on historical evidence to illuminate two issues currently at the center of labor law: the substantive controversy over the appropriate legal policy toward innovations in workplace cooperation, and the methodological contest between

* Associate Professor of Law, Columbia Law School. For their help and encouragement, I thank Jim Atleson, Bernie Black, Vince Blasi, Richard Briffault, Ken Casebeer, Jack Coffee, Daniel Ernst, Martha Fineman, Terry Fisher, Steve Fraser, Josh Freeman, Ron Gilson, Vic Goldberg, Jeff Gordon, Milton Handler, Alan Hyde, Jim Liebman, Lance Liebman, Jerry Lynch, David Millon, Eben Moglen, Subha Narasimhan, Kellis Parker, Jim Pope, Simon Rifkind, Mark Roe, Chuck Sabel, Bill Simon, Peter Strauss, Kendall Thomas, and Michael Wachter. I am also grateful for financial support provided by Columbia Law School Alumnae/i. 
self-interested rationalism and symbolic constructionism for understanding labor relations and law. With varying degrees of explicitness, Robert Wagner's progressivism addressed both problems, and his "solutions" to them were tightly intertwined. He presaged, to a surprising degree, the more self-consciously theoretical views of several present approaches to labor relations specifically and to social conflict and coordination generally. These approaches hold that economic and political actors' desires, interests, perceptions, and identities are shaped endogenously and self-reflexively in the practices, discourses, and power relations of legal, political, and economic institutions. ${ }^{1}$ In this light, this Article portrays Wagner as an exemplar of those "practitioners" of institutional ordering whose "programs often profoundly shape our [theoretical] reflections on problems of coordination in unsuspected ways."2

The last decade brought with it a profusion of new and potentially contradictory analyses of the origins, impact, and desirable future of American labor law. These analyses can be roughly arrayed into two methodological categories - call them self-interested rationalism and symbolic-constructionism - which loosely correspond to the respective

1 These approaches contrast with traditional economic theory, which takes actors' subjective preferences, interests, and perceived choice constraints as "exogenous" variables, and explains or predicts actors' behavior on the assumption that they act rationally to satisfy those preferences and interests within the choice set or environmental constraints they face. See, e.g., HAL R. VARian, Microeconomic ANALysis Ir5-I8 (2d ed. I984); George J. Stigler \& Gary S. Becker, De Gustibus Non Est Disputandum, 67 AM. Econ. REv. 76, passim (1977); see also AMARTYA SEN, ON ETHICS AND ECONOMICS IO-18 (1987) (summarizing and criticizing the traditional theory); Michael S. McPherson, Want Formation, Morality, and Some "Interpretive" Aspects of Economic Inquiry, in SocIal SCIENCE AS MoRal INQUIRY 96, 98-1 Io (Norma Haan, Robert N. Bellah, Paul Rabinow \& William M. Sullivan eds., I983) (same). Often, economists assume that an economic or political actor's goals are narrowly self-interested if not pecuniary, are "reduc[ible] into a homogeneous descriptive magnitude," and generate complete and consistent value-orderings of the options faced by the actor. See SEN, supra, at 6r; see also infra pp. 1431, 1439-40.

Actors' subjective preferences, interests, and perceptions are "endogenous" if they are dependent variables of a particular theory or are the outcome of a causal relation. They are endogenous to institutional practices, discourses, or power relations if any of the latter are arguments or independent variables in the theory or causal relation. They are "self-reflexive" if actors, either individually or intersubjectively, evaluate and transform some of their own preferences and perceptions based on their other preferences and perceptions. See infra pp. 1431-34, 143542.

${ }^{2}$ Charles F. Sabel, Constitutional Ordering in Historical Context, in GAMES IN HiERARChIES AND NETWORKS (Fritz W. Scharpf ed., forthcoming) (manuscript at 37, on file at the Harvard Law School Library). Wagner's blend of academic, practical, and popular political economy is exemplary of the kind of policy-driven economic knowledge frequently generated by pivotally placed state actors. See Mary Turner \& Barry Supple, Ideas, Institutions, and State in the United Stales and Britain, in The STATE AND Economic KNowledge 3, 12-26 (Mary Turner \& Barry Supple eds., I990). In fact, Wagner and his circle were pioneers of such state-centered economic creativity. Present at the birth of the new macro-regulatory state, they elaborated self-consciously on particular social scientific programs of the day. See infra Part III. 
insurgencies of economic analysis and critical theory in legal scholarship. Legal economists located both the political origins of the New Deal labor policy and its economic impact in the self-interested, instrumental behavior of private and public individuals and organizations. For these and other public choice theorists, the Wagner Act ${ }^{3}$ was the product of the rent-seeking interests of organized labor; the Act, indeed, is the very paradigm of the private-regarding, interestgroup statute, and its proper interpretation must start with acknowledgement of this essential fact. ${ }^{4}$ In the analysis of legal economists, the Act either distorts efficiency by encouraging cartelization in the labor market ${ }^{5}$ or promotes efficiency by facilitating a workplace governance mechanism designed to protect against opportunistic subversion of internal labor markets and relational contracts. ${ }^{6}$ In either event, the Act's effect is explained by the self-interested, instrumental rationality of workers, unions, and firms.

Critical theorists underscore instead the symbolic and consciousness-shaping dimension of both the Act's origins and its impact. For some critical theorists, major initiatives in labor legislation such as the Wagner Act are symbolic interventions designed to defuse the social disruption of subordinate groups. ${ }^{7}$ For others, the subsequent judicial and administrative interpretation, and actual impact, of such legislation is explained in significant part by the ideological maps encoded in legal discourse. ${ }^{8}$

3 National Labor Relations Act of $x 935,29$ U.S.C. \$§ I5I-69 (I988) [hereinafter NLRA].

${ }^{4}$ See, e.g., Richard A. Epstein, A Common Law for Labor Relations: A Critique of the New Deal Labor Legislation, 92 YALE L.J. I357, I435, I44I (1983); Richard A. Posner, Some Economics of Labor Law, 5 I U. CHI. L. REV. 988, passim (1984) [hereinafter Posner, Some Economics]; Richard A. Posner, Economics, Politics, and the Reading of Statutes and the Constitution, 49 U. CHI. L. REv. 263, 273 (I982) [hereinafter Posner, Reading of Statutes].

5 See, e.g., Thomas J. Campbell, Labor Law and Economics, 38 STAN. L. REv. 991, 100422 (I986); Epstein, supra note 4, at I386-1408; Posner, Some Economics, supra note 4, at $99 \mathrm{I}$.

6 See, e.g., Douglas L. Leslie, Cases and Materdals on Labor LaW: Process aNd PoLICY 3I-34 (3d ed. I992); Michael L. Wachter \& George M. Cohen, The Law and Economics of Collective Bargaining: An Introduction and Application to the Problems of Subcontracting, Partial Closure, and Relocation, I36 U. PA. L. REv. I349, 1355-77, I386, I415 (1988). The "internal labor market" is the cluster of contractual rules that specify job classifications and seniority ladders, and the wages, benefits, and rights attached to such classifications and ladders. For a more detailed discussion, see below at pp. $\mathbf{r}_{462-65}$.

7 See Alan Hyde, A Theory of Labor Legislation, 38 Buff. L. Rev. 383, 385-92 (1990).

8 See, e.g., James B. Atleson, Values and Assumptions in American Labor Law passim (1983); Karl E. Klare, Critical Theory and Labor Relations Law, in THE PoLITICs of LAW: A PROGREssive CRITIQUe 6I, 8I (David Kairys ed., r990) ("IT]he richly textured doctrine of labor law that envelops and pervades the daily lives of all union officials and activists induces us to think about workplace problems in ways that defeat the effort to create industrial freedom." ); Katherine V.W. Stone, The Post-War Paradigm in American Labor Lare, go YALE L.J. 1509, I515-I6 (I98I) [hereinafter Stone, Post-War Paradigm]. Some critical scholarship also deploys instrumental analysis of the impact of labor law. See, e.g., Karl E. Klare, Workplace Democracy \& Market Reconstruction: An Agenda for Legal Reform, 38 CATH. U. L. REv. I, 
This ferment in theoretical approaches to labor law coincided with a period of flux in the actual practice of labor relations, which wakened some dormant labor law doctrines and statutory provisions. Experiments in "cooperative" workplace arrangements began in the I 970 s with relatively superficial innovations such as quality circles and joint labor-management committees, ${ }^{9}$ and deepened in the I980s and Iggos with the spread of full-blown cooperationist models of labormanagement relations. ${ }^{10}$ In the ideal implementation of these models, task conception and execution, which had been strictly separated between management and labor in the classic Taylorist workplace, ${ }^{11}$ are integrated in learning-intensive labor processes that depend upon continuous problem-solving by workers. Flexible, multiple-task workteam processes replace narrowly decomposed tasks and rigid job clas-

24-35 (1988); Joel Rogers, Divide and Conquer: Further "Reflections on the Distinctive Character of American Labor Laws," I9go Wisc. L. REv. 1, II-17; Katherine V.W. Stone, Labor and the Corporate Structure: Changing Conceptions and Emerging Possibilities, 55 U. CHI. L. REv. 73, I52-6r (1988) [hereinafter Stone, Labor and Corporate Structure]. Critiques of the thesis of the ideological or legitimating impact of law from within and outside of critical scholarship include Alan Hyde, The Concept of Legitimation in the Sociology of Law, 1983 Wisc. L. REv. 379, 400-17; Lewis A. Kornhauser, The Great Image of Authority, 36 STAN. L. REv. 349, 379-87 (1984); David M. Trubek, Where the Action Is: Critical Legal Studies and Empiricism, 36 STAN. L. REV. 575, 610-15 (1984). Nuanced defenses and reformulations of the thesis are presented in Mark Kelman, A Guide to Critical Legal Studies 242-95 (1987); J.M. Balkin, Ideology as Constraint, 43 STAN. L. REV. I133, I137-48 (1991); and Robert W. Gordon, Critical Legal Histories, 36 StaN. L. Rev. 57, 93-95 (1984).

9 "Quality circle" refers to a variety of workplace entities in which small groups of rank and file workers meet briefly on a regular basis (perhaps one hour per week), typically in the presence of management representatives, to discuss generally minor workplace grievances and production problems. See, e.g., Robert Cole, Strategies for learning: SMall-Group Activities IN AMERICAN, JAPANESE, AND Swedish INDUSTRY 19-33, 11 1-25 (1991); Edward E. Lawler III \& Susan A. Mohrman, Quality Circles After the Fad, Harv. Bus. Rev., Jan.-Feb. 1985, at $65,65-7$ r. "Joint labor-management committee" refers more broadly to any entity in which managerial and non-managerial employees participate, including committees on which employces serve on an ad hoc and representative basis, rather than on a permanent and participatory basis.

10 These models include flexible specialization, see, e.g., MichaEl J. PIORE \& Charles Sabel, The Second Industrial Divide 28-35 (1984); post-Fordism, see, e.g., Simon Clarke, The Crisis of Fordism or the Crisis of Social Democracy, 83 TELOS 7I, 74-90 (1990); sociotechnical systems, see, e.g., LARRY HirschHORN, BEYOND MECHANIZATION: WORK AND TECHNOLogy in a Postindustrial Age $113-69$ ( 1984 ); the J-firm, see, e.g., Masahiko AOKI, INForMATION, INCENTIVES, AND BARGAINING IN THE JAPANESE ECONOMY 7-43 (1988); and the team organization, see, e.g., Thomas A. Kochan, Harry C. KaTZ \& Robert B. McKersie, The TRANSFORMATION OF AMERICAN INDUSTRIAL RELATIONS 46-6i (I986).

11 "Taylorism" refers to the system of "scientific management" pioneered by industrial engineer Frederick Winslow Taylor at the turn of the century. Its main elements include centralized managerial planning and analysis of production phases; rigorous specification and hierarchical monitoring of the time and motion of narrowly defined work tasks; and incentive payment schemes to motivate workers to perform those tasks. See, e.g., David MONTGOMERY, THE Fall of the House of Labor 214 44 (1987); Daniel Nelson, Frederick W. Taylor aNd THE RISE OF SCIENTIFIC MANAGEMENT 38-46 (1980). 
sifications and work rules. ${ }^{12}$ Although corporate decisionmaking over strategic matters remains centralized, production activity is decentralized and coordinated horizontally among work teams. ${ }^{13}$ Both the empirical question how widespread these innovations are in practice, and the theoretical question whether they mark a distinct break with traditional workplace hierarchies, are highly contested among political economists. 14

The new workplace arrangements have likewise stirred debate over the application of a number of labor law doctrines and over the continued viability of the deeper, purportedly adversarial underpinnings of New Deal labor policy. A primary focus of these debates is section $8(a)(2)$ of the National Labor Relations Act, ${ }^{15}$ which banned the company unionism of the $193{ }^{16}{ }^{16}$ in language spacious enough to jeopardize most of today's experiments in labor-management collaboration. ${ }^{17}$ The decline of company unions in the decade after section

12 In I984, an Organization for Economic Cooperation and Development (OECD) draft report on labor management in the international automobile industry concluded that "[ $t$ ] he strongest general trend is the introduction of group work. . . There is a trend away from 'man-machine relations' towards 'team technological system relations." OECD, THE DEvElopMENT AND Utilisation of Human Resources in the Context of Technological Change and INDUSTRIAL RESTRUCTURING 39 ( 1984 ).

13 The most thoroughgoing of the new organizational forms, exemplified by the Shell chemical plant in Sarnia, Canada, and the joint General Motors-United Auto Workers Saturn plant in Tennessee, are centered around self-managing work teams - formal groups of workers to whom the organization delegates authority for large chunks of the operational and administrative decision-making that is traditionally vested in management. See BARRY BLuEstone \& IRving Bluestone, Negotiating the Future: A Labor Perspective on American Business roi200 (1992) (discussing the Saturn plant); Thomas D. RANKIN, New Forms of Work OrgaNIZATION 60-75 (1990) (describing Shell Sarnia experiment).

${ }^{14}$ Summaries and assessments of the voluminous literature are presented in Richard Hyman, Flexible Specialization: Miracle or Myth? in NeW TEChNOLOGY and Industrial ReLatrons 48, 48-59 (Richard Hyman \& Wolfgang Streeck eds., I988); and Stephen Wood, The Transformation of Work?, in The Transformation OF WORK? SkILl, Flexibility aNd the Labour Process I, 4-28 (Stephen Wood ed., I989).

1529 U.S.C. \& $158(\mathrm{a})(2)$ ( 1988$)$.

16 The typical company union of the I920s and r930s — "works council" or "employee representation plan," as management called it - was established and funded by management and was limited to the employees of a single company. Employees periodically elected representatives from the ranks of the workforce, who generally met with managerial representatives in monthly conferences to discuss workers' grievances, shopfloor operational problems, and, less frequently, wages and benefits. Final authority over all decisions, including grievances, remained with management. Management consent was required for amendment of the constitution or bylaws of the organization. No strike funds were provided. See BUREaU of Labor Statistics, U.S. Dep't of Labor, Bull. No. 634, Characteristics of Company Unions 32-77 (r937).

17 The Taft-Hartley Amendments of 1947 did not change the language of $\S 8(a)(2)$, but did alter the provision's section numbers in the Wagner Act. For simplicity, this Article refers to the pre-1947 provision as $\$ 8(\mathrm{a})(2)$. Section 8(a)(2) provides in part that it is illegal for an employer "to dominate or interfere with the formation or administration of any labor organization or contribute financial or other support to it." NLRA, supra note 3, § r58(a)(2). Section 2(5) defines "labor organization" as "any organization of any kind, or any agency or employee 
8(a)(2) was enacted may obscure, from today's vantage point, the provision's critical effect on American workplace governance and the labor movement since the r93os. The role of the company union was, in fact, the most important substantive issue in the political fight over the drafting and passage of the Wagner Act. ${ }^{18}$ At the time of its enactment, as many as three million workers were organized in company unions, compared to four-and-a-half million members of autonomous unions; and the former were growing faster than the latter. ${ }^{19}$ The NLRA's most basic impact was to encourage outside unionization while erasing the inside union option on which the more progressive managers of the interwar years had pinned their hopes for a stable and effective mode of workplace governance. Section $8(a)(2)$ helped ensure that American labor relations would not follow the path of enterprise unionism and labor-management collaboration that, for example, the Japanese tread in postwar years. ${ }^{20}$ It also discouraged experiments in the kinds of enterprise-based works councils that have been central to German and other European industrial relations. ${ }^{21}$

The recent jurisprudential debates over the ban on collaborative workplace entities have turned on three conceptual axes: adversarialism versus cooperationism, paternalism versus free choice, and labor empowerment versus managerial flexibility. These debates cut across the broader methodological encounter between economic and critical

representation committee or plan, in which emplayees participate and which exists for the purpose, in whole or in part, of dealing with employers concerning grievances, labor disputes, wages, rates of pay, hours of employment, or conditions of work." Id. $\$ 152(5)$. The National Labor Relations Board and the Supreme Court have decided that the labor organization need not "bargain," but need only interact with or make recommendations to management in order to satisfy the "dealing" element of $\S 2(5)$, and that any ongoing employee committee or entity is an "organization." See NLRB v. Cabot Carbon Co., 360 U.S. 203, 212-13, 218 (1959). Section $8(a)(2)$ is therefore implicated in the case of quality circles, joint labor-management committees, and self-managing work teams, as the Board and the circuit courts have frequently recognized - most recently in the Electromation case. See Electromation, Inc., 309 N.L.R.B. No. 163 at 4-9 (Dec. 16, 1992); infra notes 22, 24.

18 See infra pp. 1402-03, ז442-6r. The first of many drafts of the bill in Wagner's Senate office contained only a single substantive provision: a ban on company unions. See Kenneth Casebeer, Drafting Wagner's Act: Leon Keyserling and the Precommittee Drafts of the Labor Disputes Act and the National Labor Relations Act, II INDUS. REL. L.J. 73, 102 (I989) (reprinting the first draft). Milton Handler, General Counsel to the National Labor Board of 1933-34, who drafted the decisional law that was codified in the unfair labor practice provisions of the NLRA, said that the salient substantive problem was "[t]he fight . . . between company unions and outside unions." Milton Handler Oral History 38 (1974) [hereinafter Handler Oral History] (transcript available in Oral History Research Office, Columbia University).

19 See SANFord M. JaCOBY, EMPLOYing BUREaUCRACY 224, 227 (1985).

20 See, e.g., AoKI, supra note ro, at I85-9I (1988); KazUo KoIKE, UNDERSTANDING INDUSTRIAL RELATIONS IN MODERN JAPAN 247-59 (I988).

21 See Ernest R. Burton, Employee Representation 42-43 (1926); Clyde W. Summers, Worker Participation in the U.S. and West Germany: A Comparative Study From an American Perspective, 28 AM. J. CoMP. L. 367, 373-77 (1980). 
theory mentioned above. In one view - to which the National Labor Relations Board has adhered, at least nominally 22 - the new collaborative schemes undermine the adversarial, worker-empowering model of collective bargaining that New Deal labor policy purportedly intended. ${ }^{23}$ In another - reflected in recent circuit court decisions ${ }^{24}$ legal curtailment of these workplace innovations is a paternalistic affront to the Wagner Act's purpose of protecting workers' free choice over modes of dealing with management, and an anachronistic obstacle to efficient labor-management relations. ${ }^{25}$ A third view proposes that adversarial collective bargaining, labor-management cooperation, and free worker choice are compatible, at least within an appropriately reformed legal regime. ${ }^{26}$ In fact, the progressive political entrepre-

22 In a significant ruling, the NLRB recently reaffirmed an objective approach to the application of $\S 8(a)(2)$. See Electromation, Inc., 309 N.L.R.B. No. 163 at 7 (Dec. I6, I992) (finding $\S 8(a)(2)$ violation where joint labor-management committee, established and structured by management, discussed conditions of employment). That is, regardless of workers' subjective satisfaction or dissatisfaction, it is illegal for management to establish, dominate or support labor organizations, understood to include at least representative, ongoing employee entities. (By contrast, the circuit courts have looked to the apparent subjective preferences of the workforce. See infra note 24). However, the Electromation Board also reaffirmed earlier decisions that had stretched the objective approach to accommodate the conventional wisdom that the new cooperative schemes are generally benign. See Electromation, 309 N.L.R.B. No. I63 at 6 (citing General Foods Corp., 231 N.L.R.B. I232 (1977) (characterizing participatory work teams without representative team leaders as work crews performing managerial functions and therefore not "labor organizations" under $\S 2(5)$ ); Mercy-Memorial Hospital Corp., 23I N.L.R.B. I108, I 109 (1977) (finding that a management-created, joint labor-management committee did not "deal[]" with management under $\$ 2(5)$ because the committee had final authority to resolve employee grievances)). The Board's reaffirmation of General Foods leaves open whether self-managing teams with elected or rotating team leaders will be deemed "labor organizations."

${ }^{23}$ See, e.g., Thomas C. Kohler, Models of Worker Participation: The Uncertain Significance of Section 8(a)(2), 27 B.C. L. REv. 499, 515-16 (I986); Wilson McLeod, Labor-Management Cooperation: Competing Visions and Labor's Challenge, I2 INDUS. REL. L.J. 233, 276-80 (I99o); Note, Collective Bargaining as an Industrial System: An Argument Against Judicial Revision of Section 8(a)(2) of the National Labor Relations Act, 96 HARV. L. REv. I662, 1678-80 (1983).

${ }^{24}$ Several circuit courts, candidly rejecting the "adversarial" model of labor relations, have adopted a subjective approach to $\S 8(a)(2)$. They have upheld a variety of managementsupported participatory or representative structures on the ground, inter alia, that there was no apparent worker dissatisfaction with the entities. See, e.g., NLRB v. Streamway Div. of Scott \& Fetzer Co., 691 F.2d 288, 295 (6th Cir. 1982); NLRB v. Northeastern Univ., 601 F.2d 1208, 1213-14 (Ist Cir. I979); Hertzka \& Knowles v. NLRB, 503 F.2d 625, 629-30 (9th Cir. 1974); NLRB v. Newman-Green, Inc., 40I F.2d I, 4 (7th Cir. 1968).

${ }^{25}$ See, e.g., Epstein, supra note 4, at 1391-92; Charles C. Jackson, An Alternative to Unionization and the Wholly Unorganized Shop: A Legal Basis for Sanctioning Joint EmployerEmployee Committees and Increasing Employee Free Choice, 28 SYRACUSE L. REv. 809, 845 (1977); Theodore St. Antoine, The Legal and Economic Implications of Union-Management Cooperation, in Proceedings of the N.Y.U. 4IST ANnual Conference of Labor 8-I (Bruno Stein ed., I988).

${ }^{26}$ See, e.g., PaUl C. Weiler, Governing the WorkPlace 225-306 (I990) (arguing that cooperative schemes should be legalized in non-union workplaces, so long as concurrent legal 
neurs who were most decisive in crafting the model of collective bargaining embodied in the Act were preoccupied with these conceptual relations. That reform elite sought ways to achieve the cooperation and integration of labor and management in large-scale enterprises (and in a polity built on such enterprises) without sacrificing labor to disempowerment and depersonalization.

Wagner's view, it is true, was grounded in the exigent social projects of the mid-r93os: the drive for recovery from the Great Depression and the effort to reconstitute a democratic, capitalist order during the class-fractured emergence of a mass consumption economy. Current approaches to labor-management cooperation arise, by contrast, in a context of heightened international competition and capital mobility, chronic sluggishness in productivity growth, and the rollback of organized labor. Nonetheless, it is worth mapping the salient conceptual and structural assumptions of labor policy of an earlier period of ferment for at least two reasons. First, current policy arguments and legislative interpretations often make historical appeals that are unfaithful to Wagner's fully elaborated "model" of workplace relations. These appeals read back into that model either the adversarial mode of industrial pluralism that hardened during and after World War II or the neoclassical or transaction-cost economic categories of another intellectual universe. ${ }^{27}$ Second, a careful theoretical specification of

reforms protect workers' choice to unionize); cf. Michael C. Harper, Reconciling Collective Bargaining With Employee Supervision of Management, 137 U. PA. L. Rev. 1, 38-75 (1988) (arguing that employee representation on board of directors is compatible with collective bargaining, if proper constraints on conflicts of interests are read into $\S 8(\mathrm{a})(2)) ;$ Karl $\mathrm{E}$. Klare, The Labor-Management Cooperation Debate: $A$ Workplace Democracy Perspective, 23 HaRv. C.R.C.L. L. REv. 39, 60-81 ( 988 ) (endorsing cooperative arrangements in unionized workplaces).

27 This Article assumes that the understanding of a statute articulated by those most responsible for its framing and enactment - particularly its key legislative proponents and the politicalintellectual movements backing them - carries some weight in any appealing interpretive theory, including the pragmatist and radical democratic theories that I find most satisfying. See, e.g., James G. Pope, Republican Moments: The Role of Direct Popular Power in the American Constitutional Order, 139 U. PA. L. Rev. 287, 358-64 (1990); Margaret S. Radin \& Frank Michelman, Pragmatist and Poststructuralist Critical Legal Practice, 139 U. PA. L. Rev. Iorg, 1028-43 (1991). In the case of the Wagner Act, there is also good reason to believe that supporters' elaborate public justifications for the Act coincided with their deeply held, principled beliefs. See infra pp. $\mathrm{I}_{412-27}$, notes 146,245 . While the psychoanalytic question of their "actual" conscious or unconscious motives for supporting the Act is inevitably murky, there are strong normative grounds, rooted in conceptions of deliberative democracy, for basing statutory interpretations on legislators' articulated public-regarding justifications. See, e.g., William N. Eskridge \& Phillip P. Frickey, Statutory Interpretation as Practical Reasoning, 42 STAN. L. REv. 32I, 356-58 (I99o); Pope, supra, at 358-64.

I focus on reconstructing the legal-economic world-view which framed the Act's meaning in the minds of the relevant progressive legislators and their extra-governmental political allies. I do not mean to deny, however, that either the Act's meaning to other propulsive political actors or the causal role of those actors - especially the participants and leaders in the mass labor and political movements of the r93os - may be relevant to statutory interpretation. Cf. Karl 
Wagner's model sheds light on current economic and sociological theories of labor-management cooperation. Some of the most compelling (but more or less maverick) current approaches rest on frameworks similar to Wagner's progressive political economy and are, in fact, usefully supplemented by it.

This Article is therefore archeological and reconstructive. It seeks to uncover the vision of labor-management cooperation of those most responsible for articulating and enacting New Deal labor policy, and to recast that vision in the more explicitly theoretical terms of current economic sociology and anthropology. ${ }^{28}$ Part II links original research on Wagner's circle of political associates with revisionist accounts of interwar political history. It disputes the public-choice view that the political elite responsible for the Wagner Act "sold" policy to the intentional, rent-seeking interests of organized labor or employer associations. Instead, the convergence of two key elements was decisive in the immediate origins of the Wagner Act. The opportunity for such a dramatic legislative initiative was generated by "mass politics" in the form of popular electoral realignment, populist political organization, and mass labor unrest (often outside the compass of organized interest groups and propelled by radical activists and managerial belligerants with no intention of securing legislative reform similar to the Wagner Act). That opportunity was seized by loosely interconnected networks of political-technocratic entrepreneurs driven by progressive ideological commitment and ambition. Fortuitously located at the central nodal point was Robert Wagner, the progressive "powerhouse" of the New Deal legislative program. ${ }^{29}$

E. Klare, Traditional Labor Law Scholarship and the Crisis of Collective Bargaining Law: A Reply to Professor Finkin, 44 MD. L. REv. 731, 754-59 (1985) (claiming that a statute may have alternative meanings within perceptual frames of reference other than that of dominant interpretive theory); Pope, supra, at 360 (arguing that statutes resulting from popular mobilization, such as the Wagner Act, should be given broad, public-regarding interpretation). To the contrary, one historical theme of this Article is the mutual interaction between and partial convergence of reform elites' and workers' understandings of workplace entitlements in the I930s.

28 This Article therefore lays the broad historical and theoretical foundation for a companion Article, in which I apply, elaborate, and empirically assess the (recast) Wagner model in the context of various specific types of labor-management collaboration. The companion Article generates a revised $\S 8(\mathrm{a})(2)$ jurisprudence designed to encourage the most democratic, empowering, and efficient forms of flexible, team-based organizations. See Mark Barenberg, Hegemony and Democracy in the Law of Workplace Cooperation: From Company Unions to Self-Managing Teams (1993) (unpublished manuscript, on file with the author).

${ }^{29}$ Handler Oral History, supra note 18 , at 24. The ideological horizons of Wagner and his circle are unimaginable outside the context of the major social and cultural forces of the I930s; however, their legislative policy was not the sum of vectors of instrumental interest-group pressures and state actors' self-seeking motives. That is, my critique of interest-group instrumentalism does not rule out the Gramscian view that the ideology of political elites (and other social actors) was heavily conditioned by the alignment of social forces. See, e.g., JoSEPH V. Femia, Gramsci's Political Thought 23-50 (I987); infra note 277. 
Part III of this Article then turns to the political ideology and debates of Robert Wagner and the progressive reform currents in which he was immersed. My reconstruction of Wagner's progressivism disputes the conventional assumption that New Deal labor policy rested on an "adversarial" view of labor-management relations. Part III shows that the NLRA was aimed - at least in the minds of the political entrepreneurs who conceived and fought for it - at achieving the legally engineered transformation of large-scale enterprises from low-trust, adversarial organizations into high-trust, cooperative organizations. Wagner's quasi-utopian mission was to "build[] . . . a cooperative order" designed to reintegrate a class-riven society and to replace or at least legitimate asymmetric power relations. ${ }^{30}$ Democratic consent to enterprise and state authority would flow from a regime of egalitarian communication and reason, presided over by the newly fortified administrative state of which Wagner was the principal legislative architect. ${ }^{31}$

Part IV discusses the implications of the political origins and ideological substance of the Wagner Act for the current methodological and substantive debates mentioned above. Addressing three central theoretical questions, ${ }^{32}$ Part IV traces a common theme: instrumental understanding of the behavior of individuals and institutions is enriched by an analysis of the ways that interests, norms, and perceptions are shaped endogenously in institutional practices and discourse.

30 Robert Wagner, Industry and Labor, Address on NBC Radio 6 (Oct. 18, I933) (transcript available in The Robert Wagner Papers, Georgetown University [hereinafter The Wagner Papers], at $600 \mathrm{SF}$ 103, Folder 28).

31 Placing the Act within Wagner's broader progressive vision also brings some clarification to the question, long vexing to labor law adjudicators and commentators, of the relationships and priorities among the Act's multiple purposes. In Wagner's vision, achieving workers' democratic consent and substantive freedom through collective empowerment took absolute precedence over the other important goals of macroeconomic stabilization and growth, but see Kenneth H. Casebeer, Holder of the Pen: An Interview with Leon Keyserling on Drafting the Wagner Act, 42 U. MIAMI L. REV. 285, 295-96 (1987) (arguing that proto-Keynesian policy was primary purpose of Act); industrial peace, but see CHRIstopher L. TOMLINS, The State AND THE UNIONS 318 (1985) (arguing that virtually all proponents of the Act saw the right of selforganization not as an end but only as a means to labor peace); and microeconomic productive or allocative efficiency, but see Stewart J. Schwab, Collective Bargaining and the Coase Theorem, 72 CORNELL L. REv. 245, 254-56 (1987) (equating Congress's assumed primary goal of industrial peace with allocative efficiency). Wagner nonetheless expected that these secondary goals would generally be served as byproducts of achieving his central objective. See infra Part III.

32 The three questions are ( $x$ ) what do the political origins of the Wagner Act teach about the role of legal symbolism and ideological contests in legislative action?; (2) how did Wagner, a committed cooperationist, justify the legislative ban on the foremost managerial models of labor-management collaboration of his day, although other leading progressives, such as Franklin Roosevelt, endorsed such collaboration?; and (3) in Wagner's conception of workplace governance, what is meant by the concept of workplace "cooperation," and what institutional or symbolic mechanisms account for the achievement or failure of cooperation? 
First, as to the puzzle of the political origins of the Wagner Act, the historically contingent interpretive frameworks and subjective interests of key players ${ }^{33}$ played crucial roles. At the same time, as Wagner and his allies fully understood, ${ }^{34}$ the potential symbolic impact of legislative initiatives was a significant endogenous variable in the political process. The intended impact of legislative symbolism, however, was not simply to defuse worker rebellion, but rather to galvanize and focus workers' discontent and sense of entitlement in ways concordant with the political aims of the reforming elite.

Second, with respect to the currently salient question of the purpose of the ban on company unionism, the two leading contemporaneous justifications rested, in different ways, on the assumed social plasticity of worker consciousness. Because, Wagner believed, legalpolitical symbolism would help guide workers' subjective preferences toward the objective "substantive freedom" of full-fledged collective bargaining, management could secure company unionism only by systematic coercion of workers' choice. ${ }^{35}$ A secondary, potentially contradictory, ${ }^{36}$ justification located the danger of company unionism not in its tendency openly to coerce worker choice but rather in its illegitimate reconstruction of workers' perceptions of workplace reality and of their own interests and desires. In Wagner's institutional ideal, company-union-like collaborative structures such as works councils and joint labor-management committees would emerge and operate effectively and non-manipulatively only within the protective shell of independent unionism.

Finally, regarding the theoretical dynamics of workplace cooperation, Wagner and his advisers understood the "labor question" in the same way that contemporary economists model a bargaining game: a central problem is to secure credible commitments to productive effort by workers in exchange for commitments to job security and a fair distributive share by management. In contrast to legal economists' model of the internal labor market, however, Wagner's progressivist model of workplace relations emphasized the group basis of worker

33 They included, in particular, the voluntarist ideology of organized labor; the contested programmatic ideas of elite political entrepreneurs; and the haphazard labor relations philosophies of managerial groups.

34 They had learned a striking lesson from the electrifying effect of $\S 7$ (a) of the National Industrial Recovery Act of 1933, 15 U.S.C. $\S 707$ (a) (1933), on workers' consciousness and behavior.

35 For Wagner, the structural constraints on collective empowerment under company unions blocked workers' substantive freedom. Those constraints included the lack of strike funds, the limits on trans-enterprise or multi-employer bargaining, and the various institutional modes by which company unions suppressed or deflected workers' communication, solidaristic sentiments, and autonomous interest-formation. See infra pp. 1449, I456-59.

36 Potentially contradictory because, as discussed below at pp. 1458, 1482-84, an openly coercive regime is unlikely to succeed at subtle ideological manipulation. 
norms and interests; privileged the distributional contest between labor and management over efficiency maximization; and stressed that norms of fairness, shared interests, and mutual trust could be nurtured by institutional structures cleansed of excessive power disparities. Wagner and his circle recognized that even if hierarchical organization solves certain strategic problems, it also produces cultural and psychic conflict over legitimacy, trust, and resistance - conflict that may significantly influence institutional performance.

Wagner's progressivism and its recent variants thus teach that the relation between power and trust should be a central focus in the current debate over collaborationist labor relations. ${ }^{37}$ The Conclusion comments briefly on the theoretical ambiguities and historical legacy of Wagner's political economy of labor relations.

\section{The Origins of the Wagner Act: The Role of Interest Groups, Mass Politics, and Political EnTrepreneurs}

Some public-choice theorists have been tempted, from a historiographic distance, to deduce that the Wagner Act - including its ban on company unions - was a classic case of legislation designed to promote the rent-seeking interests of an effectively organized interest group. They maintain that the New Deal served its key constituent, organized labor, by encouraging outside unionism and banning the leading rival, company unionism. ${ }^{38}$ The historical evidence does not support such an a priori plausible deduction. ${ }^{39}$ Those accounts reveal several crucial sources of slippage between organized interests and legislative action: first, the ideological contingencies of organized labor, shaped in part by the historical relation between trade unions and the legal system (section III.A); second, the indirect influence on policymaking of macro-structural economic relations, as opposed to the

37 The doctrinal and policy implications are explored in Barenberg, supra note 28.

38 The Act "was procured . . . by the labor movement" acting as an "interest group," according to Richard Posner. Posner, Reading of Statutes, sutpra note 4, at 273. The charge that the Act was nothing but "organized minorities" triumphing over "unorganized majorities" was leveled many times by management representatives in the Congressional hearings. National Labor Relations Board: Hearings on S. 1958 Before Senate Comm. on Educ. and Labor, 74th Cong., Ist Sess. 479, 509, 595-96, 681, 746, 820 (1935) [hereinafter Hearings on S. 1958], reprinted in 2 Legislative HiSTORY OF THE NATIONAL LABOR RELATIONS ACT, 1935, at 1865 , I895, I981-82, 2067, 2132, 2206 (I949) [hereinafter LEGISLATIVE HiSTORY].

39 The historical interpretation offered in Part II draws on original research on Wagner and his network of policy entrepreneurs, but builds on the powerful revisionist literature cited throughout. That original research and revisionist literature, in turn, is at many points (with key exceptions noted below) consistent with the classic narrative accounts of New Deal policy, also cited throughout Part II. Part III offers an original reconstruction of the progressive ideology embodied in the Wagner Act, consistent with Part II's interpretation of the Act's political origins. Part IV assesses the theoretical significance of the political and intellectual histories presented in Parts II and III. 
direct, intentional influence of interest-group deal-making (section II.B); third, the propulsive force of mass electoral politics, populist and radical movements, and relatively disorganized popular unrest (section III.C); fourth, the unpredictability of legislative consequences - including the unanticipated effects of legislation on the preferences and interests of workers - in a time of political desperation and experimentation (section II.D); fifth, the central role of political entrepreneurs, in the form of a rising political-intellectual elite impelled by ideological convictions (section II.E); and, finally, not only the institutional idiosyncracies and fluidity of the political game, but the ideological quirks and personal relations of the key players, especially Robert Wagner and Franklin Roosevelt (section II.F).

\section{A. Organized Labor: Historical Weakness, Ideological Passivity}

At the onset of the New Deal, contemporary observers accurately characterized the American Federation of Labor as "ineffectual flabby, afflicted with the dull pains of moral and physical decline. The big industrialists and conservative politicians are no longer worried by it."40 AFL membership had tumbled from more than five million in I920 to 3.4 million at the peak of prosperity in I929, and, under the impact of the Depression, fell another half million by $19333^{41}$ Organized labor had minimal influence on the Republican Party; neither was "its influence within the Democratic Party . . . substantial, as many party factions mistrusted or even opposed the unions."42 The support of organized labor was irrelevant to FDR's election victory in I932.43 As of early I935, according to historian Thomas Ferguson, "Roosevelt had fairly consistently sided with business against [the AFL], and the federation was increasingly divided and rapidly losing control of its own membership." 44 Nor did unions unaffiliated with

40 Louis Adamic, The Collapse of Organized Labor, I64 HARPER's MONTHLy Mag. I67, I7 I (1932), quoted in Irving Bernstein, The New Deal Collective Bargaining Policy I (I950); see also DAvid Brody, WorKers IN INDUSTRIAL AMERICA 45, 82 (I980) (arguing that "organized labor was an arrested movement" with a "deep sense of impotence").

41 See BERNSTEIN, supra note 40, at 2. One-tenth of the nonagricultural labor force was unionized as of 1933 , a level that had not changed in 30 years. See BRODY, supra note 40 , at 82.

42 David Plotke, The Wagner Act, Again: Politics and Labor, 1935-37, 3 Stud. Am. PoL. DEV. 105, 140 (1989).

43 See Stanley VitToz, New Deal Labor Policy and the American Industrial Economy 78 (1987); Daniel Sipe, A Moment of the State: The Enactment of the National Labor Relations Act, I935, at I Io (I98I) (unpublished Ph.D. dissertation, University of Pennsylvania). Several national union leaders, including John L. Lewis of the Mine Workers, supported the Republican ticket. See id.

44 Thomas Ferguson, Industrial Confict and the Coming of the New Deal: The Triumph of Multinational Liberalism in America, in The RISE aNd FALl OF THE NEW Deal ORder, 1930-1980, at 3, I9 (Steve Fraser \& Gary Gerstle eds., 1989). 
the AFL have the strength to achieve an interest-group power play on the scale of the New Deal revolution in labor policy. ${ }^{45}$

A deep-seated ideological unwillingness to embrace aggressive government intervention in labor relations debilitated organized labor as much as its diminishing size and its failure to achieve prominence in a partisan coalition. Captured in the concept of "labor's voluntarism," the AFL's ambivalence toward an active state was the fruit of decades of governmental attacks on labor. The state's arsenal included judicial exercise of equity powers, the expansive enforcement of antitrust legislation, the nullification of protective labor legislation, and the relentless application of coercive police powers by all levels of government against labor's concerted activity. 46 As late as the spring of I933, while Senator Wagner and others were drafting and debating the national recovery legislation that would form the centerpiece of early New Deal policy, AFL leaders remained "vehemently opposed" to proposals from pro-labor progressives to establish administrative boards empowered to police labor standards. ${ }^{47}$ Even when Wagner's office drafted the landmark section 7 (a) of the National Industrial Recovery Act, enshrining collective organizing and bargaining rights rather than administered labor standards, "the AFL was nowhere to be seen"48 and, in any event, "was in no condition in I933 to have staged such a coup." 49 Nor was organized labor's role any more dynamic when Wagner introduced his I934 Labor Disputes bill. 50 The

45 While the leadership of the emerging industrial unions within and outside the AFL - the Garment Workers, Clothing Workers, and Mine Workers - was more aggressive politically and programmatically, their organizations were particularly hard hit by the economic trends of the rg20s and again by the Depression. They were in no position to exert sufficient pressure to win the Wagner Act. Indeed, the most politically potent unions, the Railroad Brotherhoods, opposed the NLRA. See Sipe, supra note 43 , at III, 175 .

46 See generally William E. Forbath, LAW and the Shaping of the American Labor Movement 37-39, 59-66, 105-18 (1991); Felix Frankfurter \& Nathan Greene, The LABOR INJUNCTION 82-I82 (I930); MONTGOMERY, supra note II, at 271.

${ }^{47}$ Steven S. Fraser, LABOR Will Rule 285-86 (1991). Even the AFL's nominal endorsement of unemployment insurance at its November, 1932 convention required an agonizing effort against the grain of its voluntarist traditions. See Kenneth Casebeer, The Workers' Unemployment Insurance Bill, in LABOR LAW IN AMERICA 231, 238-40 (Christopher Tomlins \& Andrew King eds., I992).

48 FRASER, supra note 47 , at 289 . In the spring of 1933 , the AFL focused its efforts on the Thirty Hours Bill proposed by Senator Hugo Black. Wagner and his adviser, Sumner Slichter, opposed the bill. They believed that such legislation would reduce mass purchasing power and that "economic stability and not the AFL's interests was uppermost." ToMLINS, supra note $3 \mathrm{I}$, at 132; see also BERNSTEIN, supra note 40 , at 30 (recounting same).

49 Donald R. Brand, Corporatism and the Rule of LaW: A Study of the National RECOVERY ADMINISTRATION 266 (1988). However, for a prerevisionist view attributing to the AFL a more significant role in the origins of $\S 7(a)$, see BERNSTEIN, cited above in note 40 , at 32,37 .

so The crucial political elites in a position to transmit or broker interest-group pressure did not believe that organized labor deployed substantial or decisive power. Brains Trusters Rexford 
following year, although his revised Labor Relations bill incorporated changes that in crucial respects cut against the AFL's interests, ${ }^{51}$ the federation left the drafting entirely to Wagner's office. ${ }^{52}$ This is not to suggest that the AFL did not lend lobbying support to Wagner's

Tugwell, Frances Perkins, and Adolph Berle all recognized the relative political impotence of organized labor:

New Dealers in general [did not] have much expectation in 1934 of creative contributions

from labor. In [Labor Secretary] Frances Perkins's experience, the unions never had any ideas of their own; most labor and welfare legislation in her time had been brought about by middle-class reformers in face of labor indifference. [Brains Trust economist Rexford] Tugwell declared that labor 'seems always to be in opposition, to be resisting progress. . . In this they are perhaps worse than most other American groups.' A labor renaissance, he added, appeared unlikely ....

Arthur W. Schlesinger, JR., The Coming of the New Deal 403 (1958). Berle believed that "[t]he theory of the Recovery Administration offered to American labor a chance to pull itself together and achieve a unified policy. This, so far as I am able to discover [as of 1934], American labor groups failed to do .... [W]e over-estimated the potential statesmanship of American labor." Adolph A. Berle, Memorandum Report on the Undenwriting Policy of the National Recovery Administration, in NAviGATING THE RAPIDS, 19I8-1971, at 97, 100 (Beatrice Bishop Berle \& Travis Beal Jacobs eds., 1973).

Leon Keyserling, Wagner's sole legislative aide and the hub of his labor bill drafting team, recalled that AFL representatives "at no time took the initiative" to seek the inclusion of specific provisions in Wagner's labor bills, and asserted more broadly that "organized labor has never been the originator or creator of any of the important progressive economic or social legislation that has benefitted labor." Casebeer, supra note 31, at 329, 349 (quoting Keyserling). Howell Harris confirms that, although the AFL supported Wagner's labor bills, it "played little part in determining what they were, and scarcely understood their detailed implications." Howell Harris, The Snares of Liberalism? Politicians, Bureaucrats, and the Shaping of the Federal Labour Relations Policy in the United States, ca. 1915-47, in SHOP Floor Bargaining AND THE StATE 148, I68 (Steven Tolliday \& Jonathan Zeitlin eds., 1985). Even Irving Bernstein's early history, giving the most AFL-centered account of Wagner's legislation, says that direct AFL pressure behind Wagner's 1934 bill "can be exaggerated" and was secondary to legislators' motivation to address recovery-threatening labor unrest. BERNSTEIN, supra note 40 , at $7 \mathrm{I}-72$. He attributes congressional efforts to force consideration of the 1934 bill against FDR's wishes not to the AFL, but to the initiative of progressive Senators concerned about labor unrest, see id. at 79 , and intimates that the AFL's abandonment of its voluntarist ideology came as a result of the 1934 legislative battle. See id. at 83 .

51 The 1934 bill did not require majority rule. See S. REP. No. I184, 73d Cong., $2 d$ Sess. 27-28, 40, reprinted in I LEGISLATIVE HiSTORY, supra note 38, at I087, I095. Wagner's I935 bill dealt a serious blow to organized labor by barring minority unions. After the AFL unavailingly sought an amendment that would have allowed closed shop agreements with minority unions, "the AFL's endorsement became increasingly strained." ToMLINS, supra note $3 \mathrm{I}$, at I 39 n.115. The I 935 bill also dropped labor's representation on the labor board. See Senate Comm. ON Educ. and LaboR, 74TH CONG., IST SESS., CoMparison OF S. 2926 aNd S. I958, at I (Comm. Print 1935), reprinted in I Legislative HistoRY, supra note 38 , at 1320 . In addition, both the 1934 and 1935 bills included other elements that significantly departed from the AFL agenda, including governmental determination of bargaining units (and therefore union jurisdictional lines) and public, rather than private (i.e. union), enforcement of employee rights. See Tomlins, supra note 3I, at $132-40$.

52 See Casebeer, supra note 31 , at 323, 349. The leading contemporary historian of New Deal labor politics, Steven Fraser, declares bluntly that the Act would have been enacted even without the interest-group support of the AFL. Interview with Steven Fraser in New York, N.Y. (Feb. 7, 1992) (on file at the Harvard Law School Library). 
initiatives or seek advance consultation about the bills' substantive provisions. ${ }^{53}$ But the rent-seeking interests of organized labor clearly were not the driving force behind the initiation, specific content, or passage of his legislation. Nor can the interest-group explanation of the Act's origin be salvaged by the (again a priori reasonable) hypothesis that political elites anticipated that a labor movement enhanced by state power would provide the future interest-group base for their instrumental political purposes. Contemporary observers and historians agree that there simply was no such anticipation. ${ }^{54}$

\section{B. Business: The Contingent Impotence of Well-Organized Interest Groups}

One of the apparent paradoxes of an interest-group perspective on the politics of the New Deal is that the policy of protecting unionization was embraced in the teeth of what at the time was the largest lobbying campaign in American history by business organizations. ${ }^{55}$ Even in the Depression, business associations easily remained the most resource-laden and effectively organized interest groups in the society. The paradox is partially dispelled once policy-making is understood as more than interest groups' (or even the broader electorate's) deliberate buying and state managers' intentional selling of public policy. ${ }^{56}$

A key dimension of New Deal politics is illuminated by a model of the "structural" relation between state policy and private business interests originally formulated by Polish economist Michael Kalecki and elaborated more recently by Fred Block and others. ${ }^{57}$ That model begins with the plausible premise that in a democratic, market economy, political incumbents wish to be reelected. They will therefore attempt to achieve or maintain social prosperity, both as a direct means of maintaining electoral popularity and as a means to sustain tax revenues for popular government spending and enhanced state power. ${ }^{58}$ But in a private economy, prosperity depends on investment

53 See BERNSTEIN, supra note 40 , at 89 (noting that the AFL "firmly supported" the NLRA); id. at IIO-I I (describing AFL efforts in lobbying for, among other things, the NLRA).

${ }^{54}$ See, e.g., SChlesinger; supra note 50, at 403; Casebeer, supra note 31, at 323; Sipe, supra note 43, at 106; supra note 50.

55 See JOSEPh Huthmacher, SENator Robert F. WAgner and the RISE of URbaN LiberalisM I9I (I968); StEPHEN J. SCHEINBERG, EMPLOYERS AND REFoRMERS 245 (1986); VitToz, supra note 43, at 149-50 (stating that the NLRA was "relentlessly" attacked by the National Association of Manufacturers, the U.S. Chamber of Commerce, the prestigious Business Advisory and Planning Council of the Department of Commerce, and, of course, the American Liberty League).

56 On this economic model of policy-making, see below at pp. $1439-40$.

57 See Fred Block, Revising State Theory 51-68 (1987); Michael Kalecki, Selected Essays on the Dynamics of the Capitalist Economy, 1933-I970, AT 139-4I (197I).

58 For an empirical study confirming the importance of economic prosperity for electoral outcomes, see Edward R. Tufte, Political Control of the Economy 9-27 (1978). 
decisions made by private managers of capital, who can be induced to make prosperity-sustaining capital allocation decisions only by government policies consistent with their perception of a favorable investment or business climate. ${ }^{59}$ As a general matter, then, private managers of capital exercise an implicit or "structural" veto over radical reformist policies, for political incumbents know that such policies are likely to induce an unfavorable business climate, an investment slump, and a popularity-damaging economic downturn. Such a veto may operate without any deliberate collective action or political deal-making by managers of private capital. It therefore adds an important determinant of state behavior to the intentionalist, collective-organization core of the public-choice paradigm.

As Block and others note, such a structural veto operates with drastically diminished force in precisely such historical conjunctures as the Great Depression. 60 When business activity is already locked in a low-level equilibrium, radical reforms - such as the Wagner Act, the most dramatic statutory assault on corporate prerogatives in American history - cannot make the climate for investment and consequent macroeconomic performance significantly worse than they already are. Thus, even with direct lobbying by business interest groups at an all-time high, the lapse of the structural veto presented a rare historical opportunity that reform-minded political elites could seize. ${ }^{61}$

This political-science hypothesis is empirically supported by the precise events and motives surrounding Wagner's decision to pursue deeper labor reform in early I934 and FDR's initiation of the "Second New Deal" in the late spring of I935. Conservatives at the time denounced Wagner's early New Deal relief legislation, such as the Federal Emergency Relief Act of 1933, for "increas[ing] the lack of confidence" of business. ${ }^{62}$ But when Wagner unveiled his labor legislation in 1934 , he explicitly rejected "the argument that revival and reform are conflicting objectives and that pursuit of reform at the present time will burden the course of revival" because of business displeasure with reform legislation. ${ }^{63}$ The only alternative to reform

59 See, e.g., Mancur Olson, The Rise and Decinne of Nations: Economic Growth, Stagflation, AND SOCial Rigidities 4-5 (I982).

60 See BLOCK, supra note 57, at 25; Kenneth Finegold \& Theda Skocpol, State, Party, and Industry: From Business Recovery to the Wagner Act in America's New Deal, in Statemaking aNd Social Movements 159, I66-67 (Charles Bright \& Susan Harding eds., 1984); Plotke, supra note 42 , at 116 .

61 The lapse of the structural veto was, of course, reinforced by the ideological de-legitimation of business elites during the Depression. See Schlesinger, supra note 50, at 444; Sipe, supra note 43 , at 108 .

6277 CoNG. REC. 1035-38 (1933) (statement of Sen. Fess).

${ }^{63}$ Robert F. Wagner, Labor Dispute Bill and Other Points in Program for Economic Reform [draft] 3-4 (Apr. I5, 1934) (on file in The Wagner Papers, supra note 30, at 600 SF I03, Folder 3o). 
legislation was "the dismal failure of letting things alone." 64 Rexford Tugwell insisted that from the outset of the New Deal he and the other core members of the original Brains Trust - Adolph Berle and Raymond Moley - had rejected the usually prevailing notion "that business confidence was all-important." 65 In late May of 1935, FDR faced the failure of the two-year experiment in business-dominated corporatism represented by the recovery program of the "First New Deal." The business community's escalating denunciations of FDR were matched by increasingly insistent pleas to radicalize his program from such intimate presidential advisers as Felix Frankfurter. In this

\section{Id. at 4 .}

65 Rexford G. Tugweld, IN Search of Roosevelt 95 (1972). In addition to the shortterm lapse of business's structural veto, secular transformations in the American economy had, by the interwar period, generated clusters of employers less hostile toward collective dealing with workers. Such dealing, however, primarily took the form of "employee representation" or company unionism rather than actual collective bargaining with independent unions. World War I and its aftermath saw the expansion of relatively capital-intensive corporations in industries such as oil, electronics, paper, and tobacco. Some of these corporations were less bellicose in their opposition to collective dealing with employees than were the more labor-intensive firms in sectors such as steel, textiles, and rubber, that had implacably fought organized labor since the late nineteenth century. Thomas Ferguson attributes this attitude to the fact that labor costs were less decisive for the profitability of these emergent firms. See Thomas Ferguson, From Normalcy to New Deal: Industrial Structure, Party Competition, and American Public Policy in the Great Depression, 38 INT'L ORG. 4I, 50-52, 63-64 (1984). Ferguson's theoretical premise is supported by some labor economists. See, e.g., Bruce E. Kaufman, The EcoNOMICS OF LABOR MARKETS AND LABOR RELATIONS 519-20 (2d ed. 1989). Jon Elster and Oliver Williamson, however, argue that capital-intensive firms are more motivated to oppose collective dealing because of their greater vulnerability to workers' collective expropriation of sunk capital. See Jon Elster, The Cement of Society 167 (1989); Oliver E. Williamson, The Economic Institutions of CAPitalism 263 (1985).

At the same time, a smattering of firms tied to the nascent mass consumption market of the rgzos came to believe that the wage-enhancing, mass-market-stabilizing logic of collective dealing was less contradictory to their own interests. See Steve Fraser, The "Labor Question," in The RISE AND FALL OF THE NEW DEAL ORDER, I930-1980, supra note 44, at 55, 60-61. The capital-intensive and mass-consumption firms participated disproportionately in organizations that advocated the "enlightened" company union strategy or full-blown collective bargaining. See FrASER, supra note 47 , at 130-33, 262-64; Ferguson, supra, at 69.

Given the aggressive opposition to the Wagner Act by the business community's most powerful political organizations, however, the more conciliatory behavior of a small number of progressive firms cannot account for the New Deal's affirmative program to encourage collective bargaining. That is, there is little support for the "corporate liberal" theory that the Wagner Act was the work of a far-sighted segment of the business community attempting to save capitalism. But see G. William Domhoff, The Wagner Act and Theories of the State, 6 PoL. POWER \& SOC. THEORY I59, I60-61 (I987) (offering this class segment analysis). Indeed, the corporate leaders of the movement for "enlightened" personnel administration policies, assembled in the elite Special Conference Committee, forged an alliance with the National Association of Manufacturers vigorously to oppose the NLRA. Even the most prominent managerial progressives, such as Henry Dennison, opposed the NLRA because of its ban on company unions. See To Create a National Labor Board, 1934: Hearings on S. 2926 Before the Comm. on Educ. and Labor, 73d Cong., 2d Sess. 400-04 (1934) [hereinafter Hearings on S. 2926] (statement of Henry S. Dennison, industry representative, National Labor Board), reprinled in I LeGisLative HistoRy, supra note 38 , at $434-38$. 
superheated conjuncture, FDR decisively turned against business organizations and, for the first time, announced his support for the labor legislation that Wagner had been doggedly, virtually single-handedly promoting for the previous fifteen months. ${ }^{66}$

\section{Mass Politics: Propulsive, Disruptive, but Indeterminate}

The lapse of business's structural veto was a necessary but, of course, insufficient condition for enacting a program encouraging collective bargaining. A second enabling condition was the maelstrom of mass politics in the I930s, including electoral re-alignment, labor unrest, and populist upsurges. ${ }^{67}$ Even purely intentionalist publicchoice models include the direct influence of popular electoral accountability among the potential sources of policy decisions. ${ }^{68}$ Both Wagner and Roosevelt had been present at the birth of Progressive electoral politics in New York State, where they learned first-hand that populist legislation could yield handsome electoral returns. ${ }^{69}$ The "Al Smith Revolution" that brought urban working classes into the Democratic Party in the late I920s and the national electoral re-alignment of I932 helped set the stage for the Wagner Act. ${ }^{70}$ The decisive electoral event, however, was the I934 national election. Wagner set aside his I934 Labor Disputes bill in June, I934, in the face of FDR's vacillation over labor policy, business's opposition, and the upcoming test of popular support for the New Deal in the November ballot. After the sweeping electoral endorsement, Wagner pushed ahead with an even stronger version of the bill. ${ }^{71}$ The 1934 elections also account in part for FDR's last-minute support for the Labor Relations bill in June, I935, after it passed in the Senate but before the House voted. The President was eager to maintain his alliance with the now-en-

${ }^{66}$ For a further discussion of this transition, see below at pp. I40I-03, 1410-12.

67 See, e.g., Finegold \& Skocpol, supra note 60, at 160-6r; Michael Goldfield, Worker Insurgency, Radical Legislation, and New Deal Labor Legislation, 83 AM. POL. ScI. REv. I257, 1277-78 (I989); Plotke, supra note 42, at II5-II6.

68 The way that electoral accountability modifies interest-group politics has been modelled by Arthur Denzau and Michael Munger, who reach the not-so-startling conclusion that "departures by legislators from their voters' interests are constrained by the strong preferences voters have on some issues, and by the threat of informing and mobilizing public opinion that the news media and potential competitors always represent." Arthur T. Denzau \& Michael C. Munger, Legislators and Interest Groups: How Unorganized Interests Get Represented, 80 AM. POL. SCI. REV. 89, I03 (1986).

${ }^{69}$ See Huthmacher, supra note 55, at 3-37; Robert F. Wesser, A Response to Progressivism: The Democratic Party and New York Politics, rgo2-igir, at 46 (Ig86); $c f$. Irwin Yellowitz, Labor and the Progressive Movement in New York State, i897IgI6, passim (1965) (recounting rise of progressivism in New York).

70 See Kristi ANDERSEN, The Creation of a Democratic Majority, ig28-I936, at 23, 33-38 (1979); Paul Kleppner, Who Voted? The Dynamics of Electoral Turnout, r87oI 980 , at 83-IYI (Ig82).

71 See BERNSTEIN, supra note 40 , at 88. 
larged progressive bloc (especially with its leader, Robert Wagner) in the Congress. ${ }^{72}$ His aim was also to avoid being outflanked on the left by surging populist movements. ${ }^{73}$

One reason for the relative importance of mass politics over interest-group deal-making in the origin of New Deal labor legislation is, of course, the very saliency of the political issues at stake at a moment of extraordinary social crisis. ${ }^{74}$ Such saliency accounts for the heightened mobilization of mass electoral constituencies and of populist political organizations. Even Richard Posner - although he identifies the NLRA as the quintessential interest-group statute - recognizes the theoretical possibility of public-regarding legislation. ${ }^{75}$ Such issuesaliency and attendant mass mobilization offer one explanation for the relative down-grading of interest-group politics - and account for why the very legislation assumed by some to be the prototype of private rent-seeking is taken by others as the paradigm of the "popular republicanist moment." 76

As important as direct electoral and political mobilization, however, were indirect mechanisms of mass influence on policy, again operating in part through political incumbents' motivation to secure economic growth. ${ }^{77}$ Roosevelt and Wagner, in particular, were highly sensitive to the perceived threat to recovery posed by mass labor unrest. ${ }^{78}$ This instrumental motive was reinforced by - indeed, was secondary to - Wagner's deep ideological commitment to an integrationist and cooperationist vision of class relations. That vision was threatened by the spiral of managerial intransigence and the growth of the radical organizations that widely led worker discontent and militancy, especially in the massive strike wave of the summer of 1934. ${ }^{79}$ This represents yet another way in which the substance of

72 See VitToz, supra note 43, at $147-48$.

73 See alan Brinkley, Voices of Protest: Huey long, Father Coughlin and the GREAT DEPRESSION 246-48 (I983).

74 See Barbara Sinclair, Congressional Realignment, 1925-1978, at 35 (xg82).

75 See Posner, Reading of Statutes, supra note 4, at 269-7I, 273.

76 Pope, supra note 27 , at $310-13,362$ (1990). My view is closer to Pope's, although the pivotal role of the political elite takes the origin of the Wagner Act a fair distance from the face-to-face, dialogic politics of classic republicanism.

7 Against the backdrop of the Depression, political incumbents were, unsurprisingly, obsessed with the success of the regime's recovery program. See SCHLESINGER, supra note 50, at 402.

78 See, e.g., Peter H. Irons, The New Deal Lawyers 204 (1982); VitToz, supra note 43, at I34-43; Robert F. Wagner, Company Unions: $A$ Vast Industrial Issue, N.Y. TIMEs, Mar. II, I934, § I9, at I.

79 On Wagner's integrationist vision, see below at pp. I418-22, 1427-30. The three largest strikes of the summer of 1934 were led by radical organizations: the San Francisco general strike by the Communist Party, the Toledo Autolite strike by the American Workers Party, and the Minneapolis Teamsters' strike by the Socialist Workers Party. See IRving BernSTEIN, TURBULENT Years 2I 7-35I (I969). 
New Deal labor policy was not the intentional outcome of group deals. In respectively exacerbating and leading worker unrest, employers and radical organizations had no intent to achieve, and in fact opposed, the kind of legislative response that their actions helped produce. ${ }^{80}$

Although Roosevelt's and Wagner's desire to relieve the sources of labor unrest was unflagging, the pursuit of that policy goal was contingent and shifting. Both the broad contours and the details of the new labor policy turned decisively on the programmatic experience and contests among political entrepreneurs well-positioned to manipulate state power. The experience of the National Recovery Administration labor boards of I933 to I935 was particularly salient. That experience taught Wagner and his circle critical lessons about company unionism and the effects of novel legal initiatives on workers' subjective interests, perceptions, and behavior.

\section{The Crucible of the NLRA: The NRA Labor Boards and "the Education of Senator Wagner"81}

In Senate debates on his I934 Labor Disputes bill, Wagner stated accurately, "[e]very one of its provisions is addressed to specific evils that have become abundantly manifest during the Io months' experience of the [Wagner-chaired] National Labor Board." 82 The unfair labor practice provisions at the core of Wagner's bill essentially codified the specific employer duties, freshly minted by that Board, to refrain from interference with and coercion of workers' collective organizing and bargaining. ${ }^{83}$

The administrative gestation of the Wagner Act was unexpected. Section 7 (a) of the Recovery Act was intended to diminish the number of recovery-threatening strikes. ${ }^{84}$ Its symbolic legitimation of workers' collective action had, in the face of continued employer resistance to

${ }^{80}$ See, e.g., Plotke, supra note 42 , at $\mathrm{II}_{3}-\mathrm{I}_{4}$ (describing Communist Party opposition to NLRA).

81 The NRA labor boards "completed the education of Senator Wagner in the realities of American industrial relations and employer behaviour." Harris, supra note 50, at 166.

8278 CONG. REC. I2,OI8 (1934).

83 The General Counsel to the NLB, Milton Handler, saw the Board's task as the authorship - "writing on a clean page" - of a "common law of labor relations." Handler Oral History, supra note 18 , at 14,18 . Handler recalled:

I don't believe the job [of drafting the Wagner Act] could have been done in the summer of $I 933$ when the [National Labor] Board was established. . . . So . . . we had to learn through experience what were the principal devices which impeded organizational activity, how far you could reasonably go in imposing obligations on the employer to bargain collectively.

Id. at i9-20. See also James A. Gross, The Making of the National Labor Relations BOARD 67 (I974) ("'The I934 bill] reflected in [its] details the agony of the Labor Board.'") (quoting Philip Levy, NLB staff).

${ }^{84}$ See IRONS, supra note 78 , at 204. 
unionization, precisely the opposite effect. ${ }^{85}$ As a result, section 7 (a) led to a degree of federal administrative intervention that its drafters and enactors simply had not foreseen.

The National Labor Board, jerry-built by the White House to respond to this wave of labor unrest, ${ }^{86}$ failed to turn back the tides of worker rebellion and of employer opposition to unionism. ${ }^{87}$ But the Board's failure persuaded Wagner and the other officers of the NLB (and of its successor, the old NLRB) that more thoroughgoing labor reform was required. 88 Their frustration with the implementation of section 7 (a) focused on two broad failings, one remedial and one substantive, that decisively shaped Wagner's labor bill. ${ }^{89}$ First, the NRA labor boards were not equipped with enforcement authority. After four months of successfully eliciting voluntary settlements in a string of "easy" cases, the NLB ran into a credibility-shattering wall of willful employer noncompliance in the high-visibility cases of Budd Manufacturing and Weirton Steel. ${ }^{90}$

Second, and crucial to understanding the origins of section 8(a)(2), Wagner and his circle became increasingly committed to the organic solidarity of autonomous unionism and exclusive representation after they confronted management's deployment of company unionism as a weapon against workers' collective action. The NRA labor boards fought tenaciously against the company unionism and proportional representation condoned by the National Recovery Administration and by FDR himself. ${ }^{91}$ Indeed, the impertinent combativeness of the labor board policy entrepreneurs, assembled by the White House itself,

85 See infra pp. 1435-37.

${ }^{86}$ The NLRA was signed on June $x 6$, I933. "The number of employee-days lost because of strikes tripled between June and September [of 1933], and the calendar year I933 (especially the last half) witnessed the largest number of work stoppages during any twelve-month period since I92 I." ViтTOZ, supra note 43 , at $\mathrm{r} 38$.

${ }^{87}$ See id. at 142.

88 Kenneth Finegold and Theda Skocpol downplay the importance of labor unrest in the origins of the Wagner Act, on the ground that the strike wave peaked in the summer of 1934 and trailed off in 1935, the year the Act was actually passed. See Finegold \& Skocpol, supra note 60 , at $18 \mathrm{I}$. Wagner himself, however, had become personally committed to the legislation during the strike wave of $1933-34$ and, even in 1935 , still feared the recurrence of unrest. See HuTHMACHER, supra note 55, at I92. At the center of Wagner's progressivist world-view was the belief that only collective bargaining could legitimately elicit the acquiescence of workers, at least in the mass production industries. See infra pp. 1423-26.

${ }^{89}$ See Robert F. Wagner, Radio Speech on S. I958, at 6-8 (Mar. 27, 1935) (transcript available in The Wagner Papers, supra note 30 , at 600 SF I03, Folder 33).

90 See Budd Mfg. Co., I N.L.B. 58 (1933). The NLB did not render a reported decision in the Wierton case. On the administrative crisis caused by these two cases, see Gross, cited above in note 83 , at 37-39; and LEWIS L. LORWIN \& ARTHUR WUBNIG, LABOR RELATIONS BOARDS 105-06 (I935).

91 See Interview with Milton Handler, former General Counsel of the NLB, in New York, N.Y. (Oct. 17, 199r) [hereinafter Handler Interview] (on file at the Harvard Law School Library); LORWIN \& WUBNIG, supra note 90, at I12-13, 142-55, 263-72; infra pp. 1454-55. 
attests both to their ideological commitment to progressive labor reform and to their frontline education about the specific modes of employer resistance. ${ }^{92}$ They, and their progressive allies inside and outside government, became the driving force behind the substance and passage of the Wagner Act in $1935 .{ }^{93}$

\section{E. Progressive Policy Entrepreneurs, In and Out of Government ${ }^{94}$}

Wagner's Senate office and the NRA labor boards were the nervecenter of a network of progressive policy entrepreneurs whose ideological commitments and ambitions are not reducible to interest-group reflexes. While Progressivism, understood as a "movement" unified behind a single program, never existed, 95 the programmatic efforts of several loosely connected aggregations of self-identified "progressives" came to fruition in the New Deal years. ${ }^{96}$ This sub-section presents

92 Roosevelt himself ruefully admired the activism of the NRA labor boards. Referring to the key decision of the old NLRB that challenged the proportional-representation/companyunion position of the White House, FDR said, "The Board has been courageous. It certainly took great courage to make that Houde decision." Gross, supra note 83 , at 1oo. See also Harris, supra note 50, at $166-67,184$ (capsulizing the dynamic political role of NRA boards); Sipe, supra note 43 , at $140-45$ (same).

$93 \mathrm{My}$ detailed investigation of the motives and actions of Wagner's particular fraction of elite political entrepreneurs thus confirms and elaborates Plotke's general hypothesis that "in a situation in which capital opposed the Wagner Act and labor did not have enough strength to impose it, both the formulation and implementation of the measure were significantly dependent on what occurred within governmental institutions and political discourse." Plotke, supra note 42, at 134-35; see also BRAND, supra note 49, at 288 (examining the New Deal progressive elite); Harris, supra note 50, at $166-67,184$ (emphasizing the role of state actors). It also illustrates Turner and Supple's broader theoretical claim about "the importance of strategic [governmental] position for the bearer of a particular set of [politically consequential economic] ideas." Turner \& Supple, supra note 2, at 23.

94 The term "policy entrepreneur" usually refers only to governmental actors, particularly legislators. See Eric M. Uslaner, Policy Entrepreneurs and Amateur Democrats in the House of Representatives: Toward a More Party-Oriented Congress?, in LegISLATIVE REFoRM IO5 (Leroy N. Rieselbach ed., 1978). It is intended to capture one sense in which legislators are relatively free from interest-group instrumentalism. See Daniel Shaviro, Beyond Public Choice and Public Interest: A Study of the Legislative Process as Illustrated by Tax Legislation in the I980s, I39 U. PA. L. REV. I, 93-94 (I990). I use the concept to refer more broadly to a network of policy reformers inside and outside government, while recognizing that the signifcance of such a network for legislative outcomes depends ultimately on its linkage with legislators.

95 See James T. Kloppenberg, Uncertain Victory: Social Democracy and ProgresSIVISM IN EUROpEAN AND AMERICAN Thought, I870-1920, at 3II, 3II n.27, 362-63 (1986) (identifying Progressive factions); Peter G. Filene, An Obituary for "The Progressive Movement," 22 AM. Q. 20, 20-24 (1970).

96 The Wagner Papers are studded with the Senator's self-description as a "progressive" reformer. See, e.g., Robert F. Wagner, Talk at Woman's Trade Union League in (May 6, 1936) (on file in The Wagner Papers, supra note 30, at 600 SF 103, Folder 37); Robert F. Wagner, Draft Article for Chicago Daily News 4 (Sept. 26, r932) (on file in The Wagner Papers, supra 
a highly schematized map of the relevant entrepreneurs' ideological and institutional locations and linkages. Part III below discusses the various substantive philosophical and programmatic currents among these reformers, their particular blend in Wagner's philosophy, and their decisive effect on the passage and content of Wagner's legislation.

Because of Robert Wagner's early immersion in New York State reform politics, he was, by the time he took his United States Senate seat in I927, already on "intimate terms" with many of "the hard core of Progressive Era social reformers" who had continued their reform efforts into the $1920{ }^{97}$ His first legislative aide, Simon Rifkind, established formal ongoing communication with "a nationwide network of professional and academic social scientists," numbering approximately 250 , who were regularly mobilized for consultation and lobbying in the legislative battles that Wagner spearheaded. ${ }^{98}$ Contemporary observers recognized Wagner as the first legislator to draw so systematically on the newly consolidated social sciences of the interwar period. 99

Wagner's larger network of personal and organizational allies is illustrated (though that network's full concatenation is by no means exhausted) by the team of legal and social science advocates in Wag-

note 30, at $600 \mathrm{SF}$ 103, Folder 25); Robert F. Wagner, The Government and Labor Relations, CBS Radio Address 2 (June 4, 1937) (on file in The Wagner Papers, supra note 30, at $600 \mathrm{SF}$ I03, Folder 38). Although FDR self-consciously adopted the term "liberalism" for his brand of reform politics, he, Tugwell, and Wagner still "called themselves progressives," and FDR predicted in 1932 that his presidency would reshape the Democratic Party into a "Progressive party." Rexford G. Tugwell, The Brains Trust 411 (1968).

For the richly documented view - confirmed by this Article's exploration of Wagner's particular network of policy entrepreneurs - that the ideology of New Deal reform generally may be understood as an outgrowth of certain currents of progressivism, see BRAND, cited above in note 49, at 6I-69; FrASER, cited above in note 47, at 4-12, 77-348; and Plotke, cited above in note 42 , at $120-35$. For an earlier, contrary view and debates about the genealogy of reformist elites, see Richard Hofstadter, The Age of Reform: From BRyan to F.D.R. 302-80 (I955); and Otis Graham, AN ENCORE FOR Reform: The Old Progressives and THE NEW DEAL I79-8I (I967).

97 HuTHMaCHER, supra note 55, at 58.

98 John Brooks, Advocate: Simon Hirsch Rifkind, NEw YoRkER, May 23, 1983, at 46, 56; see also Interview with Simon Rifkind, in New York, N.Y. (Oct. 17, 1991) [hereinafter Rifkind Interview] (on file at the Harvard Law School Library) (expressing same idea).

${ }^{99} \mathrm{He}$ quickly became known to the Washington press corps as "the regular spokesman at the Capitol for scientific and progressive economists." HUTHMACHER, supra note 55, at 76. Isador Lubin, himself a leading progressive economist, see infra pp. 1405-06, was greatly impressed by Wagner's relentless search for "the best" social scientists to call to Washington for advice on specific questions of industrial and labor policy. Isador Lubin Oral History 43 (I957) [hereinafter Lubin Oral History] (transcript available in Oral History Research Office, Columbia University); $c f$. Edward A. PURcell, JR., The CRISIS of Democratic Theory: Scientific NATURAlism AND the Problem of VALUE 95-114 (1973) (describing interwar social science and its relation to progressive politics); DOROTHY ROSS, THE ORIGINS OF AMERICAN Social SCIENCE I43-257 (I99I) (same). 
ner's campaign against the labor injunction in the late I920s; his Senate aides and inner-circle advisers; the members and staff of the NRA labor boards; and the small groups that Wagner led in drafting his key recovery and labor bills. First, Wagner's inner circle of economic advisers included the day's preeminent institutionalist economists - particularly labor economists ${ }^{100}$ - many of whom were leading students of the pioneering progressive institutionalists, Thorstein Veblen, Simon Patten, and John Commons. By way of example, Isador Lubin, Wagner's closest economic adviser after I928, was Thorstein Veblen's most intimate protege. ${ }^{101}$ A staff economist at the new progressive think-tank, the Brookings Institution, ${ }^{102}$ Lubin was a leading proponent of collectivist planning within the National Progressive Conference, ${ }^{103}$ and a close associate of several members of

100 In addition to the three economists discussed in this paragraph, Wagner's advisers included such leading institutionalists as Sumner Slichter, Leo Wolman, Jett Lauck, and Paul Douglas. See 5 Joseph Dorfman, The Economic Mind in American Civilization 520-44 (1959); W. JetT LAUCK, Political aNd INDUSTRIAL Democracy, I776-r926, at 79-9I (1926); Paul McNulty, The Origins and Development of Labor Economics: A Chapter in THE History OF SOCIAL THOUGHT I50-59, I80-97 (1980).

101 See Dorfman, supra note 100, at 534-35; Lubin Oral History, supra note 99, at 12-13. Lubin was a graduate student of Veblen's at the University of Missouri and for a time lived with and provided personal care for Veblen and his wife. Lubin recruited Veblen to a wartime post in the Food Administration, but both were fired after they submitted a report recommending a conciliatory policy toward agricultural workers affiliated with the Industrial Workers of the World. See Isador Lubin, Recollections of Veblen, in THORSTEIN VebLEN 13I, 138-42 (Carlton C. Qualey ed., rg68).

102 Harold Moulton, the Brookings Institution's president, and Meyer Jacobstein, a Brookings staff economist and close friend of Wagner's, were key members of Wagner's drafting group for the National Industrial Recovery Act. See Huthmacher, supra note 55, at I46. The core of Wagner's Recovery Act originated from a plan circulated by Moulton and Jacobstein. See id. Jacobstein was a particularly influential adviser of Wagner's during the framing of the NIRA. See Rifkind Interview, supra note 98.

103 In I93I, Lubin was a member of the committee on unemployment and industrial stabilization established by the National Progressive Conference. Lubin's colleagues on the committee included such progressive luminaries and Wagner associates as Tugwell, Jacobstein, Leo Wolman, George Soule (editor of the house organ of progressivism, The Nerw Republic), Edwin Smith (adviser to corporate progressives Henry Dennison and Edward Filene of the Twentieth Century Fund, and, later, member of the old NLRB), Sidney Hillman (president of the Amalgamated Clothing Workers), and Florence Kelley (secretary of the Consumers' League, another loyal ally of Wagner's, in both his New York State and New Deal reform campaigns). See Fraser, supra note 47 , at 281-82; HuthMaCher, supra note 55 , at 39, 73; R. AlaN LAwSON, THE FAILURE OF INDEPENDENT LIBERALISM, I930-I94I, at 67-74 (I97I). Senator La Follette, a close progressive Senate ally of Wagner's, drew on the work of that committee in formulating a bill to establish a National Economic Council for purposes of economic planning. The hearings on the bill, in which Lubin served as La Follette's aide, were a significant forum in which progressive proponents of democratic economic planning, such as Frankfurter, Hillman, and Lubin, began their political war against the recovery plans promoted by business leaders. That battle was ultimately settled by the Wagner-drafted-and-sponsored Recovery Act of 1933, whose $\S 7$ (a) sparked more thoroughgoing labor law reform. See FrASER, supra note 47, at 280-82; 
the Senate's progressive bloc. Leon Keyserling, Wagner's Senate aide and economic adviser from I 933 to $1938,{ }^{104}$ was a protege of the New Deal's "economic counsellor at large,"105 institutionalist Rexford Tugwell. Tugwell, in turn, owed heavy intellectual debts to Veblen, Patten, and the avatar of progressive philosophy and political action, John Dewey. ${ }^{106}$ William Leiserson - who was Commons's most energetic disciple in the academic and practical worlds of industrial relations ${ }^{107}$ - worked closely with Wagner during the crucial educative months of the NLB's operation, participated in the drafting team for Wagner's I934 labor bill, testified on behalf of it and the I935 bill, and helped orchestrate the Twentieth Century Fund's influential campaign in support of the NLRA. ${ }^{108}$ In the I920s, Leiserson was a central figure in refining the progressive institutionalist model of collective bargaining as a form of workplace constitutional democracy, a key metaphor in Wagner's understanding and appeals for passage of the NLRA. ${ }^{109}$

Stuart Kidd, Collectivist Intellectuals and the Ideal of National Economic Planning, 1920-33, in Nothing Else to Fear: New Perspectives on America in the Thirties 15, 26-33 (Stephen Baskerville \& Ralph Willett eds., r985) [hereinafter NEw PERspectrves]; Lubin Oral History, supra note 99 , at 50.

104 Wagner hired Keyserling away from Jerome Frank's legal staff at the Agricultural Adjustment Administration after the Senator witnessed Keyserling's commitment to collective bargaining in meetings between Frank and Wagner and their staffs during the drafting of the Recovery Act. See Casebeer, supra note 31, at 296, 314; Leon Keyserling, The Wagner Act: Its Origin and Current Significance, 29 GEO. WASH. L. REv. 199, 200 (1960).

105 Stephen Baskerville, Cutting Loose from Prejudice: Economists and the Great Depression, in New PERSPECTIVES, supra note 103, at 259, 277.

106 See, e.g., BrAND, supra note 49, at 77; Kidd, supra note I03, at 20.

107 See J. Michael Eisner, William Morris Leiserson: A Blography 12 (1967). Before the First World War, Leiserson, as Wisconsin's Deputy Industrial Commissioner, established public employment offices which served as a model for Wagner-supported New York State legislation of the Igros and Wagner's federal legislation of the late Igzos. During the war, Leiserson advised Wagner's fellow New York reform democrat, Franklin Roosevelt, on labor matters, and began a close association with another future Wagner associate, Sidney Hillman of the ACW, whose "new unionism" of the 1920s became a model for the New Deal labor policy. See id. at 12, 93; FRASER, supra note 47, at I30-3I, 330-32.

${ }^{108}$ See BERnSteIN, supra note 40 , at 63; FrASER, supra note 47 , at 330-31. Leiserson was particularly important in shaping the crucial policy banning company unions. See Casebeer, supra note 31, at 335. On the role of the Twentieth Century Fund in supporting the Wagner Act, see TOMLINS, cited above in note 3I, at 131 , 3I8; and REPORT OF THE SPECIAL COMMITTEE ON THE Government and Labor of the Twentieth Century Fund 2 (1935) (on file at The Wagner Papers, supra note 30 , at $700 \mathrm{LA} 7 \mathrm{I} 7$, Folder 36).

${ }^{109}$ See William Leiserson, Constitutional Government in American Industries, 12 AM. EcoN. REv. (SUPP) 56, 60-66 (1922); infra section III.D. Leiserson opened channels to two influential clusters of progressive technocrats: the industrial engineers, managers, and academics affiliated with the Taylor Society, and the corporate liberals and social scientists of the Twentieth Century Fund. Both of those organizations played important entrepreneurial roles in the passage of the Wagner Act. See supra note 108; infra pp. 1408-09, 1428-29. 
Second, the legal reformers who staffed the NRA labor boards including Milton Handler, ${ }^{110}$ Philip Levy, ${ }^{11}$ Thomas Emerson, ${ }^{112}$ and Paul Herzog ${ }^{113}$ - were young exemplars of two closely related currents of influential legal activists. The two converged both in the long-term construction of the labor relations model ultimately embodied in the Wagner Act, and in the decisive short-term crafting and passage of the Act. The first current was "the emerging mandarinate of the regulatory state," led by the quintessential progressive political entrepreneurs Felix Frankfurter and Louis Brandeis. ${ }^{114}$ In the economic emergency of the I930s, many proponents of an expanded administrative state looked back to the First World War administrative experience - in which Frankfurter played a central role ${ }^{115}$ - as a model both for the quasi-corporatist Recovery Act of I933 and the administered collective bargaining of the Labor Act of 1935.116 There is a certain historical symmetry in the fact that Frankfurter, progenitor of the wartime model of the Igros, helped convince FDR to give

110 Beginning in 1932, Columbia law professor Milton Handler advised Wagner on the antitrust aspects of economic planning. Later, as General Counsel to the NLB, working closely with Wagner, Handler helped shape the Senator's bedrock commitment to collective bargaining into a viable administrative system of rules and procedures. Handler directed a legal team that fortified the NLB's substantive rules protecting collective bargaining and countered the influence of the less aggressively reformist Labor Department on Wagner's labor bill. See Huthmacher, supra note 55, at 145; Handler Interview, supra note 91. But see Casebeer, supra note 3I, at 307 (downplaying the importance of the staff of NRA boards); Handler's and Irons's claim about the importance of the NRA boards' staff is plausible in light of the fact that these boards' decisions formed the substantive core of the NLRA. See IRONS, supra note 78, at 227-28.

111 Levy, a former student of Handler's, contributed substantially to Wagner's I934 and I935 bills (and later succeeded Keyserling as Wagner's Senate aide). See Gross, supra note 83, at I3I-45.

112 Emerson, a product of the legal realists at Yale Law School, "worked over [Wagner's I934 bill] in great detail" while sharing a house with Keyserling and other New Deal lawyers. See IRONS, supra note 78 , at 226 .

${ }^{113}$ Herzog, while still a law student, served as NLB assistant secretary under Leiserson, and later became chair of the post-Wagner Act NLRB. See GROsS, supra note 83, at I9.

114 Irons, supra note 78, at 7. See generally BrUCE MURPHY, The Brandeis/FrankFURTER CONNECTION 98-275 (1982) (discussing the political influence of Brandeis and Frankfurter). Other important Wagner advisers and allies from this current of administrative-state activists included Adolph Berle, Gardiner Means, Joseph Chamberlain, and Lloyd Garrison.

See Handler Interview, supra note 91.

115 Frankfurter had been at the center of labor administration and policy as chairman of the War Labor Policies Board and a principal civilian adviser to Newton Baker, Secretary of the War Department.

116 See William Leuchtenberg, The New Deal and the Analogue of War, in Change AND Continuity In Twentieth-Century AMERICA 8I, II 7-22 (John Braeman, Robert H. Bremner \& Everett Walters eds., I964); Gerald D. Nash, Franklin D. Roosevelt and Labor: The World War I Origins of Early New Deal Policy, I LaB. Hist. 39, 52 (1960). But cf. VItToz, supre note 43 , at 77 (noting that New Deal labor policy was more of a positive macro-economic program than was the reactive mediation policy of World War One.) 
decisive support to its I930s reincarnation in the Wagner Act. ${ }^{117}$ Meanwhile, Frankfurter's mentor and political co-conspirator into the I930s, Brandeis, was intimately involved in the origins of the key institutional bridge between the wartime labor machinery and its New Deal variant: the "new unionism" of the needle trades. ${ }^{118}$ Brandeis's was the most influential public voice urging the marriage of labor progressivism and scientific management in the I9IOS and I920S. ${ }^{119}$ That union, blessed by the Taylor Society and Robert Wagner after the war, had crucial consequences for the conception of labor-man-

117 See, e.g., Huthmacher, supra note 55, at I97-98; Michael E. ParRish, Felix FrankFURTER AND HIS TIMES: THE REFORM YEARS 243-46 (1982). Frankfurter was an active supporter of Wagner's overall proto-Keynesian program, including its collective bargaining and public works components. See Stephen Baskerville, Frankfurter, Keynes, and the Fight for Public Works, 1932-1935, 9 MD. HiSTORIAN 1, 4 (1978); Felix Frankfurter, What We Confront in American Life, SURV. GRAPHIC, Apr. I933, at 133, 133-35.

The key language of the Wagner Act's preamble and central substantive provisions $-\S \S 7$ \& 8(I) - was derived from the Frankfurter-drafted policy statement of the Norris-LaGuardia Act. See Robert Gorman \& Matthew Finkin, The Individual and the Requirement of "Concert" Under the National Labor Relations Act, I30 U. PA. L. Rev. 286, 333-35, 337-38 (1981). The Norris-LaGuardia policy statement was first incorporated in $\S 7$ (a) of the NIRA of 1933 , and then redeployed in the NLRA. See National Industrial Recovery: Hearings on H.R. 5664 Before the House Comm. on Ways and Means, 73d Cong., ist Sess. Ir7 (1933) (statement of William Green). Frankfurter's Norris-LaGuardia language, in turn, was similar to that of the earlier Railway Labor Act of 1926, ch. 347, \& 2, Third, 44 Stat. 577 (1926) (codified as amended at 45 U.S.C. \$ 152 , Third), drafted principally by longtime labor progressive and legal activist Donald Richberg, who collaborated with Frankfurter and others in drafting the Norris-LaGuardia Act. See Irving Bernstein, The Lean Years 397-403 (I960); Forbath, supra note 46, at 163-64; Daniel Ernst, The Yellow-Dog Contract and Liberal Reform, 1917-1932, 30 LAB. HIST. 25I, 27 I-72 (I989).

118 Brandeis's creative role in the Igro strike negotiations in the New York garment industry helped forge the landmark "Protocol" under which Brandeis himself served as impartial umpire. See Fraser, supra note 47, at 78; Philippa Strum, Louis D. Brandeis $176-77$ (1984). The Protocol was an important step in developing the model of a "lawful, constitutional framework of labor relations" that was central to the garment trades in the rgzos and to the Wagner Act scheme itself. Steve Fraser, Dress Rehearsal for the New Deal: Shop-Floor Insurgents, Political Elites, and Industrial Democracy in the Amalgamated Clothing Workers, in Worring-Class AMERICA 212, 217 (Michael H. Frisch \& Daniel J. Walkowitz eds., 1983).

${ }^{119}$ See, e.g., Louis Brandeis, Efficiency by Consent: To Secure Its Active Cooperation Labor Must Be Consulted and Convinced in Regard to Changes, 55 InDus. MGMT. 108, 108-09 (1918). The most important event that propelled scientific management into popular consciousness and linked it firmly with progressivism - was Brandeis's invocation of scientific management in his well-publicized condemnation of the Eastern railroad trunk lines in the ICC rate case of I9I0-II. See Louis D. Brandeis, Scientific Management and the RaIlroads (I91 I) (reprinting Brandeis's brief to the ICC); SAMUEL HABER, EFFICIENCY AND UPLIFT: SCIENTIFIC Management In THe Progressive ERA-I890-I920, 53-6r, 77, 80-82 (1964); Strum, stipra note II8, at I6I-65. Frankfurter also actively supported the combination of unionism and Taylorism. See, e.g., Felix Frankfurter, Industrial Relations: I. Some Noteworthy Recent Developments, 4 BULL. TAYLOR SOc'Y 12, 12-16 (1919). Keyserling, the hub of Wagner's NLRA drafting team, acknowledged that the theory of collective bargaining that informed his work on the Act owed a large intellectual debt to Brandeis. See Casebeer, supra note 3I, at 320. 
agement cooperation animating New Deal labor legislation. ${ }^{120}$ The Taylor Society, a progressive "oasis" in the I920s for future innercircle New Dealers, ${ }^{121}$ also lent its organizational muscle to the passage of the legislation. ${ }^{122}$

The legal realist movement was the second current of progressive legal activism that substantially influenced the Wagner Act.123 In addition to the younger realist-influenced staff of the NRA boards and of Wagner's Senate office, such eminent academicians as Robert Hale ${ }^{124}$ and Herman Oliphant ${ }^{125}$ of Columbia and Jerome Frank ${ }^{126}$ and Thurman Arnold ${ }^{127}$ of Yale collaborated with Wagner at a number of stages, one of which was legislatively and historically decisive. ${ }^{128}$ In a triumphant speech in 1937 - five days after the Supreme Court ended two years of paralyzing corporate attacks on the constitutionality of the NLRA - Wagner explained and extolled the influence of legal realism on the Act's origin and substance. ${ }^{129}$

A final category of progressives instrumental in Wagner's legislative program was a miscellany of industrial relations "practitioners," including enlightened managers such as Meyer Jacobstein and Daniel Willard; Taylorist engineers such as Otto Beyer and Morris Cooke; and efficiency-minded labor bureaucrats and activists such as Sidney Hillman. These practitioners were especially important in imple-

120 See infra pp. 1416, 1428-30.

121 HABER, supra note II9, at 46; see also FRASER, supra note 47, at 268-70 (recounting development of Taylor Society); EdWIN T. LAYToN, JR., The Revolt of the ENGINEERS I44-45 (1986) (same).

122 See, e.g., Letter from Francis Biddle to Robert Wagner I (March I4, 1935) (on file in The Wagner Papers, supra note 30, at 700 LA 717, Folder 36).

${ }^{123}$ Even as a New York State judge in the Ig20s, Wagner showed the influence of the new legal pragmatism. See HUTHMACHER, supra note 55, at 45-49.

${ }^{124}$ In Senate hearings, Hale, an early and active proponent of the Labor Act, voiced quintessential realist arguments about the pervasiveness of relations of power and coercion in the labor market, which were echoed throughout Wagner's own rhetorical appeals for the Act's passage. See Hearings on S. 2926, supra note 65, at 50-58 (statement of Prof. Robert L. Hale), reprinted in I LEgislative. HistoRY, supra note 38 , at 80-88; 78 CoNG. REC. 3679 (1974) (statement of Sen. Wagner), reprinted in I Legislative History, supra note 38 , at 20 ; Casebeer, supra note $3 \mathrm{I}$, at 304 .

125 Wagner, Oliphant, and Hale collaborated on a brief, which was published by the Workers Education Bureau and widely circulated among labor progressives, that combined institutionalist and realist arguments against the yellow-dog injunction. See INTERBOROUGH RAPID TRANSIT Company Against William Green, et al., Brief for Defendants (1928) [hereinafter Wagner Brief]; HuthMACHER, supra note 55, at 65; infra note 230 .

126 The "vigilance" of Frank, Keyserling, and Wagner was instrumental in ensuring the inclusion of $\S 7(\mathrm{a})$, which decisively set in train the events leading to the Wagner Act. ScHLESINGER, supra note 50, at 99; see also BERNSTEIN, supra note 40, at 33 (confirming Frank's role).

127 Arnold advised Wagner on labor and other matters in this period. See Rifkind Interview, supra note 98 .

128 See supra note 126.

129 See Robert F. Wagner, Law and Judges: NLRA One-Sided?, Speech at Yale Law School 2-22 (Apr. 16, r937) (on file in The Wagner Papers, supra note 30, at 600 SF 103, Folder 38). 
menting and defending what became Wagner's model of "cooperative" or "integrationist" collective bargaining, discussed at length below in sections III.E and IV.C.

These various elite progressive strands stretched across an organizational lattice of academic departments, ${ }^{130}$ think tanks and professional associations, ${ }^{131}$ journals, ${ }^{132}$ independent or bipartisan progressive political organizations, ${ }^{133}$ legislatures and public bureaucracies. ${ }^{134}$

\section{F. The Fortuitous Role of "The Key Man in Congress"135}

These channels of progressive influence leading directly or indirectly to Robert Wagner loom as large as they do in the origins of the NLRA because of his extraordinary, historically fortuitous role in the New Deal legislative program. Virtually alone in the Congress, Wagner had an all-consuming commitment to collective bargaining as an integral component of political democracy in the age of mass production. Wagner was the only legislator active in drafting the 1933 Recovery Act, including the labor rights of section $7(\mathrm{a}) ;{ }^{136}$ in drafting

130 These included schools of law, economics, philosophy, social work, industrial relations, and engineering.

${ }^{131}$ The Brookings Institution, the Taylor Society, the Twentieth Century Fund, the Russell Sage Foundation, and the American Association for Labor Legislation were among the most important. Wagner had particularly close ties with the AALL, whose officers included a pantheon of leading progressives. See Robert F. Wagner, Compensation for Transportation Workers, 26 AM. LAB. LEG. REV. I5, I8 (I936) (expressing debt to AALL).

132 Wagner maintained ties with and occasionally contributed to the leading progressive publications, which, in turn, supported his legislative efforts both editorially and through their ancillary organizational links. Wagner had such ties with The New Republic, The Nation, Liberty, Survey Graphic, New Outlook, and other publications. Paul Kellogg, the editor of Survey Graphic and a close associate of Wagner, participated in the Emergency Committee for Federal Public Works that supported Wagner's campaign for countercyclical public works (which culminated in the Recovery Act), mobilized lobbying on behalf of Wagner's labor legislation, and published articles extolling both. See Correspondence Between Paul Kellogg and Robert Wagner (on file in The Wagner Papers, supra note 30, at LE 188, Folder 423). George Soule, editor of The New Republic, was active in the American Association for Labor Legislation and the National Progressive Conference.

133 These included the National Progressive Conference, the League for Independent Political Action, and John Dewey's People's Lobby.

134 Note that these institutional positions are predominantly outside the economic interest groups of the market economy proper. See FrASER, supra note 47, at 266; Sipe, supra note 43, at 54, 167. The theoretical significance of this fact is discussed below at pp. 1433, 1440-42.

135 John Dewey's Peoples Lobby gave Wagner this title in 1932. See HUTHMAcher, supra note 55 , at II8.

136 See Robert F. Himmelberg, The Origins of the National Recovery AdminisTRATION 203-Io (I976). Indeed, Wagner initiated the entire industrial recovery legislation independent of even the White House. When FDR dropped efforts to modify Senator Hugo Black's Thirty Hours Bill and instead supported broader recovery legislation in April, I933, the President himself was "follow[ing] Wagner's lead." Id. at 20 r. 
and promoting his I934 Labor Disputes bill; ${ }^{137}$ and in the fifteenmonth campaign of redrafting and lobbying that culminated in the passage of the I935 Act.138 Many historians have affirmed Arthur Schlesinger's conclusion that Wagner "almost singlehandedly forc[ed] a reluctant administration into a national labor policy."139

What explains Wagner's ultimate success? Wagner had become the main bridge between the two dominant ideological blocs in the Democratic Senatorial contingent - the progressive insurgents, whose ranks were swollen by the I934 election, and the "regulars" - especially as to the issues that became salient after the stock market crash. 140 After I927, he had quickly established himself among both groups as the Senate's unmatched authority on labor and industrial policy. ${ }^{141}$ Equally important, no other legislator had the longstanding personal and political friendship with FDR that gave such pre-eminence to Wagner's legislative role in the New Deal. FDR's resulting dependence on Wagner's legislative leadership, in turn, gave the Senator the leverage against FDR to insist that his labor legislation go forward. ${ }^{142}$ Finally, Wagner's stunning policy entrepreneurship was aided by the "extraordinary openness and confusion of the policymaking and administrative process in the mid-r930s."143 In particular,

137 When Wagner introduced his I934 Labor Disputes bill, he said, accurately, "It reflects my own experience. As to this legislation, I alone am responsible for it." Hearings on S. 2926, supra note 65, at 3 I (statement of Sen. Wagner), reprinted in I LEGISLATIVE HISTORY, supra note 38 , at 43 .

138 Wagner's 1934 and 1935 bills met, at best, indifference from the Labor Department, the National Recovery Administration, the chair of the Senate Education and Labor Committee, and, most importantly, the President. See Irons, supra note 78, at 213; Casebeer, supra note 3I, at 3r3; Leon Keyserling, Why the Wagner Act?, in The WAGner ACT: After Ten Years 5, 6 (Louis G. Silverberg ed., 1945).

139 SCHLESINGER, supra note 50, at 403; see also BERNSTEIN, supra note 40, at 128 (confirming same); VITTOZ, supra note 43 , at I48 (stating that NLRA "was forced to a vote by the sheer tenacity of its chief legislative sponsor"); Harris, supra note 50, at I68 ("Wagner, almost singlehandedly, and against the odds, sustained the campaign for federal labour law reform in I934 and 1935.").

140 See HutHMACHER, supra note 55 , at II8.

141 "In the Senate [in 193 I] only one man had shown a consistent preoccupation with the business cycle, the labor movement, and other issues of industrial society. This was Robert F. Wagner ...." ARThur W. Schlesinger, JR., The CRISIS of the OLd ORder, IgI9-I933, at 224 (1957); see also id. at II3 (noting that Francis Perkins "was 'amazed' at the deference that New York's junior senator already enjoyed at the Capitol" in I929); HUTHMACHER, supra note 55, at 118 (noting that even conservative Democrats "came to trust his knowledge and judgment on industrial problems"). The deference shown to Wagner's expertise throughout the protracted NLRA legislative proceedings is undeniable. According to Handler, "[t]here was absolutely no chance of any legislation going through in the labor field without [Wagner's] endorsement if not sponsorship." Handler Oral History, supra note 18, at 25.

142 See Raymond Moley, After Seven Years 304 (1939); Handler Oral History, supra note 18 , at 24-25. Wagner's importance in FDR's legislative program gave the Senator leverage not only to insist that his bill go forward, but also to fend off the Labor Department's efforts to weaken it. See id.

143 Harris, supra note 50, at I67. 
after the Supreme Court's nullification of the Recovery Act in May, I $935,{ }^{144}$ the New Deal was left without a program that either addressed economic recovery directly or eased the labor unrest that threatened recovery indirectly. Robert Wagner was ready in the wings with a portion of a recovery program, which bore the stamp of progressive debate and experience.

\section{Robert WagneR'S Progressivism: "IF WE INTEND to PURSUE THE PHILOSOPHY OF THE NEW ERA"}

Wagner wrote in March, I934, that obstructions to collective bargaining "cannot be allowed to continue if we intend to pursue the philosophy of the new era."145 Consistent with his location at the political confluence of various currents of progressive action, Wagner's surprisingly broad political "philosophy"146 blended three tendencies within reform thought - the technocratic corporatism and "growthmanship" associated with institutionalist economists such as Veblen and Tugwell, the responsibility-enhancing civic republicanism of

144 See A.L.A. Schechter Poultry Corp. v. U.S., 295 U.S. 495, 542 (1935). Although FDR had indicated his general support for the principles of the Wagner Act three days before the Schechter decision was announced, he first flatly stated his support for the Act itself after the Schechter ruling. See BRAND, supra note 49 , at 286 . Some opposition to the Wagner Act subsided because of expectations that it too would be declared unconstitutional. See Irons, supra note 78 , at $23 \mathrm{I}$.

145 Wagner, supra note 78 , at $\mathrm{I}$.

146 Wagner's political vision emerges - with unexpected breadth and coherence - from dozens of lengthy speeches, radio addresses and interviews, newspaper and journal articles, and private correspondence and discussion. As noted above at note 27 , Wagner's consistent public statements should carry weight under any appealing theory of statutory meaning, whatever his "true" motivations. In any event many close observers attest that he was an uncommonly principled legislator, that he did not deviate between his public and private arguments for his labor program, and that his words scrupulously reflected his beliefs and not those of aides, party leaders, colleagues, or the interests groups who sought his support. Simon Rifkind recalled:

No one, not even FDR or the other party leaders, could get him to say a single . . . word, unless he believed it. He went over the speeches word by word. He would not leave a word, a phrase, a sentence if he didn't believe it. You could not put a word in his mouth.

Rifkind Interview, supra note 98; see also Keyserling, supra note 104, at 215 ("I have never known so 'nonpolitical' a politician."); Handler Interview, supra note 91 (confirming Wagner's progressive convictions, personal control over legislative drafting, and respect among colleagues); Lubin Oral History, supra note 99, at 52 (confirming depth of Wagner's principled convictions). Historians agree. See, e.g., HUTHMACHER, supra note 55, at 108, III, I15; SCHLESINGER, supra note 50, at 224-35. Wagner's pronouncements about the Act are also particularly salient because its substance was in all important respects what Wagner wanted. See Casebeer, supra note $3 \mathrm{I}$, at 347 . 
Brandeis, and the social cooperationism of Dewey. ${ }^{147} \mathrm{He}$ attempted to link his broader, idiosyncratic vision with specific institutional models of labor-management cooperation associated with the practitioners of industrial relations within his reform network. The tensions and fault lines inscribed in the structure of the NLRA - particularly in the company union ban - reflect that attempt. ${ }^{148}$

\section{A. Pragmatist Premises: Scientific Guidance of the "Process of Becoming"}

Wagner situated both of his key labor legislative initiatives NIRA section 7 (a) and the NLRA - within the popularized pragmatist understanding of social experience and action to which most progressive intellectuals of the day adhered. 149 "We think of the ideal state," Wagner wrote in characteristically Deweyan rhetoric, "not as a fixed goal but as a process of becoming. ... And it is in the shifting scales of action and progress, and not by reference to a fixed star, however luminous, that the ideals of a modern state must be realistically judged." 150 According to the Deweyans, human con-

147 Of the broader categories of progressive political thinkers identified by James Kloppenberg, Wagner blended elements from ( $\mathrm{r}$ ) advocates of the bureaucratic, associative state, suitably reformed through scientific management and (2) those promoting a vision of the common good through "public welfare measures, labor legislation, and social responsibility," but not from (3) the antimonopolists or (4) the old Protestant elite that defended ethnic and cultural purity. KLOPPENBERG, supra note 95 , at 363 .

148 For Wagner, those tensions were eased by his pragmatist assumptions about an evolutionary path of mutual adjustment between legal norms and social facts. See infra sections IV.A.2 \& IV.B.2.

149 See, e.g., KLOPPENBERG, supra note 95, at 320; R. JEFFrey LuSTIG, Corporate LiBeralism: The Origins of MOdern AMERICAN Political TheORY, I8go-I920, at 156-75 (1982). Popularized pragmatism reflected a constellation of related ideas and slogans: a vision of a social world marked by constant flux and susceptible to deliberate political shaping; a belief that social communication could transform individual and social preferences and interests; and an urge to action based on present possibilities, scientific experiment, social consequences, and self-critical revision of goals, rather than on past precedents or fixed principles.

150 Robert Wagner, The Ideal Industrial State, N.Y. Trmes, May 9, I937 (Magazine), at 8 [hereinafter Wagner, Ideal Industrial State]. In an address at his alma mater, the City College of New York, on the role of the intellectual in public life, Wagner argued that unlike the "traditional" scholar, the pragmatic modernist, "steeped in the immediate present," had a vanguard role to play in public life. "To the modern, in the words of our own Professor [Morris R.] Cohen[,] the past is irretrievable and the future is unpredictable," Wagner said. "Only the present holds in its lap the wealth of sensation and the thrill of change which enjoy the undivided attention of the modern age." Robert F. Wagner, The Place of the Scholar in Public Life, Speech to Members of Phi Beta Kappa, C.C.N.Y. 4 (Nov. 24, I93I) [hereinafter Wagner, C.C.N.Y. Address] (transcript available in The Wagner Papers, supra note 30, at 599 SF ro2, Folder $2 x$ ). Wagner's words drip with popularized Deweyan and Jamesian pragmatism and its Emersonian antecedents. Dewey wrote,

Pragmatism, thus, presents itself as an extension of historical empiricism, but with this fundamental difference, that it does not insist upon antecedent phenomena but upon 
sciousness had a "creative constructive function"151 in the "process of becoming." Opportunities for intentionally guiding the trajectory of social change were everpresent. 152 Wagner, the legislative architect of the New Deal regulatory state, constantly propounded the practicability of intervention in a fluid social world. 153 He challenged particularly the residues of Scottish Realist and Spencerian claims about unchangeable economic "laws" that govern the labor market and labor relations inside the corporation. 154 Wagner's almost utopian optimism about social plasticity extended, significantly, to the malleability of the very consciousness that pragmatist thought identified as a dynamic element in social experience. ${ }^{155}$

Surveying the impact of the Recovery Act after one year, Wagner said, "Of far greater significance [than its economic effect] is our new faith in democratic government as an instrument for promoting the common weal."156 Dewey "defined the democratic polity as an exper-

consequent phenomena; not upon the precedents but upon the possibilities of action. And this change in point of view is almost revolutionary in its consequences. . . [ [T] his taking into consideration of the future takes us to the conception of a universe whose evolution is not finished, of a universe which is still, in James' term, "in the making," "in the process of becoming," of a universe up to a certain point still plastic.

John Dewey, The Development of American Pragmatism, in Philosophy and Crvilization I3, 24-25 (r93I). Wagner's appeal to present sensation and the thrill of change reflect the deep Emersonian influence on pragmatist thought. See generally CoRNEL WEST, The AMERICAN Evasion of Philosophy: A Genealogy of Pragmatism 9-4I, 69-iin (1989). For further instances of Wagner's appropriations of Dewey's ideas and very phrases, see infra pp. 141920.

151 DEWEY, supra note 150 , at 24 .

152 This view had penetrated to the center of the sociological jurisprudence and legal realism that began to influence Wagner when he was a judge in the I920s. See HUTHMACHER, supra note 55, at 45-49; Herbert Hovenkamp, Evolutionary Models in Jurisprndence, 64 TEx. L. REV. $645,67 x, 677-83$ (1985).

153 Wagner used virtually every plea for labor reform as an opportunity to challenge the "pretty fictions" of "Igth century economists and biologists." Robert F. Wagner, Address to the Associated Jewish Philanthropies I (Oct. 29, I933) (transcript available in The Wagner Papers, supra note 30 , at $600 \mathrm{SF}$ 103, Folder 28). "We shall yet find," he told an audience of social scientists, "that if there be such [economic] law it was written by our own ignorance and thoughtlessness, and that it can be erased by organization and control." Robert F. Wagner, Address to the Conference on Unemployment 5 (Dec. 30, I930) [hereinafter Wagner, Conference on Unemployment] (transcript available in The Wagner Papers, supra note 30 , at 546 SM 453).

154 Although Malthusian pessimism was less deeply rooted among American than British economists in the late nineteenth and early twentieth century, American economists nonetheless assumed that hard toil (rather than social redistribution) provided the only avenue to material progress for the working class in a world of scarcity. See, e.g., DANIEL T. RodGers, THE WORK ETHIC IN INDUSTRIAL AMERICA 1850-1920, at 99-102 (1978). According to Herbert Hovenkamp, vestiges of the nineteenth-century "wage-fund theory" - according to which income distribution was beyond governmental control - persisted into the r 930 s in jurisprudential thought. See Herbert Hovenkamp, The Political Economy of Substantive Due Process, 40 STAN. L. Rev. 379, 4I7-18, 437 (I988).

155 See infra pp. $1435-39$.

15678 CoNG. REC. 9336 (1934). 
imental polity capable of continually judging the results of its experimentation," 157 and in that definition Wagner concurred. The pragmatic, intersubjective search for truth by the scientific community was itself a model of self-government in the democratic community. ${ }^{158}$ Wagner described both the NIRA and the NLRA as evolutionary experiments in cooperative democracy - first efforts that would ultimately be small, though indispensable, components of the emerging administrative state. ${ }^{159}$

\section{B. Social Control and Planning in the Administrative State}

In a I930 keynote address to the leading progressive social scientists and economists in the country, Wagner declared that in the science "of human engineering you are the experts. It is your prerogative to prescribe for us the new economics of social control."160 The references to "human engineering" and "social control," although telling, are not necessarily as coldly technocratic as they might seem. By "social control," many progressives meant simply social self-regulation, which could be effected by either democratic or autocratic means and by either decentralized or centralized institutions. ${ }^{161}$ Although Wagner was committed to democratic determination of the ends of public

157 LuSTIG, sulpra note 149 , at I3I.

158 See, e.g., KLOPPENBERG, supra note 95, at 319-20; WALter LipPMANN, DRIFT AND MASTERy 274-75 (1914); David A. Hollinger, The Problem of Pragmatism in American History, 67 J. AM. HIST. 88, 99 ( 1980 ). Sharing the progressives' fascination with scientific method, Wagner frequently called for "[a] policy of deliberate experimentation." Robert F. Wagner, Address at the Convention of New York Brotherhood of Locomotive Firemen and Enginemen 24 (Sept. 15, 1932) (transcript available in The Wagner Papers, supra note 30, at 600 SF 103, Folder 25). He also urged social scientists to conduct research useful to legislators. See Wagner, Conference on Unemployment, supra note 153 , at 7-8.

${ }^{159}$ See, e.g., Robert F. Wagner, Industrial Recovery and Public Works Act, Address on NBC Radio I-7 (June 13, I933) [hereinafter Wagner, Industrial Recovery] (transcript available in The Wagner Papers, supra note 30 , at 600 SF ro3, Folder 28); Robert F. Wagner, Address on WOR Radio Broadcast 6-8, I2-I3 (May 18, I935) (transcript available in The Wagner Papers, supra note 30 , at 600 SF 103, Folder 34).

160 Wagner, Conference on Unemployment, supra note 153 , at 9.

161 See Robert B. Westbrook, John Dewey and American Democracy i88 (r99i). The words "social control" were "made . . . bywords in the Progressive era" by sociologist E.A. Ross's igor book, Social Control. Richard L. McCormick, The PARTY PERIOd ANd Public Policy 282-83 (I986). While many reformers understood "social control" as a catch-phrase broadly connoting opposition to laissez-faire as both a descriptive and prescriptive theory, see Morris Janowitz, The Last Half-Century: Societal Change and Politics in America 29 (1978), Wagner used the term more broadly still to encompass even laissez-faire, consistent with the legal realist understanding that even the common law of the "free market" was a form of social regulation. See Wagner, Ideal Industrial State, supra note 150, at 8. 
policy, ${ }^{162}$ he advocated centralized administrative agencies empowered to implement social planning on the basis of scientific expertise. ${ }^{163}$

Although the appeal of centralized administration and planning was intensified by the economic emergency, Wagner understood it to be a permanent requirement of the industrial state in the era of mass production. ${ }^{164}$ The intellectual groundwork for that view was laid during the Igros and I920s by such collectivist luminaries as Veblen, Herbert Croly, George Soule, and Stuart Chase, ${ }^{165}$ and by the less celebrated progressive engineers, managers, labor officials, and academics associated with the Taylor Society. They transformed scientific management from a theory of unilateral managerial control in the workplace into a vision of centralized administrative planning and decentralized collective bargaining in the larger political economy. Their views culminated in the overblown Veblenism of the Technocracy craze of I932, but also influenced the planning proposals of inner-circle New Dealers such as Tugwell, Moley, Berle, Lubin, and Wagner. ${ }^{166}$

In its substantive goals, Wagner's vision of economic planning had two proto-Keynesian components that advanced beyond the objectives of the earlier administrative-state-building phase of the Progressive Era: ${ }^{167}$ first, long-term national planning of public works spending to

162 See Robert F. Wagner, Speech at the National Conference of Catholic Charities 4 (Oct. 3 , 1933) (transcript available in The Wagner Papers, supra note 30 , at 600 SF 103, Folder 28).

163 "The new experimentalism in government imposes heavy but necessary duties upon administrative agencies," Wagner wrote after the establishment of the NRA in I933. "Few today will deny the pressing need for a greater degree of purposeful planning on a national scale." Robert F. Wagner, Planning in Place of Restraint, 22 SURv. Graphic 395, 396, 438 (I933).

164 See, e.g., Casebeer, supra note $3 \mathrm{I}$, at 317 .

165 Leading works of the technocratic planners include Stuart Chase, THe Nemesis of american Business and Other Essays (I931); Herbert Croly, Progressive Democracy (igi4); Herbert Croly, The Promise of American Life (igog); Thorstein Veblen, The Engineers and the Price System (1921); and George Soule, Hard Boiled Radicalism, New REPUBLIC, Jan. 2I, I93I, at 26r.

166 On the alliance of scientific management and labor progressives, see above pp. 1408-09, and below pp. 1429-30. Wagner's embrace of that alliance accounts for his fondness for the metaphor of social or human engineering. See, e.g., Wagner, Industrial Recovery, supra note 159, at I-2; S. J. Woolf, Wagner Foresees a New Industrial Day: Out of His Experience as a Labor Mediator the Senator Finds Encouragement for a Better Economic Order, N.Y. TimEs, Nov. 12, 1933, $\$ 6$ (Magazine), at 6 . On the collectivist planners, see WilliaM E. AkIN,

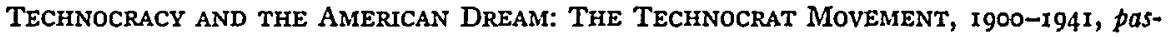
sim (1977); SCHLESINGER, supra note I4I, at 193-95; R. G. TUGWELl, The Brains TRUST 99-100 (rg68). Although scientific management reinforced many progressives' attraction to expert, centralized administration as a means of suppressing or evading political conflict, even progressives of a more democratic bent, like Frankfurter, Hillman, and Wagner, embraced both scientific management and economic planning. See, e.g., Frankfurter, supra note i17, 135-36. ${ }^{167}$ See generally Martin SkLaR, The CoRporate Reconstruction of AMERICAN Capi- 
achieve countercyclical stabilization; second, enhancement of mass purchasing power through redistribution of bargaining power from capital to labor. ${ }^{168}$ The desirable effect of high wages on consumption and work motivation was a tenet not only of New Deal economic thought, but of the popular "new economics" of the I920s. ${ }^{169}$ Almost alone within the inner circle of the New Deal, however, Wagner linked that tenet to aggressive support for collective bargaining as the means to permanent economic redistribution and growth. ${ }^{170}$

In its administrative form, Wagner's vision of economic planning evolved during the I930s from comprehensive, centralized administrative control, which he was willing to label "state socialism,"171 to administrative enforcement of corporatist planning by peak organizations of private groups, ${ }^{172}$ to administrative oversight of more decentralized collective bargaining. ${ }^{173}$ Wagner capsulized his consis-

TALISM, I890-1916, at $177-212,248-85$ (1988) (emphasizing that state-building in the progressive era aimed to construct corporate forms and competitive markets).

168 Virtually from the time Wagner entered the Senate in 1927 , he was the leading Congressional voice for a labor market program to expand mass consumption. See HUTHMACHER, supra note 55, at 57-69 (detailing Wagner's first efforts to combat unemployment and expand purchasing power); Robert F. Wagner, Sound Policy to Break Bread Lines, THE INDEPENDENT, Apr. $\mathrm{r}_{4}, \mathrm{I928}$, at 353,353-54. Both the Senate report and Wagner's lengthy introduction to his labor relations bill on the Senate floor emphasize the goal of increasing mass purchasing power, both as a matter of distributive justice, see 79 CoNG. REC. 7565,7567 (1935) (statement of Sen. Wagner), reprinted in 2 LEGISLATIVE HISTORY, supra note 38 , at 2326 , and as the crucial foundation for macroeconomic stabilization, see id. at 7568,7572 , reprinted in 2 LEGISLATIVE HistoRy, supra note 38 , at 2330, 2339-40; S. REP. No. 573, 74th Cong., Ist Sess. I8 (1935), reprinted in 2 LEGISLATIVE HISTORX, supra note 38 , at 23I8; see also NLRA, supra note $3, \S \mathrm{I}, 29$ U.S.C. $\S$ I5I (I988) ("The inequality of bargaining power [between employees and employers] tends to aggravate recurrent business depressions, by depressing wage rates and the purchasing power of wage earners.").

169 See William J. Barber, From New Era to New Deal: Herbert Hoover, the ECONOMISTS, AND AMERICAN ECONOMIC POLICY, I92I-I933, at 28, 84 (I985); Thoedore Rosenof, Dogma, Depression, and the New Deal 39 (1975). Proponents of the high-wage theory, such as Wagner, paid scant attention to the crucial question of how nominal wage hikes would affect pricing and investment decisions, real output, and ultimately real purchasing power. Compare PIORE \& SABLE, supra note IO, at 79-82 (arguing that collective bargaining maintained the mass market in post-World War II) with Martin L. Weitzman, Profit-Sharing Capitalism, in Alternatives to Capitalism 6I, 62 (Jon Elster \& Karl O. Moene eds., I989) (arguing that resulting downward wage rigidity may have actually aggravated economic fluctuations).

170 See SChlesinger, supra note 50, at 403 ("Wagner was almost alone among liberal democrats in placing a high value on trade unions."). In his introduction of the NLRA to the Senate, Wagner posed a stark three-way choice between maintenance of purchasing power through collective bargaining, "sustain[ing] the market indefinitely by huge and continuous public spending," or "the certainty of another collapse." 76 CoNG. Rec. 7565,7568 (I935) (statement of Sen. Wagner), reprinted in 2 LEGISLATIVE HISTORY, supra note 38 , at 2330.

171 Robert Wagner, Danger Ahead!, LIBERTy, July 23, r932, at 6, 9.

172 See infra pp. ${ }^{4} 420-2 \mathrm{I}$.

${ }^{173}$ See Robert Wagner, "Industrial Democracy" and Cooperations, Radio Address at the National Democratic Club 4 (May 8, 1937) (transcript available in The Wagner Papers, supra note 30 , at $600 \mathrm{SF}$ 103, Folder 38 ) (rejecting "super-government" in which unions are "creatures 
tently pragmatist conception of economic planning in his I934 defense of Tugwell against accusations of communism:

[B]y planning [Tugwell] means merely the scientific approach to problems of social control. . . .

.. . It is a constant process of trial and error, with social interests paramount, social control present, and any particular panacea subordinate to results. . . . Is this shocking? . . . Is it not in accord with the idea [embodied in the NRA] of continuing cooperation and readjustment among industry, labor, and government? ${ }^{174}$

Wagner gave concrete institutional content to his rhetoric of "cooperation," with specific implications for labor law, in the debates surrounding the drafting of the NIRA and the NLRA.

\section{C. "Building . . . a Co-operative Order" in the Age of Fordism}

Of "the major forces which are at large upon the present day scene," one Wagner thought most fundamental was the rise of industrial mass production. ${ }^{175}$ The twin policy problems posed by largescale industry, in his view, were the depersonalization and diminishing bargaining power of the individual worker, ${ }^{176}$ on the one hand, and the heightened importance - tragically demonstrated by the Depression - of maintaining mass purchasing power for macroeconomic stabilization and growth, on the other. ${ }^{177}$ By the time he led the drafting of the Recovery Act, Wagner had come to believe that the

of the state" and trade associations are "cartels of the state"). Nonetheless, Wagner never abandoned his vision of some form of corporatist planning that transcended or supplemented decentralized collective bargaining. See infra p. 1425 .

${ }^{174}$ Robert F. Wagner, Speech on the Confirmation of Dr. Tugwell I0-11 (June, 1934) [undelivered], (available in The Wagner Papers, supra note 30 , at $600 \mathrm{SF}$ 103, Folder 30).

175 Wagner, C.C.N.Y. Address, supra note 150 , at 4, 7-12; see also 79 CoNG. REc. 7565, 7567 (1935) (statement of Sen. Wagner), reprinted in 2 LEgISLATIVE HISTORY, supra note 38 , at 2325-26 (introducing NLRA).

176 See 79 CoNG. REC. 7565 , reprinted in 2 LEgisLative HistoRy, supra note 38 , at 2321 (arguing that the worker is "[c]aught in the labyrinth of modern industrialism and dwarfed by the size of corporate enterprise"); Wagner, Address on WOR Radio Broadcast, supra note 159, at 3 ("The vast size of corporate enterprise ... [ [has] made the individual a helpless plaything of forces beyond his control.").

177 See 79 CONG. REC. 7565,7567 (1935) (statement of Sen. Wagner), reprinted in 2 LEGISLATIVE HISTORY, supra note 38 , at 2325-26 (arguing that industrial concentration correlated with maldistribution and the failure of mass purchasing power, which "was particularly serious in an age of mass production"); Robert F. Wagner, Speech at Syracuse, N.Y. 12 (Oct. 21, 1932) (transcript available in The Wagner Papers, supra note 30, at 600 SF 103, Folder 26) ("Unless there is purchasing power in the hands of the great masses of people there will be no purchasers for the products of American mass production."). 
progressivist idea ${ }^{178}$ of "building . . . a co-operative order" was the lodestar for the social reconstruction necessary in the era of mass production. ${ }^{179}$

Wagner's ideal of social cooperation should not be conflated with the early Roosevelt Administration's ephemeral deployment of the language of "cooperationism."180 His deeper commitment can be traced to three cross-pollinated strains of progressive thought that expressed the cooperative idea at different levels of philosophical and institutional specificity: the communitarian progressivists, the institutionalist economists, and progressive industrial relations practitioners and experts. ${ }^{181}$

Wagner appropriated Dewey's popularized communitarian terminology when he argued that industrialism had generated an atomized, yet interdependent "Great Society"182 that "grop[ed] desperately for salvation through cooperation"183 and demanded a regeneration of the social bonds of a "Great Community." For Wagner, as for Dewey, the cooperative ethos - an ideal of "reciprocal solidarity"184 — was to inform both daily interaction in the workplace and other local settings, and large-scale democratic politics. The Deweyan vision of the democratic polity drew on an overarching conception of egalitarian communication and its byproduct, the socially endogenous and selfreflexive transformation of social interests. ${ }^{185}$ Keyserling recalled that

178 On the centrality in progressive thought of the cooperativist ethos and the attendant need for moral transformation, see, for example, BRAND, cited above in note 49, at 78-79; JoHN DEWEY, INDIVIDUALISM OLD AND NEW 6I, 85-86 (I929); KLOPPENBERG, cited above in note 95, at 334-36,348,40r-03; and LuSTIG, cited above in note I49, at II2.

179 Wagner, supra note 30, at 6; see also 79 CoNG. Rec. 6r83-84 (1953) (address by Sen. Wagner), reprinted in 2 LEgISLATIVE HISTORY, supra note 38, at 2283; Robert F. Wagner, Address on WJZ Radio on the National Labor Board I0-II (Sept. I8, 1933) (transcript available in The Wagner Papers, supra note 30 , at 600 SF I03, Folder 28) (expressing same idea).

180 Wagner's commitment to a politics and economics of cooperation predated the NRA period and persisted into the NLRA years, and was linked throughout to the particular role of labor in society - unlike the vaguer, rhetorical "cooperationism" of many early New Dealers. See Alan Brinkley, The New Deal and the Idea of the State, in ThE RISE AND Fall of THE NEw DEAL ORDER, I930-I980, supra note 44, at 85, 93, I00; James Holt, The New Deal and the American Anti-Statist Tradition, in The NEw Deal: The National Levei. 27, 33-35 (John Braeman, Robert H. Bremner \& David Brody eds., 1975).

181 All three strains were well represented among Wagner's closest advisers and associates. See supra section II.E; infra section III.E.

182 Wagner, supra note 162 , at 4 . For Dewey's formulation of the "Great Society" and "Great Community," see John Dewey, The Public and Its Problems 96-98, I26-28, I55-57 (2d. ed. I946) (I927).

18379 CONG. REC. 14,229 (1935) (statement of Sen. Wagner).

184 DEwEy, supra note $x 78$, at $6 \mathrm{I}, 85-86$.

185 The "Great Community" would perfect "the means and ways of communication of meanings so that genuinely shared interest in the consequences of interdependent activities may inform desire and effort and thereby direct action." DEWEY, supra note I82, at 155 . That conception accounts in part for the parallel that Dewey, Wagner, and other progressives often 
the Senator not only "envisaged the collective bargaining process as a cooperative venture guided by intelligence, rather than a mere test of relative strength," but also "foresaw that this process within our enterprise system could become an integral part of an ever larger cooperative process guided by intelligence" in the economy and polity at large. 186

Wagner situated his specific legislative innovations within this more abstract cooperationist vision. He understood his recovery program to be constituted by three specific mechanisms of social cooperation, each of which was to be supervised and enforced in the public interest by the new administrative state. ${ }^{187}$ The first was cooperation among businesses, through governmentally supervised codes of competition generated principally by trade associations. ${ }^{188}$ This aspect of Wagner's program embraced the institutionalists' commitment to industrial "cooperation" and "control" rather than competition. $189 \mathrm{He}$ nonetheless took pains to associate his stance as well with Brandeis, the apostle of antitrust. Wagner accurately reminded the Senate that

drew between democratic and scientific communities: both were thought ideally to embody the application of "critical intelligence" in the egalitarian intersubjective search for pragmatic truths. See, e.g., Hilary Putnam, A Reconsideration of Deweyan Democracy, 63 S. CAL. L. ReV. 167I, r682-83, 1685-88 (1990).

186 Keyserling, supra note 104, at $22 \mathrm{r}$.

187 See Robert F. Wagner, NBC Radio Symposium on the National Labor Board 3 (Oct. 3I, 1933) (transcript available in The Wagner Papers, supra note 30 , at 600 SF 103, Folder 28).

188 In this, Wagner was not simply following the drift of the Roosevelt administration. Even before the I932 election, Wagner had Rifkind and Handler study the possibilities for antitrust revision along these lines, and, in April, 1933, the White House followed Wagner's lead in undertaking the formulation of comprehensive recovery program proposals. See Himmelberg, supra note 136 , at 200-01. This aspect of the recovery program - the relaxation of antitrust regulation and the endorsement of industrial self-government via trade associations - reflected the influence of business planners, transmitted principally through Assistant Secretary of Commerce John Dickinson. See id. at 20I-04. Although legislative endorsement of this form of business cooperation marked the culmination of the trade association movement of the 1920s, it was also embraced by corporatist progressives such as Wagner, Tugwell, Lubin, Hillman, and Richberg. The latter accepted the inevitability of industrial concentration and welcomed the economies of scale of mass production but wished to add government supervision and the countervailing power of labor to business self-regulation of "waste[ful]" competition. 77 CoNG. REC. $515^{2}$ (r933) (statement of Sen. Wagner); see also ERIC F. Goldman, Rendezvous with DESTINY 259-65 (abr. ed. 1955) (recounting Moley's defense of mass production and industrial concentration).

189 Rexford G. Tugwell, The Industrial Discipline and the Governmental Arts I3-20, I I2 (1933). On this count, Wagner's ideology was heir to the New Nationalism program of Van Hise and Croly, incorporated in the Veblenian institutionalist economics of Wagner's key economic advisers, Lubin and Keyserling. See, e.g., Croly, The Promise of AMERICAN Life, supra note 165, at 358-59; Charles R. VAN Hise, ConCENTRATION AND CONTROL 277-78 (rev. ed. 1914). For a description of their influence, first on the New Nationalism of Theodore Roosevelt and then on the economic policy of the New Deal, see Ellis W. Hawley, THE New Deal and the Problem of Monopoly 43-46 (ig66); David W. Levy, Herbert Croly OF THE NEW REPUBLIC passim (1985); and SCHLESINGER, supra note 5o, at 179-80. 
Brandeis endorsed business "cooperation" when it could be said to "purif[y]" or "promote" competition. ${ }^{190}$ The "purification" that Wagner had chiefly in mind in his sponsorship of the NRA code scheme was the industry-by-industry standardization of minimum labor conditions to ensure that competition did not take the form of "destructive" wage cutting and sweating of labor. ${ }^{191}$ But, consistent with his and other leading progressives' more sweeping cooperationist vision, Wagner believed that the end of labor sweating was but an instance of a visionary, culture-shaping project initiated by the Recovery program. 192

The second institutional mechanism, also necessitated by the rise of large-scale enterprise, was cooperation among workers via unionization. This would provide the organizational predicate for the functional representation of labor alongside the organizations of capital in both collective bargaining and governmentally supervised corporatist planning. Collective bargaining and corporatist planning, then, would embody the third and, for Wagner, the "most important" form of cooperation, that between labor and business. 193

Wagner understood the implementation of the three mechanisms of governmentally supervised cooperation - among businesses, among workers, between business and labor - as more than merely encouraging and relabelling the familiar institutions of, respectively, trade associations, unions, and collective bargaining. ${ }^{194}$ Rather, each re-

190 See 77 CoNG. REc. 5 I53 (I933) (quoting American Column \& Lumber Co. v. United States, 257 U.S. 377, 418 (I92 I) (Brandeis, J., dissenting)); see also FRASER, supra note 47, at 270-72 (arguing that Brandeis did not naively oppose business concentration and coordination where economically justified, but rather opposed the interwar "securities bloc"); Thomas $\mathrm{K}$. McCraw, Rethinking the Trust Question, in Regulation IN Perspectrve I, 29 (Thomas $\mathrm{K}$. McCraw ed., I98I) (noting that Brandeis approved cooperation among smaller producers).

191 See Robert F. Wagner, Speech over NBC Radio 2-4 (May 19, I933) (transcript available in The Wagner Papers, supra note 30 , at 600 SF 103, Folder 27); Robert F. Wagner, Address on the NIR Bill 3-4 (May 22, I933) (transcript available in The Wagner Papers, supra note 30, at $600 \mathrm{SF}$ 103, Folder 27); Robert F. Wagner, Address on NBC Radio on the NIR Bill I-3 (May 26, I933) (transcript available in The Wagner Papers, supra note 30 , at 600 SF I03, Folder 27). For contemporary arguments about cooperative paths to high-skill, high-wage economic development as alternatives to low-wage, labor-sweating strategies, see PIORE \& SABEL, supra note 10, at 270-72; Hyman, supra note 14 , at 53 .

Business interests, of course, understood the purposes of the code-formulating provisions of the vaguely drafted NIRA differently than did Wagner. While he stressed the possibilities for improvement and stabilization of labor conditions, they hoped to use the code authority for cartel-like price setting and capacity restriction. See HAWLEY, supra note 189, at 35-39; HIMMELBERG, supra note 136, at 208-12.

192 See supra pp. I422, I435-38.

193 Wagner, Radio Symposium, supra note 187 , at 3. "[O]ne [cannot] imagine a single huge employer cooperating separately with each of 10,000 or 50,000 workers. Cooperation depends upon the untrammeled right of workers to organize for that purpose." 79 CoNG. REc. 6183, 6 I84 (I935), reprinted in 2 LEGISLATIVE HISTORY, supra note 38 , at 2283.

194 Wagner said that the kind of cooperation between labor and industry he envisioned was "something entirely new in our history." Wagner, supra note 187 , at 3. 
quired a new cooperative mentality, transforming the subjective interests and perceptions of labor and management. He envisioned, in short, a culture of cooperation fit for a political economy of democratic corporatism - a regeneration of "moral responsibility" even in commercial relations. ${ }^{195}$ Before examining in more detail the theory and practice of Wagner's brand of labor-capital cooperation, it is necessary to sketch Wagner's view of worker empowerment, democratic consent, and actual liberty of contract. For he believed that workers' genuine consent provided the necessary legal and social foundation for both workplace and political cooperationism.

\section{Sovereign Power and Substantive Freedom in the Large-Scale Enterprise and the Polity}

For Wagner, the large-scale, hierarchical workplace of mass production was "an impersonalized and heartless machine" in which "the isolated worker . . . is powerless to defend himself against the occasional wrong of the corporation which controls him ... . [and] is expressionless to convey to the management what his problems are."196 The relation between employer and employee in modern industry "the most important relationship" in the worker's life ${ }^{197}$ - had taken on the character of the authority relationship between sovereign and subject or citizen. In his introduction of the NLRA in the Senate, Wagner quoted Brandeis's charge that employers who sought legal sanction for their obstruction of worker organization were "seeking sovereign power" - seeking "to endow property with active, militant power which would make it dominant over men."198 The analogy between political and managerial power had lodged firmly in the progressive mind at the height of political appeals for industrial democracy during and after the First World War. ${ }^{199}$ Many corporate leaders, too, had come to justify their exercise of political influence

195 Woolf, supra note 166 , at 6 . In this respect, he was aligned particularly with Adolph Berle, the leading voice in FDR's Brains Trust to call for a new moral credo for business. See SCHLESINGER, supra note 50, at 183 . For perceptive analyses of the utopian strain in NRA policy, see BRAND, supra note 49, at 81, 94-95; and Harris, supra note 50, at 169 , and in progressivism generally, see sources cited above in note 178 .

196 8I CoNG. REC. 2940 (1937).

197 Wagner, supra note 162 , at 3 .

19879 CoNG. REC. 7565, 7566 (I935) (statement of Sen. Wagner), reprinted in 2 LEGISLATIVE HISTORY, supra note 38, at 2325 (quoting Truax v. Corrigan, 257 U.S. 312, 368 (192 I) (Brandeis, J., dissenting)).

199 See generally Mrlton Derber, The American Idea of Industrial Democracy in I95 (describing the development of the idea of industrial democracy); RoDGERS, supra note 154, at 57-6r (same); Clyde W. Summers, Industrial Democracy: America's Unfulfilled Promise, 28 Clev. St. L. REV. 29, 29-34 (I979) (same). 
by the sovereign-like authority they already wielded as "industrial statesmen" controlling the "vital institutions" of social life. ${ }^{200}$

In light of his embrace of the analogy between political and industrial power, it is not surprising that Wagner, an ardent liberal democrat, thought the most fundamental purpose of the statutory right to collective bargaining was to afford workers sufficient substantive freedom to enable them genuinely to consent to workplace authority relations. While the diminished bargaining power of individual workers vitiated the normative force of their voluntary choice to submit to the authority of the large-scale enterprise, collective bargaining would empower workers sufficiently to cleanse that choice of duress. ${ }^{201}$ Workers would cross the normative line - between false and genuine democratic consent to authority, between duress and actual liberty of contract, between unjust inequality and just equality of bargaining power - when empowered to bargain collectively rather than individually. Collective bargaining would thus legitimate the management-labor authority relationship in the age of mass production.

For Wagner, even the important legislative goals of industrial peace and macro-economic growth and stabilization were always secondary to the achievement of social justice through democratic consent in the workplace. ${ }^{202}$ As to industrial peace, Wagner often advanced the proposition that tranquil labor relationships were not the sole consideration: "It all depends upon the basis of tranquility. The slave system of the old South was as tranquil as a summer's day, but that is no reason for perpetuating in modern industry any of the aspects of a master-servant relationship."203 And, although Wagner was one of the earliest advocates of counter-cyclical public spending and redistribution to sustain mass purchasing power, he often said unequivocally that "the moral injustice of gross inequality . . . is more important than its economic unsoundness. ... Economic stabilization is desirable; social justice is imperative."204 Wagner further insisted,

200 LUSTIG, supra note 149 , at II4-I5.

201 See 78 CONG. REc. 3678,3679 (I934) (statement of Sen. Wagner), reprinted in I LEGISLATIVE HISTORY, supra note 38 , at 20 (equating actual liberty of contract with freedom from duress due to unequal bargaining power); S. 2926, 73d. Cong., 2d Sess. § 2 (1934), reprinted in I LEGISLATIVE FISTORY, supra note 38 , at I (identifying centralized and integrated economic activity as cause of inequality of bargaining power that negates actual liberty of contract); NLRA, supra note $3, \S \mathrm{I}, 29$ U.S.C. $\S$ I5I (I988) (stating that employees lack equality of bargaining power and actual liberty of contract).

202 See supra note $3 \mathrm{I}$.

${ }^{203}$ Robert F. Wagner, Company Unions: A Vast Industrial Issue, N.Y. TrMES, Mar. II, 1934, § 9, at I. "Yet peace is not all. There are values we hold above peace. . . A And first among these is liberty. It is because of the guarantees of liberty that the Labor Relations decisions are so important." Wagner, supra note 173 , at 7 ; see also 78 CONG. REC. I2,04I, 12,044 (1934) (statement of Sen. Wagner), reprinted in I LEGISLATIVE HISTORY, supra note 38, at 124 I (expressing same idea).

204 Wagner, supra note 162 , at 2; see also Wagner, supra note 163 , at 438 (arguing that 
in an exchange of letters with John Dewey, that even if distributive justice could be achieved by tax-and-transfer policies, the latter would not remedy the injustice of authoritarianism within workplace relations. ${ }^{205}$ Only collective empowerment would implement "the new freedom" - "a freedom for self-direction, self-control, cooperation."206

That the idea of substantive or positive freedom was at the heart of Wagner's philosophy is not surprising in light of the centrality of that idea in American progressivism. ${ }^{207}$ In applying that idea to labor relations, Wagner consistently deployed the moral vocabulary of two currents of progressivism represented among his closest advisers and associates: the institutionalists' discourse of the workplace as a constitutional democracy, ${ }^{208}$ and the legal realists' language of economic duress and substantive liberty of contract in the labor market. ${ }^{209}$

government must "relegate even the difficult problem of eliminating the business cycle to a position subordinate to the establishment of actual justice for the man who toils"); 79 CoNG. REC. 7565,7567 (I935), reprinted in I LEGISLATIVE HISTORY, supra note 38, at 2326 (condemning maldistribution of income judged by a standard of minimal need).

205 See Letter from Robert Wagner to John Dewey 2 (Feb. 14, I934) (on file in The Wagner

Papers, supra note 30 , at 562 GF 325 , Folder 26).

206 Wagner, supra note 173 , at 7 .

207 See KLOPPENBERG, supra note 95, at 401-03.

208 Typical of Wagner's use of institutionalist discourse was the following:

[T]here can no more be democratic self-government in industry without workers participating therein, than there could be democratic government in politics without workers having the right to vote. . . . That is why the right to bargain collectively is at the bottom of social justice for the worker . . . . The denial or observance of this right means the difference between despotism and democracy.

Wagner, Democratic Club, supra note I 73 , at 4-5. The institutionalists believed that the analogy to democracy in politics not only underpinned their core normative proposition that workplace authority should rest on the consent of the workers, see William Leiserson, Contributions of Personnel Management to Improved Labor Relations, in 1928 WERTHEIM LeCTURES ON INDUSTRIAL RELATIONS 125, I60 (I929), but also provided a positive explanation for workers' demands for collective bargaining. "The idea that government derives its powers from the consent of the governed," wrote Leiserson in 1926 , "'is too fundamentally ingrained in the mind of every American for wage-earners to be contented with absolute government in industry where they spend the greater part of their lives." EISNER, supra note 107, at 40 (quoting an unpublished manuscript by Leiserson). This argument, too, was repeatedly echoed by Wagner. See, e.g., Robert F. Wagner, Speech before the New York Labor Institute 5-6 (Feb. 29, 1936) [hereinafter Wagner, Labor Institute] (transcript available in The Wagner Papers, supra note 30, at 600 SF 103, Folder 36); Robert F. Wagner, Talk on Labor Relations 9-10 (Feb. 29, 1936) (transcript available in The Wagner Papers, supra note 30, at 600 SF 103, Folder 36).

209 Like the realists, Wagner understood the employment relationship as the paradigm for equating the powers of property and sovereignty and blurring the line between public and private action. See, e.g., Morris R. Cohen, Property and Sovereignty, 13 CoRnell L.Q. 8, 814 (1927); Robert L. Hale, Labor Legislation as an Enlargement of Individual Liberty, I5 AM. LAB. LEGIS. REV. 155, 155-60 (1925); Wagner, Address on the NIR Bill, supra note 191, at 4 (stating that the bill reflects the "new blend of public and private action"). In the debates of the r 930 s on labor policy, Wagner routinely voiced the characteristically realist arguments about coercion and substantive freedom in the labor market. The realist Robert Hale testified that workers' market freedom to enter and exit employment did not legitimate yellow-dog contracts: 
For Wagner, collective empowerment in the labor market was necessary not only to achieve genuine consent in the workplace, but also to secure democratic consent in the new cooperative political order at large. First, when he put forward his labor bills in I934 and I935, Wagner stressed the importance for democratic corporatism of achieving the countervailing organized power of labor against capital. ${ }^{210} \mathrm{He}$ also insisted both that those bills protected basic worker rights that normatively pre-existed the NIRA's relaxation of antitrust strictures, and that the democratic function of the "correlative organization of labor" in "checking" the power of large-scale enterprise would outlast the NIRA's specific scheme of corporatist planning. ${ }^{211}$

[I]n a complicated modern society like ours, nobody is going to be entirely free. . . [A]n employee of a [nonunion] steel company ... has no freedom as to the details of his work whatever; he is a non-voting member of a society. Now, if he belongs to a union in a closed-shop industry, it is perfectly true he has no freedom to work without being a member of the union, but he has a little more freedcm through the brotherhood of his union against the restraint imposed upon him by the employer. . . . If he is subject to be governed by the rules of his union he presumably has a little more control over what those rules are than if he is governed solely by the rules laid down by his employer. So I think the moment you reflect a little bit on that notion of individual freedom, you see that it breaks down.

Hearings on S. 2926, supra note 65, at 5 I (statement of Robert L. Hale, Professor of Law, Columbia University), reprinted in I Legislative HistoRY, supra note 38, at 81. Drawing on the repertoire of realist arguments against Lochner v. New York and its progeny, see, e.g., Lochner v. New York, x98 U.S. 45 (1905); Coppage v. Kansas, 236 U.S. I (I915), Wagner said that the individual worker's exit option provided a merely "mythical freedom of action," 75 CoNG. REc. 49 I5 (1932), because holding out against an employer's terms meant "fac[ing] ruin for [the employee's] family." Hearings on $S$. 2926, supra note 65 , at 17 , reprinted in I LEGISLATIVE HISTORY, supra note 38 , at 47 . The view that the employer-employee relationship was marked by coercion and power disparity was held not only by the realists, but also by the institutionalist labor economists. See, e.g., Neil W. Chamberlain, The Institutional Economics of John $R$. Commons, in Joseph Dorfman, C. E. Ayres, Neil W. Chamberlain, Simon KuzNETS \& R. A. GoRdon, Institutional ECONOMics 63, 9i (I963).

210 Although the NRA "experiment" disillusioned Wagner about the ease of achieving "constructiven cooperation among enterprises, it only intensified his belief that cooperation between labor and capital through "industrial democracy" was the linchpin of democratic renewal in the wider polity. As corporate trade associations quickly came to dominate the NRA code-writing process and simultaneously blocked collective bargaining by interposing company unions, Wagner repeatedly raised the alarm that only half of the corporatist Recovery Act was being implemented. "This process of economic self-rule under the code system must fail unless every group is equally well represented." 78 CONG. REC. I2,0I7 (1934), reprinted in I LEGISLATIVE HistoRy, supra note 38, at Ir8I; see also Letter from Robert F. Wagner to Congressman George W. Johnson I (Apr. 2, I934) (on file in The Wagner Papers, supra note 30, at 694 LA 7 r5, Folder 8) (expressing same idea).

211 See 78 CONG. REC. 12,016, 12,017 (1934), reprinted in I LEGISLATIVE HISTORY, supra note 38, at I 18I ("The Recovery Act did not give employees any rights of organization to which they were not entitled before the act was passed."); Wagner, Ideal Industrial State, supra note 150, at 9. Even after the NRA slipped into irretrievable crisis, Wagner still envisioned a polity that would be based on cooperation and administrative planning, if in some unspecified form other than NRA-style corporatism. The countervailing organized power of labor would, in such 
Second, and equally important, organized labor would act as an antidote to the dangers of autocracy posed by the newly fortified administrative state. ${ }^{212}$ Like other leading progressive proponents of expert administration, ${ }^{213}$ Wagner was far from oblivious to the threat posed by technocratic bureaucracy to the individual voluntarism necessary for genuine reciprocal solidarity. ${ }^{214}$ Because democratic citizens' daily experience of "responsibility" is necessary to their "intellectual, moral and spiritual development," Louis Brandeis wrote in I922, "no remedy can be hopeful which does not devolve upon the workers' participation in, responsibility for the conduct of business . . . ."215 Ten years later, Wagner repeatedly used the Brandeisian language of civic republicanism in his defense of legal protection for workers' collective action. To replenish the fading civic virtues of "the old New England town meeting" in an increasingly "impersonalized" administrative state, ${ }^{216}$ and to nurture "the dignity of freedom and selfexpression in [workers'] daily lives," Wagner prescribed the "road of organized action to responsibility [and] self-mastery."217

Wagner believed there was no turning back from mass production or from the empowered technocratic state. Indeed, he anticipated that the functions of the administrative state would be vastly multiplied. Yet he also believed that industrial democracy would afford decentralized, countervailing power and a renewed culture of democracyfrom-below. In this way, Wagner amalgamated corporatist technocracy with both civic republicanism and the communitarian commitment to creating new seedbeds of solidaristic culture. ${ }^{218}$ As discussed

a polity, still be indispensable to a democratic equilibrium of social forces. See Casebeer, supra note 31 , at 316 .

212 "[L]et men know the dignity of freedom and self-expression in their daily lives, and they will never bow to tyranny in any quarter of their national life." Wagner, Ideal Industrial State, supra note 150 , at 23 .

213 See KLOPPENBERG, supra note 95, at $\mathrm{r} \mathrm{I}, 353,358-6 \mathrm{I}, 38 \mathrm{I}-94$.

214 The New Deal demonstrated that "the complexities of modern life demand an increasing concentration of the [state] power to formulate and unify decisions." But such centralization posed the possibility of an "autocrat[ic] misuse [of] power." Wagner, Ideal Industrial State, supra note 150 , at 23 .

215 STRUM, supra note I 8 , at 192 (quoting letter from Brandeis to Henry Bruère). Brandeis believed that the ultimate aim of industrial democracy should be workers' assumption of "full responsibility" for business, "as in cooperative enterprises." Id; see also Louis D. BRANDEIS, How Far Have We Come on the Road to Industrial Democracy? - An Interview, in THE Curse of Bigness: Miscellaneous Papers of Louis D. Brandeis 35, 43, 47 (Osmond $\mathrm{K}$. Fraenkel ed., 1934) (stating that the penultimate stage in the industrial struggle will be "the sharing of responsibility, as well as profits," and that "[t]he eventual outcome promises to be full grown industrial democracy").

216 Wagner, Ideal Industrial State, supra note 150 , at 23.

21775 CONG. REC. 4918 (1932); see also 78 CONG. REC. 4229,4230 (1934), reprinted in 1 LEGislative HISTORY, supra note 38 , at 22,24 (stating that participatory decisionmaking in industry is necessary to compensate for impersonalized government).

${ }^{218}$ For further discussion of the progressives' embrace of the Tocquevillian idea of inter- 
in the next section, Wagner thought that the collective empowerment necessary for democratic consent in the enterprise and polity was also essential for collaboration in workplace production.

\section{E. Labor-Management Cooperation in Progressive Labor Thought and Practice}

For Wagner, workplace cooperation required that labor feel trust toward management, take responsibility for productive efficiency, and recognize shared, rather than adversarial, interests in the common enterprise. But, Wagner was convinced, that mentality could rest only on labor's sense that it would share fairly in the economic fruits of such productivity-enhancing attitudes; and that sense, in turn, depended on the security and consent of the workforce which only collective empowerment could supply. ${ }^{219}$

Wagner's normative understanding of collective bargaining, then, was profoundly integrationist and cooperationist, not conflictual and adversarial as is conventionally supposed. ${ }^{220}$ His vision of labor relations was embedded in his progressivist assumption that the proper deployment of social science and administrative technique, and redis-

mediate groups as schools for democracy, see, for example, WESTBRooK, cited above in note 16I, at xvi, 434; and David E. Price, Community and Control: Critical Democratic Theory in the Progressive Period, 68 AM. Pol. ScI. Rev. I663, 1666-67 (1974). On the tension between the technocratic and democratic poles within progressivism, see, for example, Richard W. Fox, Epitaph for Middletown: Robert S. Lynd and the Analysis of Consumer Culture, in THE CULTURE OF CONSUMPTION I03, I28-29, I60 (Richard W. Fox \& T.J. Jackson Lears eds., 1983).

219 See 78 CONG. REC. 3678,3679 (1934), reprinted in I LEGISLATIVE HISTORY, supra note 38 , at 20 ("The primary requirement for cooperation is that employers and employees should possess equality of bargaining power."); see also 79 CoNG. Rec. 6183, 6184 (1935), reprinted in 2 Legislative HistoRX, supra note 38 , at 2283 (expressing same idea); 75 CoNG. REC. 4918 (1932) (expressing same idea). The theoretical implications of Wagner's thinking on this issue are explored at length below in section IV.C. Wagner's view accorded with other post-war labor progressives attuned to scientific management who thought independent unions, by achieving the "consent of the governed," would unleash workers' "precious psychic and social energies [by means of] autonomous, self-imposed discipline." FrASER, supra note 47 , at I29; see also Ordway Tead \& Henry C. Metcalf, Labor Relations under the Recovery ACt i6 (I933) (expressing the same idea); TomLINs, supra note 3I, at 8I (attributing a similar view to Leiserson).

220 This theme was persistent in Wagner's statements throughout the period of the drafting and implementation of the Recovery Act and of the NLRA. A Nerw York Times interviewer noted that Wagner "stressed again and again the spirit of cooperation which he deem[ed] essential" to the success of the New Deal program. In that interview, Wagner said "cooperation between employer and employe is not merely urged; it is boldly written into the law," Woolf, supra note 166 , at 6 , and he concluded, "[a] true cooperation, based on mutual understanding, is the only solution for our difficulties." Id. at $x 8$. Wagner told the Senate in 1935 that "cooperation was the only safeguard against social disintegration." 79 CoNG. REC. 94I7 (I935); see also FRASER, supra note 47 , at 127 (attributing same view to other labor progressives, including Commons, Frankfurter, and Hillman). 
tribution of political and economic power could generate a regime of egalitarian communication. Social conflict could be transcended by a cooperative harmony of social groups, "based upon reason rather than upon force."221 Wagner could thus describe the NLRB as:

\begin{abstract}
an agency designed for harmony and mutual concessions. [Congress] established an impartial forum, where employers and employees could appear as equals, where they could look with frank and friendly eyes into each others [sic] problems, where they could banish suspicion and hatred, and where they could sign contracts of enduring peace rather than mere articles of uncertain truce. ${ }^{222}$
\end{abstract}

"[M]utual understanding and trust" would flow from the statutorily encouraged "method of conference, of give and take, of free cooperation."223 Wagner, in short, envisioned a legally-engineered transformation of large-scale enterprises from low-trust, adversarial to hightrust, cooperative organizations. He anticipated economic and psychological consequences very similar to those which more recent analysts of high-trust organizations have elaborated and celebrated. ${ }^{224}$

Wagner's highly cooperationist view of collective bargaining was not merely a progressivist banner unfurled on the occasion of his legislative initiatives. From the end of World War I into the r930s, a cluster of influential labor, engineering, managerial, and academic progressives had assiduously promoted - and practically tested institutions of collective bargaining designed to encourage collaboration and to reshape conflicting group interests. ${ }^{225}$

While many on the left denounced the AFL traditionalists' brand of cooperationism as abject class collaborationism, other progressives and socialists saw unions' participation in joint problem-solving committees as the first step toward worker control and corporatist plan-

22179 CONG. REC. 7565, 7573 (1935), reprinted in 2 LEgisLative HistoRy, supra note 38 , at 234I; see also Robert F. Wagner, WOR Radio Debate (Apr. 28, 1935) (transcript available in The Wagner Papers, supra note 30, at 600 SF 103, Folder 33) (expressing same idea).

222 Wagner, Talk on Labor Relations, supra note 208, at 3-4.

223 Robert F. Wagner, Address at the AFL Convention ro (Oct. ro, 1930) (transcript available in The Wagner Papers, supra note 30, at 546 SM 453); see also Wagner, supra note 173, at 6 (describing "permanent harmony" and "triumph of reason" that would flow from NLRA).

224 See infra section IV.C.

225 The mainstream AFL's embrace of the slogan of labor-management cooperation in the service of industrial efficiency in the I920s - usually ascribed to the desire of the severely debilitated Federation to promote its conservative respectability in managerial circles - is a familiar story. See, e.g., BERNSTEIN, supra note II7, at 85-90; MILTON J. NADworny, SCIENTIFIC MANAGEMENT AND THE UNIONS, I900-1932, at 122 (1955). Less familiar perhaps is the active involvement of progressives and socialists associated with the AFL opposition bloc, together with progressive engineers and social scientists, in some of the leading cooperative experiments of that decade. See infra pp. 1429-30. 
ning in basic production decisions. ${ }^{226}$ The "most famous offspring" of this "paradoxical marriage of progressive unionism and scientific management" was the Baltimore and Ohio Railroad plan. ${ }^{227}$ Under that plan, members of the International Association of Machinists in the railroad shop crafts participated in joint committees with managers at the shop and district levels to revise work practices in the interest of increased productivity. Perhaps more influential still among the progressive reform elite was the cooperative machinery for planning production and organizing work installed in a variety of settings by Sidney Hillman's Amalgamated Clothing Workers of America. ${ }^{228}$ Mary Gawthorpe, an ACWA education director, believed that such machinery was "'bringing to the workers' hands and brains every experience that is necessary to full and complete responsibility and ownership of the industry.'" 229 Wagner assembled leading figures associated with the implementation and advocacy of these models for close collaboration in his legal and political battles on behalf of labor in the I920S and I930s, most notably in his campaign against the yellow-dog injunction ${ }^{230}$ and his fights for section $7(a)$ of the NIRA and for the NLRA itself. ${ }^{231}$

226 See, e.g., MONTgomery, supra note II, at 420-24; Sanford M. Jacoby, Union-Management Cooperation in the United States: Lessons From the I920s, 37 INDUS. \& LAB. REL. REv. 18, 26 (1983).

227 Montgomery, supra note II, at 422; see also David M. VROoman, DANIEL WiLlard and Progressive Management on the Baltimore \& Ohro RaIlroad passim (I99I) (describing the management programs at the $B \& O$ ).

228 See FrASER, supra note 47 , at $13 \mathrm{r}$; HABER, supra note 119 , at 150.

${ }^{229}$ MONTGOMERY, supra note II, at 42 I (quoting Gawthorpe).

${ }^{230}$ In 1928, Wagner orchestrated the successful, landmark legal challenge to a New York state court's injunction barring the AFL from organizing transport workers who had signed yellow-dog agreements with the Interborough Rapid Transit Company. See Interborough Rapid Transit v. Green, 227 N.Y.S. 258 (1928). The centerpiece of the litigation, a 480-page "Brandeis brief," drafted by Wagner, Rifkind, Oliphant, and Hale, see Wagner Brief, supra note I25; Rifkind Interview, supra note 98, at I, was widely disseminated among labor and legal activists and served as a key sourcebook for proponents of the Norris-LaGuardia Act. See HutHMacher, supra note 55, at 65; Ernst, supra note II7, at 270. The Wagner Brief's principal sociological argument was that legal obstruction of collective bargaining impeded collaborative, efficiencyenhancing shop committees that could not succeed without the empowerment of autonomous unions. See Wagner Brief, supra note 125, at 417-28; infra section IV.C. To offer expert support for that proposition, Wagner assembled many proponents of labor-management cooperation, including Taylor Society engineers, see, e.g., NADWORNY, supra note 225, at 122-26, r3r, 133; Otto S. Beyer, The Technique of Cooperation, II BuLl. TAYLOR Soc. 7 (I926); labor economists, see, e.g., LAUCK, supra note I0o, at I7I-73, 30I, 320-346; Paul H. Douglas, Shop Committees: Substitute for, or Supplement to, Trade Unions?, 29 J. POL. ECON. 89, I02-07 (192 I); Sumner H. Slichter, Raising the Plane of Industrial Relations Discussion, II BuLL. TAYLOR Soc. 3, 3-4 (I926); progressive employers, see, e.g., VROOMAN, supra note 227, passim (describing Daniel Willard of the Baltimore \& Ohio); Sir Henry W. Thornton, K.B.E., Management's Appraisal of Principles, Methods and Results, II BuLL. TAYLOR SOC'Y 26, 29 (I926); and sympathetic progressive publicists.

231 Those proponents of cooperationism discussed above at note 230 and other progressive advocates of the new gospel of integrative labor relations - notably, Leiserson, Jacobstein, and 
In I933, after most of the cooperative experiments of the I920S other than those of the Baltimore \& Ohio and the Clothing Workers had evaporated under the heat of the Great Depression and of reasserted managerial prerogatives, the AFL itself quietly dropped its endorsement of cooperative plans. ${ }^{232}$ Yet Robert Wagner and his circle continued to champion the same ideal mode of cooperative labor relations. ${ }^{233}$ It was an ideal that continued to resonate powerfully with Wagner's progressivist commitment to building a cooperative order founded on the principles of scientific planning, substantive freedom, and egalitarian communication and solidarity. Institutionally, that ideal called for independent unionism conjoined with the company-union-like structures of shop committees and similar consultative labor-management bodies. ${ }^{234}$

Hillman - were central players in Wagner's key legislative initiatives to promote collective bargaining. Jacobstein, one of Wagner's closest friends and most influential advisers on his NIRA drafting team in I933, was a personnel manager and economist who had zealously implemented and publicized the ACW's "Rochester Plan" of cooperative labor-management machinery. See Meyer Jacobstein, Can Industrial Democracy Be Efficient? The Rochester Plan, 5 BuLl. TAYLOR Soc. 153, I56-58 (1920); Rifkind Interview, supra note 98. Jett Lauck, also a member of that team, likely deserves substantial credit for ensuring the initial incorporation of labor rights into the Recovery legislation. See VITTOZ, supra note 43, at 89.

During the drafting and defending of the Labor Disputes and Labor Relations bills of 1934 and 1935, Wagner again enlisted the efforts of Beyer, Suffern, Slichter, Hillman and, of course, Leiserson. In the Congressional hearings, they testified generally to the cooperative, integrative promise of collective bargaining, and, more specifically, to the virtues of the Baltimore \& Ohio, Canadian National, and Amalgamated Clothing Workers' schemes of collaboration. See Hearings on S. 2926, supra note 137 , at 286-92 (statement of Arthur E. Suffern), reprinted in I LEGISLATIVE HISTORY, supra note 38 , at 316-22; id. at 220 (statement of Otto Beyer), reprinted in I Legislative History, supra note 38 , at 250; Hearings on $S$. 1958 , supra note 38,176 (statement of H.A. Millis), reprinted in I LEGisLATIve HistoRy, supra note 38, at 1556; id. at 874, reprinted in I LEgislative HistoRy, supra note 38 , at 1556 . Indeed, the arguments of opponents of the Act turned on contested interpretations of the origins and meaning of those cooperative schemes. Walter Gordon Merritt, a leading management theorist, argued that the Act's ban on company unions was mistaken, because the competitive challenge of company unions likely induced labor unions to adopt such cooperative machinery as the Baltimore \& Ohio plan. See Hearings on $S$. 2926, supra note 137 , at rorg, reprinted in I Legislative HISTORY, supra note 38 , at 1057 (brief of Walter Gordon Merritt). At the same time, William Dunne of the Communist Party's Trade Union Unity League denounced the Baltimore \& Ohio efficiency plan, linking it to the AFL's general pronouncements that managerial and labor interests were aligned. See id. at 980 (statement of Walter F. Dunne), reprinted in 1 LEGISLATIVE HISTORY, supra note 38 , at IoI8.

232 See Jacoby, supra note 226 , at 31 .

233 Nor was this ideal confined to the progressive reform elite. Working-class radical activists in the 1930 also continued to deploy the progressivist discourse of scientific management. See, e.g., Gary Gerstle, Working-Class AMERICANism Io-I1, I74-77 (1989).

${ }^{234}$ For recent commentators urging similar combinations of collective empowerment and collaborative structures, see sources cited above in note 26 . 


\section{The Role of Self-Reflexive Interests, Norms, and \\ Trust IN the Political Economy of the Wagner ACT}

The progressive origins of the Wagner Act illuminate the roles of self-interested rationalism and symbolic constructionism in three broad issues of labor law policy and theory. Section A of this Part examines the play of ideology- and interest-transforming processes in the broad origins and impact of the labor legislation. Section B explores how those processes influenced the origins and justification of the key contested substantive provision in the Act, the ban on company unionism. Section $\mathrm{C}$ analyzes Wagner's understanding of the instrumental and symbolic dynamics of labor-management cooperation, and aligns and elaborates Wagner's view with more recent theories of workplace cooperation and trust. As to each of these issues, the common theme of Wagner's political economy and its current variants is that actors' preferences, interests, norms, and broader dispositions of trust are endogenous to institutional practices and discourse. ${ }^{235}$

\section{A. Processes of Interest-Transformation in the Origins and Impact of the Act}

Processes of ideology- and interest-transformation shaped the origin and impact of the Wagner Act in three broad ways. The major relevant social groups entered the New Deal period with historically contingent interpretive frameworks that informed their subjective political interests. The ensuing legislative initiatives had a reciprocal effect on the perceptions and interests of those groups. Finally, that transition in social consciousness was mediated by the ongoing political contests of policy entrepreneurs. A particularly important elite debate focused precisely on the impact of legal symbols and sanctions on workers' and managers' consciousness.

I. Contingent Ideological Frameworks. - Much traditional economic theorizing - including the public choice explanation of the Wagner Act - assumes that unions perceive and pursue an interest in government intervention to aid their pecuniary rent-seeking. ${ }^{236}$ Compelling recent theoretical and empirical writing suggests, however, that political interests (or any other "self-interests" ${ }^{237}$ ) cannot be reli-

235 See note I above for explanations of the concepts of "exogenous" and "endogenous" preferences, interests, and perceptions, and the relationship of those concepts to self-interested, instrumental-rationalist theories of legislation and economics.

${ }^{236}$ See sources cited supra note 4. Similarly, some traditional Marxist thinking ascribes objective political interests to social classes or class segments. See, e.g., STEven LuKES, PowER: A RADICAL VIEW 22 (I974); Isaac D. Balbus, The Concept of Interest in Pluralist and Marxian Analysis, I POL. \& SOC'Y I5I, 161, I67 (1971).

237 "Self-interest is an empty term, until you have defined what a self is and the kind of things it is interested in." James Boyle, Is Subjectivity Possible? The Post-Modern Subject in Legal Theory, 62 U. CoLo. L. REv. 489, 509 (I991). 
ably ascribed to a group apart from the group's contingent judgment of its interests; and the group's historically received, contested ideology shapes that judgment. Work in discourse theory, cognitive psychology, and the sociology of knowledge demonstrates that language and other symbolic systems, discursive practices, and ideological maps are not merely communicative, but in part constitutive, of individual and group perceptions, interests, and identities. ${ }^{238}$

This is not to suggest that subjective political interests are fully constructed by (and therefore conflated with) a historically contingent "political discourse," as some Nietzschean post-modernists have proposed. 239 Nonetheless, the post-modernist denial "that the mere occupancy of some place within society will automatically supply you with an appropriate set of political beliefs and desires" is indisputable. ${ }^{240}$ Subjective political interests and perceptions are generally the (highly contextual) joint product of actors' inherited discursive frameworks, socio-economic position, the political circumstances they face, and their own creative, often intersubjective, deliberation. ${ }^{241}$

The AFL's ideological occlusion and political passivity - discussed in Part $I I-$ is a clear illustration that neither the "interests" sought by social groups, nor the political will to satisfy them, are objectively or ahistorically given. That the "interests" of organized labor in the early I930s were open to a wide range of specifications is well demonstrated by the concurrent experiences of the AFL and the Amalgamated Clothing Workers, which was not affiliated with the AFL prior to the New Deal. While the AFL failed to play a more dynamic role in early New Deal labor policy in part because of its voluntarist ideological heritage, the ACW was equally hamstrung by the passionately socialist political "interests" held by much of its membership. ${ }^{242}$

${ }^{238}$ For a recent summary of this vast literature, see Peggy J. Miller \& Lisa Hoogstra, Language as a Tool in the Socialization and Apprehension of Cultural Meanings, in NEw Directions in Psychological ANTHRopology 83, 83 (Theodore Schwartz, Geoffrey M. White \& Catherine A. Lutz eds., I 992). Among legal theorists, the interest- and identity-constituting nature of (legal and other) categories of thought and discourse is well presented in KELMAN, cited above in note 8, at 243; Martha Fineman, Dominant Discourse, Professional Language, and Legal Change in Child Custody Decisionmaking, ror HaRv. L. REv. 727 passim (1988).

${ }^{239}$ This extreme position is presented, not without ambiguity, in BARRY HINDEss \& PAUL Hirst, Mode of Production and Soclal Formation 9-33 (1977); ERnesto Laclau \& Chantal Mouffe, Hegemony and Socialist Strategy I05-45 (I985).

240 TERRY EAGLETON, IDEOLOGY 206 (199I).

241 Terry Eagleton, for example, asks us to "[i]magine an objective location within the social formation known as third galley slave from the front on the starboard side." Id. Even if one were unwilling to embrace Eagleton's declaration that someone - anyone - occupying that social location has an "objective interest in emancipating himself," id. at 207 (emphasis added), one can still predict that the galley slave is likelier subjectively to experience such an interest under conditions of diminished secondary socialization by his superiors, and that such a subjective interest is likelier to be embraced by the "League of Escaped Galley Slaves" than by the Emperor and Magnates. See id. at 206.

${ }^{242}$ The ACW played a limited organizational role, even though its "new unionism" of the 
What was true for organized labor was also true for business groups, as several of the leading historical studies of I930s managerial policy attest. Steven Fraser's study of New Deal political economy has brought to light the "new, rising milieu of mass-market-oriented producers, distributors, and financiers" who, in the I930s, showed "more amenab[ility] to 'Keynesian' approaches to shoring up aggregate demand," including more willingness to contemplate forms of purchasing-power-enhancing collective dealing between labor and management.243 Nonetheless, Fraser makes clear that the emerging Keynesian politics - including the new labor policy - was actually fashioned and won primarily by a reform elite "who stood outside the marketplace."244 Fraser's acute documentation shows that the new "industrial profile" translated into neither a "political action committee of businessmen" nor "the sort of shadow government that began to gather in the corridors of the Democratic party and around the statehouse in Albany."245

Consistent with this analysis is Howell Harris's portrayal of managerial groups' strategic choices to promote the disparate policies of "persistent anti-unionism," "realism," or "progressivism" in labor-management relations. ${ }^{246}$ Case studies of the rubber, textile, auto, and steel industries show that comparable enterprises in the same industry supported such radically different labor policies, stemming from individual firm histories and cultures of labor relations and the idiosyncratic personalities and philosophies of key decisionmakers of each firm. ${ }^{247}$ Business historian Daniel Nelson concludes that such contin-

I920s served as a model for New Deal political entrepreneurs including, of course, ACW President Sidney Hillman. Hillman played a leading personal, entrepreneurial role as an early New Deal strategist. See FrASER, supra note 47 , at 280 . The ACW was later brought into the New Deal fold, in part as a result of the shift in workers' interests and preferences induced by New Deal policies and pronouncements - another confirmation that group interests are not pre-politically fixed. See infra pp. 1335-39.

243 FRASER, supra note 47 , at 264.

244 Id. at 266 .

245 Id.

In the mass, businessmen were scarcely more politically articulate or active than other functional groups, oscillating between apathy and political routine, often informed by nothing more elevated or enlightened than habit and tradition, or the myopia of selfinterest. . . . [T] he newly empowered "Keynesian" elite enjoyed at best limited support among the great mass of entrepreneurs and practically no support among older industrial groups.

Id.

246 Howell J. Harris, The Right to Manage 23-37 (1982).

247 See, e.g., GerSTLE, supra note 233 , at I05-II (textiles); Steve Jefferys, "Matters of Mutual Interest": The Unionization Process at Dodge Main, 1933-1939, in ON THE LINE: ESSAYS IN THE HISTORY OF AUTO WORK IOO, I2I-24 (Nelson Lichtenstein \& Stephen Meyer eds., r989) (auto); Daniel Nelson, Managers and Nonunion Workers in the Rubber Industry: Union Avoidance Strategies in the r930s, 43 INDUS. \& LAB. REL. REv. 4I, 4I-5I (I989) (rubber); Richard C. Wilcock, Industrial Management's Policies Toward Unionism, in LABOR AND THE NEW DEAL 275, 300-302 (Milton Derber \& Edwin Young eds., 1957) (steel). 
gency - which was typical of "much of American industry" - demonstrates that "corporate executives were not political symbols, but individuals confronting complex problems in settings of extreme uncertainty."248 The fallacy of reductionist assumptions about the formation of subjective political interests applies not only to elite economic groups, but also nonelite actors, as discussed in the next section.

2. The Perceived and Actual Symbolic Effect of the New Deal Labor Legislation. - Wagner's understanding of consent and cooperation, discussed in Part III, registered a convergence between the conditions necessary to render worker consent "genuine" in a normative sense and the conditions necessary to elicit subjective worker acquiescence in a purely descriptive sense. Wagner's understanding of the relationship between normative and descriptive consent reflected a nuanced view of the relation between legal symbolism and worker consciousness - a view that again interwove major strands of progressive thought.

Wagner's speeches and writings at times intimated a characteristically pragmatist and realist tendency; he seemed to conform his normative evaluation to existing fact, his "ought" to an "is."249 In his I937 lecture at Yale Law School, he proposed that "while the facts do not always govern what the law is, they at least determine what the law ought to be."250 Applying this proposition, the "factual basis"251 for the Wagner Act's normative premise that collective bargaining would yield genuine consent might be that workers would subjectively acquiesce in the authority relations of the mass production workplace only if they were afforded collective bargaining. ${ }^{252}$ What the industrial worker subjectively took to be the dictates of social justice would be enshrined by the legislature in the name of objective justice.

But this initial interpretation ascribes to Wagner a too simple, reductive view of the relation between legal norm and social consciousness - and inaccurately implies that his conception of objective social justice was driven simply by the instrumental purpose of ap-

248 Nelson, supra note 247 , at 50.

249 See Morton J. HoRwitz, The Transformation of AMERICAN LAW, i870-1960, at 2I I-I2 (I992) (explaining the realist tendency to conflate "ought" and "is"); MORTON G. WHITE, Social Thought IN AMERICA 212-214 (1952).

250 Wagner, supra note 129 , at 2.

251 Id. at 21 .

252

[The workers] believe with every fibre of their being that their part in developing our great national wealth entitles them to be heard. . . . They are sold upon the proposition that the worker's right to some voice in the business from which he draws his bread, it is [sic] fundamental as his right to some voice in the government from which he gets his laws.

Wagner, Labor Institute, supra note 208, at 5-6; see also Wagner, Talk on Labor Relations, supra note 208 , at I-2, 8-II. 
peasing workers' subjective discontent. ${ }^{253}$ To the contrary, true to his Progressive Era roots, Wagner took the moral objectivity of workers' substantive freedom as axiomatic. ${ }^{254}$ In his Yale speech he went on to say that the relevant "changing facts" to which the law should "cling"

embrace not only economic statistics. They embrace industrial law and popular psychology as well. They include the mass of decisions already rendered and statutes already passed. They include the crystallized attitude toward these laws on the part of workers, employers and the public. Insofar as these group attitudes toward the law have worked their way into the fabric of our institutional life, they are just as much facts to be dealt with as the number of the unemployed. 255

Law must conform to facts; however, social facts, including popular consciousness, were not pre-legal but were shaped by prior - and could be reshaped by future - legal interventions. In short, Wagner's understanding of the relation between legal norm and social consciousness was not reductionist but dialectical.

In setting out this abstract view in his 1937 speech, Wagner generalized a historically pivotal experience on which he had frequently commented since the enactment of section $7(a)$ of the Recovery Act in 1933. While that provision effectively lacked any enforcement mechanism, its encouragement of militant worker action had been stunning. ${ }^{256}$ Along with many other

${ }^{253}$ For an attack on such appeasement, see Epstein, cited above in note 4, at r404-05. The Wagner Act - even on this limited interpretation of Wagner's understanding of law and fact - therefore demonstrates that the realists' conflation of "ought" and "is" did not always embody a politically conservative bias, as Horwitz sees in Llewellyn's factual appeal to extant business norms to fashion the Uniform Commercial Code. See Horwitz, supra note 249, at 2 II-I2. It all depended on the "is" to be codified. For a progressive pragmatist like Wagner, the "is" was a dynamic "process of becoming" that included oppositional "facts" such as workers' aspirations.

254 Although legal realists such as Hale and institutionalist economists such as Commons believed that, as a descriptive matter, coercion was an inevitable element of contractual relations regardless of relative bargaining power, see supra note 124, they were hesitant to take the normative leap overtly to demarcate legitimate and illegitimate coercion, false and genuine consent, in the way Wagner did. On the tension between ethical relativism and pragmatic political action in institutionalist and legal realist thought, see Daniel Ernst, Common Laborers? Industrial Pluralists, Legal Realists, and the Law of Industrial Disputes, 1915-1943, I I LAW \& HIST. REv. (forthcoming, Spring 1993). Wagner's ethical objectivist stance was clearly rooted in an abiding Progressive Era faith in "the reality of a common good." DANIEL RoDgers, CONTESTED TRUTHS 182 ( 1987 ).

255 Wagner, supra note 129 , at 2-3.

256 In the months after the enactment of $\S 7(a)$, workers flooded into labor unions, often spontaneously forming new locals. The AFL issued charters to 3,537 new federal (i.e. industrial) locals between June and October of $\mathrm{I} 933$ alone. As employers resisted union demands for recognition, strikes in 1933 rose to their greatest level since I $22 \mathrm{I}$. The following year witnessed an even larger strike wave, including violent upheavals in Toledo, San Francisco, and Minneapolis which, to contemporary observers, approached the dimensions of civil war. By the end of I934, organized labor had regained almost as many members as it had lost between I923 
observers, ${ }^{257}$ Wagner attributed that upsurge in significant part to the symbolic effect on worker consciousness of the legislative endorsement of the right to collective bargaining. ${ }^{258}$ Looking back in 1935, Wagner wrote that section 7 (a) "drove its appeal to the conscience and hopes and aspirations of nameless men and women from coast to coast."259 When Roger Baldwin of the American Civil Liberties Union opposed the NLRA on the ground that it would "lull[ labor," Wagner pointed to the section 7 (a) experience as proof that, to the contrary, it would be "a galvanizing force." 260 The historical evidence confirms Wagner's perception. ${ }^{261}$

and 1933, an accomplishment that would have been exceeded had the sluggish AFL been prepared for the upsurge in worker militancy. See BERNSTEIN, supra note 79, at 172-73, 21798; JACOBY, supra note I9, at 224.

257 See, e.g., Sumner H. Slichter, Labor Under the National Recovery Act, I2 HaRv. Bus. REV. I42, 148 (1934).

258 Wagner's chairmanship of the NLB - set up precisely to respond to the unrest triggered by the Act - had exposed him to the way that workers' desire for collective bargaining had been sparked by the entitlement symbolized by $\S 7(a)$. (The revival of the labor movement in 1933-34 was not, of course, attributed wholly to Section 7(a). Among the other forces thought to be at work were the recovery in employment due to enhanced business confidence after the passage of the Recovery Act, the organizational efforts of militant, often leftist activists, and workers' pent-up frustration after years of depression.) This was one of the crucial pragmatic lessons of the "tremendous experiment" of the NRA. Wagner, supra note r79, at i2; see also Robert F. Wagner, WEVD Radio Address I-2 (June 25, 1937) (transcript available in The Wagner Papers, supra note 30 , at 600 SF I03, Folder 38) (expressing same idea). Indeed, even before he witnessed the "inspirational," $i d$., and "galvanizing" impact of $\S 7(a)$, Wagner recognized that legal pronouncements could shape workers' desire. Letter from Sen. Robert F. Wagner to Roger Baldwin, Director, American Civil Liberties Union I (Apr. 5, 1935) (hereinafter Wagner, Baldwin Letter] (on file in The Wagner Papers, supra note 30 , at $700 \mathrm{LA} 7 \mathrm{I} 7$, Folder 37). In his defense of the Norris-LaGuardia Act's proscription on injunctions to enforce yellowdog contracts, Wagner explained that the prior legalization of collective organization in state law - amounting to a social pronouncement that unions were legitimate - had the effect of "whet[ting] the desire to join" unions, in the face of employers' continuing private obstruction of organizing by the yellow-dog contract. 75 CoNG. REc. 4916 (1932) (quoting Walter Gordon Merritt). For Wagner, of course, the entire Recovery Act was premised on the expectation that a new cooperative ethos could be implanted in the "hearts and minds" of the citizenry. See Wagner, supra note 162 , at 4 . More generally, Wagner believed that the success of the "controlled experiment" of reform legislation depended on the degree to which it induced citizens to "come forward in eager participation." Wagner, Catholic Charities, supra note 162, at 4.

${ }^{259}$ Robert F. Wagner, Speech at Madison Square Garden 10 (May 23, 1935) [undelivered] (transcript available in The Wagner Papers, supra note 30, at 600 SF I03, Folder 34).

260 Wagner, Baldwin Letter, supra note 258 , at $\mathrm{x}$.

261 See supra note 256. "The strike wave of mid-r 933 and the one in the spring and summer of 1934 were inspired by the rhetoric if not the actual achievements of the new regime; again and again the Blue Eagle and $7 a$ were invoked to sanction acts of resistance and rebellion." Fraser, supra note 47, at 329 (emphasis added); see also LIZABETH COHEN, MAKING A NEW DEAL: INDUSTRIAL WORKERS IN CHICAGO, I9r9-r939, at 278, 303 (1990) ("Although the NRA 'had no teeth,' . . . it unleashed a torrent of pent-up enthusiasm for organization . . . ."); Jefferys, supra note 247 , at IOI (illustrating the impact of $\$ 7(a)$ on labor relations in the auto industry). Popular consciousness of the legislation was promoted by the "Blue Eagle" campaign launched by the public-relations-obsessed head of the NRA, General Hugh Johnson. See Hugr 
In Wagner's view, once workers had, in part under the inspiration of section 7(a), come to "believe with every fibre of their being"262 in their right to collective bargaining, there was no turning back from the government's commitment to secure that entitlement. In March, I934, Wagner warned that "increasing unrest is inevitable if the hopes inspired by the Recovery Act are frustrated."263 The desires whetted by the "pledge made by the government" in section 7 (a) would be further stimulated, and simultaneously satisfied, by the entitlements of the NLRA. 264

To the progressive mind of the r93os, the lesson of section 7 (a) that workers' subjective interests and sense of entitlement were (in part) endogenous to legislative pronouncements - was easily assimilated. That popular consciousness was conditioned by social circumstances and susceptible to deliberate "engineering" were staples of

S. Johnson, The Blue Eagle from EgG to Earth I58-408 (1935). Labor handbills across the country proclaimed that the United States government had endorsed collective organizing, and workers flocked into union locals named "NRA" and "Blue Eagle." See BERNSTEIN, supra note 79, at 37-125; SCHLESINGER, supra note 50, at I39. In November, 1933, George Johnson of the Endicott Johnson Company warned his son, who managed the family business, to take special care in attending to worker grievances because their nonunion workforce was "thoroughly wrought up by that thing called the 'Seventh Article' in the Recovery Act." Gerald Zahavi, Negotiated Loyalty: Welfare Capitalism and the Shoeworkers of Endicott Johnson, 1920-1940, 71 J. AM. HIST. 602, 6I4-25 (1983) (quoting letter from George F. Johnson to George W. Johnson, Jr., and Charles F. Johnson, Jr.). Similar instances are recounted in CoHEN, cited above, at 304; FrASER, cited above in note 47, at 292; and GerSTLE, cited above in note 233, at 128 , I30 n.7.

262 Wagner, Labor Institute, supra note 208 , at 5 .

263 HUTHMACHER, supra note 55, at 192 (quoting Wagner); see also Robert F. Wagner, Wagner Challenges Critics of His Act, N.Y. TIMEs, July 25, I937 (Magazine), at I ( ${ }^{\text {[T }}$ T]hose goaded into fighting for . . . elementary social rights are [not] amenable to ordinary restraints."); 79 CoNG. REc. 237 (1935) (statement of Sen. Wagner), reprinted in I Legislative HistoRy, supra note $3^{8}$, at $\mathrm{I}_{3} \mathrm{I} 2$ (" $[\mathrm{E}] \mathrm{m}$ ployees find it difficult to remain acquiescent when they lose the main privilege promised them by the Recovery Act.").

${ }^{264}$ See Wagner, supra note 259, at 20, 23-25. In the language of his Yale speech, the law would have to "cling" to a brute fact of "popular psychology" - the fact that workers believed deeply in their right to collective organization. But that belief was itself a "crystallized attitude" generated in part by the earlier enactment of $\S 7(a)$, and the passage of the NLRA would again act as such a "galvanizing force." The "inspirational value" of the NIRA would thus "stand] as a permanent contribution toward economic democracy upon the American continent." Wagner, WEVD Radio Address, supra note 258 , at I (emphasis added). This account of Wagner's understanding of the way that legislative pronouncements stimulated worker attitudes and behavior is consistent with the new labor historiography ascribing central roles to state policy and cultural transformation in the rise of the industrial labor movement in the I930s.

The great strike waves and daring forays into the heart of heavy industry of the midI930s seem practically inconceivable without the prior sea change in mass political attitudes inspired first by $7 a$ and then by the legislative breakthroughs [including the NLRA] of the 'second New Deal,' and registered with irresistible force in the Democratic landslides of $\mathrm{r} 934$ and $1936 . "$

Fraser, supra note 47 , at 329 ; see also Gerstle, supra note 233 , at $\mathrm{r} 30$ \& n.7, 180-81 (documenting workers' assimilation of legal-administrative discourse). 
progressive psychology. ${ }^{265}$ The salient experiences of wartime propaganda and of nascent mass advertising, put the manipulable, fictive qualities of public attitudes at the center of the social criticism of such thinkers as Walter Lippmann, Harold Lasswell, and Thurman Arnold in the I920s and I930s. ${ }^{266}$ By contrast, such "communitarian" progressives as Charles Horton Cooley, Josiah Royce, and John Dewey saw positive, democratic possibilities in the social construction of human desires and interests, ${ }^{267}$ along the general lines of the cooperativist society that Wagner sought to create. 268 Wagner's view of law and society thus suggests that what, according to R.J. Lustig, was true for progressives during the Progressive Era remained true in the New Deal: "[T]he new frontier for national effort . . . turns out to have been the minds of the nation's citizens."269

In his broadest rhetorical moments, Wagner depicted industrial democracy through collective bargaining as the inevitable working out of the teleology of freedom. ${ }^{270}$ But his more elaborate analyses make plain that the means for realizing the evolution toward objective worker interests and natural social justice would reflect Holmes's pragmatist credo: "The mode in which the inevitable comes to pass is

265 Even John Dewey, the progressive thinker most hostile to paternalist suffocation of individual voluntarism, evaluated "specific social arrangement[s]" in light of their "creation of changed personalities." I2 JOHN DEWEX, Reconstruction in Philosophy, in THE MIDDLE WoRks, I899-I924, at 77, I92 (Jo Ann Boydston ed., 1982) (1920).

266 See, e.g., Thurman W. ARnold, The Folklore of CAPitalism 5-82, $118-84$ (1937); Harold D. Lasswell, Propaganda Technique in the World War i85-213 (1927); WalTER LIPPMANN, PUBLIC OpINION 7-32 (1922). Wagner read and corresponded with Lippmann, see, e.g., Letter from Sen. Robert F. Wagner to Walter Lippmann (May 26, 1934) (on file in The Wagner Papers, supra note 30, at 694 LA 715, Folder 8), and was advised by Arnold. See supra note 127 .

267 Dewey retained faith that egalitarian communication could sustain communitarian democracy. See supra p. I4Ig; see also Charles H. CoOley, Soclal Process 351-94 (1918) (arguing for "rational control of human life" as a means of establishing an intelligent democratic process); JOSIAH ROYCE, THE PHILOSOPHY OF LOYALTY 228-48 (IgO8) (arguing that training people in loyalty will enhance participatory democracy). For a useful discussion of the communitarian progressive view that interests and desires were endogenous to communities, see Price, cited above in note 218 , at $1663-73$.

268 If Dewey's and Wagner's political philosophies converged in their general commitments to cooperative, democratic interest-formation, they diverged at the programmatic level, at least regarding the NRA. Dewey vehemently objected to the degree of centralized corporatism embodied in the NRA. He did, however, support the NLRA. See WeSTBROOK, supra note I61, at $440-4 \mathrm{I}$.

${ }^{269}$ LUSTIG, supra note I49, at I48; see also id. at I94 ("Progressive respect for human nature came down to a decision to resolve social conflicts by controlling the conditions in which psyches developed and symbols emerged.").

270 See 79 CONG. REC. 7565 (1935) (statement of Sen. Wagner), reprinted in 2 LEGiSLATIVE HrSTORY, supra note 38 , at 232 ("It is the next step in the logical unfolding of man's eternal quest for freedom."); 75 CoNG. REc. 4918 (1932) (statement of Sen. Wagner) (arguing that collective bargaining would produce "the kind of men Divine Providence intended us to be"). 
through effort."271 That is, the inexorable evolution toward industrial democracy was a deliberately engineered evolution, an instance of "Reform Darwinism," to use an apt characterization of the progressive reform vision. ${ }^{272}$ The path of the law would help align workers' subjective sense of the legitimacy of workplace governance with what Wagner took to be the objective conditions of genuine consent. Through both its instrumental and symbolic effects, then, the new labor policy would help create the industrial labor movement in the image of the progressive vision of objective worker entitlements and social justice. ${ }^{273}$

3. Programmatic Debate Among Progressive Policy Entrepreneurs. - Economists model legislation as a process in which legislators act either as agents or brokers for the interests of social groups, or as sellers of political benefits to interest groups. ${ }^{274}$ In the latter model, payments by interest groups "take[ the form of campaign contributions, votes, implicit promises of future favors, and sometimes outright bribes."275 Public-choice theorists thus presume that legislators act in their relatively narrow self-interest, which includes their desire for reelection and their pecuniary interests. ${ }^{276}$

271 GOLDMAN, supra note I88, at 79 (quoting Justice Holmes).

272 On the concept of Reform Darwinism, see GoldMAN, cited above in note 188, at 72-81; LUSTIG, cited above in note 149 , at 158 (describing how progressives, outflanking conservative Social Darwinists, argued that "the process [of social evolution] could be made more efficient and humane if the adaptation were conscious"); and Hovenkamp, cited above in note 152 , at $671-85$.

273 It is important neither to overstate nor to decontextualize the claim for the impact of legislative symbolism on worker consciousness. Wagner believed that workers' sense of entitlement to collective bargaining flowed not just from legislative symbolism but from democratic commitments and other norms in the general political culture and from workers' daily experience of subordination and solidarity. See supra note 208; infra pp. I456, 1458 . And the symbolic entitlement of workers to collective bargaining rights was but one symbolic legal-political pronouncement among the many that emanated from New Deal policy and account in part for the "sea change" in workers' political and industrial attitudes. FRASER, supra note 47 , at 329; see also COHEN, supra note $26 \mathrm{I}$, at 285,289 (expressing same idea); GERSTLE, supra note 233 , at I79 (same). To tell the full story of the symbolic impact of labor legislation, one would have to identify more comprehensively not just the phase of symbolic production (i.e. legislation), but also the means of symbolic transmission (e.g., government's, labor organizations' and the mass media's dissemination of information about the legislation); the social contexts of symbolic reception (i.e. the settings in which workers themselves discussed and interpreted the legislative symbols); and the historically contingent importance of legislative symbolism relative to myriad other cultural forces affecting worker consciousness. For useful frameworks for analyzing this process, see W. Russell Neuman, Marion R. Just \& ANn C. Crigler, Common KNowledge: News and the Construction of Political Meaning 3-22, 60-77, 96-122 (1992); and John B. Thompson, Ideology AND Modern Culture 28-73, 272-327 (Iggo).

274 For the agent or broker model, see RoBERT E. MCCORMICK \& ROBERT D. TOLLISON, Politicians, Legislation, AND the ECONOMY: AN INQUIRY INTO the INTEREST-GrouP Theory of Government 7-II, 29-60 (I98I). For the seller model, see William M. Landes \& Richard A. Posner, The Independent Judiciary in an Interest-Group Perspective, I8 J.L. \& ECoN. 875, 877 (I975).

275 Landes \& Posner, supra note 274 , at 877 .

276 For one leading analysis presuming narrow self-interest-maximization by political actors, 
While there is much explanatory power in the linkage between private interests and the self-interest of policy-makers, 277 the historical evidence suggests, in the case of the Wagner Act, a substantial independent role for programmatic debate and creativity among the relevant political entrepreneurs. ${ }^{278}$ That is, just as the "interests" of private interest groups are not objectively pre-determined but are shaped in part by contingent ideological frameworks, the same is true of the "interests" of political elites. Others, of course, have criticized public choice models for their neglect of the importance of the ideological objectives of private or public actors. ${ }^{279}$ This Article's account of the Wagner Act, however, highlights the endogeneity and selfreflexivity of ideology and interests within the legal-political process itself. Among the politically articulate, newly empowered reform elite of the r930s, ideological positions on the labor question were varied

see Fred S. McChesney, Rent Extraction and Rent Creation in the Economic Theory of Regulation, I6 J. LEGAI STUD. IOI, I03-06 (I987). That presumed motivation, of course, implies that legislators will by and large act as the transmission belt for the interests of effectively organized groups or, where the saliency of a particular issue overcomes the public's rational ignorance of political affairs, for the interests of voters. For some leading public choice theorists, of course, the Wagner Act reflected organized labor's lobbying power, transmitted through the narrow self-interest of a Congressional majority. Political theorists of the "corporate liberal" school rely on the same reductionist assumption that political actors are the agents or suppliers of private interest groups, but reach the antipodal conclusion about the identity of the buyers and beneficiaries of the Wagner Act. Senator Wagner and allies like John Commons, Lloyd Garrison, and Francis Biddle are portrayed as quintessential corporate liberals serving the longterm interests of the capitalist class. See, e.g., Domhoff, supra note 65 , at $170-72,178$. Even those neo-Weberian state theorists who grant political actors substantial autonomy from private interests tend to presume that the interests of "state managers" can be read from their institutional position in state bureaucracies or legislatures. See, e.g., BLOCK, supra note 57 , at 54,67 . In such theories, the interests of political actors again presumptively lie in retaining or expanding state power or securing personal incumbency and perquisites.

277 See supra pp. $\times 396-97$. Although this Article's account of the Wagner Act criticizes the interest-group, deal-making model, it by no means rules out the Gramscian thesis that elite actors' ideological frameworks are influenced by a dominant culture itself conditioned by powerful material forces such as business and organized labor. See T.J. Jackson Lears, The Concept of Cultural Hegemony: Problems and Possibilities, 90 AM. HIST. REv. 567, 568 (1985); supra note 29. However, this Gramscian approach to political culture, even with its traces of functionalism, is a far cry from the market-like model of legislative deals sketched above. American political culture in the I930s was sufficiently multivocal, and the alignment of interest-group forces sufficiently fluid, to allow political entrepreneurs a substantial degree of freedom in drawing on (and altering) the extant repertoire of ideological understandings of labor relations, including elements that were distinctly "oppositional" to dominant economic groups.

278 See supra Parts II, III; infra section IV.B. David Plotke makes this general point well, though not in the context of a critique of public choice theories of politics, and without reconstructing the debates among political entrepreneurs that shaped the crucial provisions of the NLRA, including $\$ 8(a)(2)$. See Plotke, supra note 42, at II 7-26.

279 See, e.g., Daniel A. Farber \& Philip P. Frickey, Law and Public Choice: A Critical Introduction 29-33 (I991); Mark Kelman, On Democracy-Bashing: A Skeptical Look at the Theoretical and "Empirical" Practice of the Public Choice Movement, 74 VA. L. REv. I99, 205-23 (I988); Mark J. Roe, A Political Theory of American Corporate Finance, 91 Colum. L. REv. Io, 32-45 (I99I). 
and up for grabs. The debate over labor policy, in turn, focused on the extent to which the subjective ideologies and interests of private groups were susceptible to transformation through legal and political engineering, symbolic and instrumental. In other words, theorists' recognition that the ideologies of relevant actors play an important role in political outcomes is just the beginning of the story. If ideology and interests are malleable, and especially if the actors themselves recognize that fact, then institutional and discursive contests (including legal contests) over subjective interests and perceptions become central to political processes and outcomes and require theoretical attention. Politics becomes an arena not only for maximizing or brokering interests (whether narrow pecuniary interests or broader "ideological" interests) but also for the transformation of ideology and interests. ${ }^{280}$

In this light, the general theory that explains labor legislation as the political deployment of symbolism to pacify a disruptive working class $^{281}$ is broadly accurate in the case of the New Deal legislation, but requires elaboration. That theory, by positing that the legalpolitical order will yield the symbolic output necessary for restoring labor peace, risks falling into the functionalist fallacy. ${ }^{282}$ The causal mechanism that produces the "functional" symbolism in response to worker disruption needs to be specified. The above analysis suggests that (I) that mechanism cannot be taken for granted but rather turns on the interpretive framework of the relevant political elite facing the workplace unrest, and (2) that framework need not call simply for maximum symbolic pacification. As detailed in the previous section, Wagner's ideology was more nuanced than a simple labor-pacification position. He believed that passage of the NLRA, like the enactment of the NIRA, would not simply palliate worker discontent but would, in his words, "galvanize" and "inspire" workers' collective rebellion by reinforcing their sense of entitlement, even while channeling that rebellion into goals and institutional structures concordant with the progressives' ultimate vision of labor-management cooperation. ${ }^{283}$

${ }^{280} \mathrm{Cf}$. Richard H. Pildes \& Elizabeth S. Anderson, Slinging Arrows at Democracy: Social Clioice Theory, Value Pluralism, and Democratic Politics, go Colum. L. Rev. 2121, 2 I95 (1990) (elaborating a positive and normative defense of political transformation of community selfdefinition); Cass R. Sunstein, Preferences and Politics, 20 PhIL. \& PUB. AFF. 3, I6 (I99I) (elaborating a normative defense of political transformation of preferences).

281 See Hyde, supra note 7, at $431-48$.

282 In the functionalist fallacy, a social phenomenon (here, the pacifying legal symbolism) is "explained" by its function or effect. That is, it is explained by a posterior event, here, the quieting of labor unrest, rather than by its actual causal origins - the political forces responsible for fashioning and transmitting the legal symbol. See Jon Elster, Making SenSE of MarX 27-29 (I985). I do not mean to attribute this fallacy to Hyde himself in his applications of the theory of symbolic pacification. To the contrary, Hyde has been a steadfast critic of functionalist explanation. See Hyde, supra note 7, at 427 n.156; Hyde, supra note 8, at 420-22.

283 This is consistent with Hyde's prediction that "when pressure is being placed on man- 
Thus, in the framing and passage of the Act, the reform elite did not act merely as an uncreative courier of an existing package of "precedents" under the "impetus" of labor and radical unrest, as some commentators have intimated. ${ }^{284}$ Ideological and political conflict among elite political entrepreneurs decisively shaped the precise substantive content of the New Deal labor legislation and the future path of American labor relations. The importance of such conflict, which included debates over the plasticity of worker consciousness, was apparent in the crucial contest over the appropriate regulatory response to company unionism. ${ }^{285}$

\section{B. Worker Interest-Formation and the Justification for the Ban on Company Unions}

I. The Puzzle of the Justification for the Company Union Ban. Wagner's justification for banning company unionism must ultimately be understood in light of the primacy that he assigned to achieving workers' genuine consent to workplace authority. For Wagner, as a normative matter, the company union failed to provide sufficient collective empowerment to eliminate duress and achieve workers' democratic consent to the system of workplace governance in the largescale enterprise. ${ }^{286}$ And because the objective conditions for normative consent and for descriptive acquiescence converged, company

agement by spontaneous or unorganized workers, concessions will be made" by political elites "to build [unions] up as a restraint on employee action, or simply to institutionalize the conflict." Hyde, supra note 7 , at 440 . On the other hand, the electrifying effect of New Deal labor policy on the growth of the industrial labor movement deviates from Hyde's prediction that "one would anticipate limited direct behavioral effects apart from the short-range goal of conflict suppression," id., and perhaps also from his prediction that "elites would, to the extent possible, offer concessions which combine the maximum symbolic pacificatory value with the minimum inroads on employer control," id. at 439. A regime of proportional representation and permissible company unionism may have better fit the latter criterion than did the NLRA but was rejected after entrepreneurial contest. See supra section II.D; infra section IV.B.

284 See, e.g., Goldfield, supra note 67 , at 1269.

285 The spirit of this analysis is captured in Robert Gordon's response to legal structuralists:

The structuralists would . . . respond that legal structures, because of their indeterminacy, can't be expected to connect in any predictable fashion with the interests of any particular class or group. . . . One could concede this point to the structuralists and still ask them to embed their story in a narrative context that would at least supply subjects and occasions to the narrative to show that it is human beings with reasons and motives, not disembodied Spirits, who drive the manufacture of legal concepts: Who pushed which arguments on what occasions and why? What happened to set off the arguments? What happened to destabilize previously stable conventions?

Gordon, supra note 8 , at II 9 .

286 See 78 CONG. REC. 3443 (1934) (statement of Sen. Wagner), reprinted in I Legislative HISTORY, supra note 38 , at 15 (arguing that company-dominated union "makes a sham of [the] equal bargaining power" necessary for workers "to exercise their proper voice in economic affairs"). But see Hearings on S. 2926, supra note 65, at 725 (statement of Arthur Young, Vice President, U.S. Steel), reprinted in I LEGISLATIVE HISTORY, supra note 38 , at 763 (arguing that consent could be achieved with company unions). 
unionism also failed to achieve cooperation and subjective legitimation in the firm and the polity. ${ }^{287}$

Nonetheless, when viewed within the overall regulatory structure of the Wagner Act, this failure-of-consent justification for the ban on company unionism seems incomplete and requires substantial elaboration. Wagner and other legislative supporters of the Act repeatedly offered three alternative arguments for why the company union failed to sustain the substantive freedom or collective empowerment necessary to achieve workers' consent to managerial authority - call them the "simple coercion," "contracting into slavery," and "empowerment failure" arguments. Each of these arguments is insufficient to justify the company union ban because each of them applies equally to the non-union option which was left open to workers.

(a) The Simple Coercion Argument. - The simplest justification for the company union ban was that employers coerced workers into choosing, or participating in, company unions. Legislators - and early judicial and administrative interpreters of section $8(\mathrm{a})(2)-\mathrm{em}$ phasized employers' widespread threats and reprisals designed to intimidate workers to participate in company unions and shun outside unions. 288 Some thought that even "[i]ntimations of an employer's preference [for the company union], though subtle, may be as potent as outright threats of discharge."289 In this light, workers' inevitable

287 See 78 CONG. REC. 4230 (I934) (statement of Sen. Wagner), reprinted in I LEGISLATIVE HISTORY, supra note 38, at 24-25 (warning that a company union ban is essential to avoid either "industrial fascism" or worker "revolt, with wide-spread violence," and that a company union cannot "insure industrial peace" because "[m]en versed in the tenets of freedom" will not accept such denial of freedom). Wagner's claim here is not that the company union caused industrial unrest because employers used it to divide and conquer the workforce (although Wagner did believe that too, see 79 CoNG. REc. 7570 (1935), reprinted in 2 LegisLative HISTORY, supra note 38 , at 2334), but that the company union failed to legitimate the workplace regime for workers committed to a certain view of workplace freedom.

288 See, e.g., Hearings on S. 2926, supra note 65, at 80 (statement of Sen. Wagner), reprinted in I LEGISLATIVE HISTORY, supra note 38 , at 110 (stating that protecting individual worker choice against employer compulsion to join company unions "is all this legislation is intended to do"); 78 CONG. REC. 12,04I, 12,042 (1934) (statement of Sen. Wagner), reprinted in I LEGISLATIVE HISTORY, supra note 38, at I234 (arguing that "[r]efusal [by the worker to accept the company union] means the loss of his job," and that "[t]hat is the way a company-dominated union is organized"); id. at 12,020 , reprinted in I LEGISLATIVE HISTORY, supra note 38 , at $1 \mathrm{r} 89$ (stating that company unions are formed by "coercive methods").

${ }^{289}$ NLRB v. Link-Belt Co., 3II U.S. 584, 600 (I94I). The quote is from Justice Douglas's opinion for the Court, but it faithfully mirrors some (though not all) Congressional opinion in the debate over the Act. See, e.g., Hearings on S. 3266 Before the Senate Comm. on Interstate Commerce Amendments to the Railway Labor Act, 73d Cong., 2d Sess. 13 (1934) (statement of Joseph Eastman, Federal Coordinator of Transportation); Hearings on S. 2926, supra note 65, at 124 (statement of Sidney Hillman), reprinted in I LEGISLATIVE HiSTORY, supra note 38, at I54; S. REP. No. 573, 74th Cong., Ist Sess. ro-I I (1935), reprinted in 2 LEgisLATIVE HISTORY, supra note 38, at 23IO. But cf. SENATE COMM. ON EdUC. AND LABOR, 74TH CONG., IST SESS., Comparison OF S. 2926 AND S. 195827 (Comm. Print I935), reprinted in I Legislative 
presumption that the employer prefers the company union makes the mere availability of such entities inherently coercive.

Nonetheless, this justification for the company union ban is inadequate as a coherent interpretation of section 8(a)(2). Proponents of the ban believed that employers had equally widely conditioned workers' jobs on their "choice" of no union and that workers were as likely to presume their employer's preference for the open shop as for the company union. Yet the entire architecture of the Act was premised on allowing, not eliminating, the non-union option. Governmentsupervised, secret-ballot elections and administrative sanctions against unfair labor practices would protect against just such coercion in the collective choice process. ${ }^{290}$ If, as Wagner was convinced, that machinery was adequate to safeguard workers from direct managerial reprisals for their choice of an outside union over no union, ${ }^{291}$ why was it not adequate to safeguard the choice between a company union and either of those two options?292

HISTORY, supra note 38 , at 1352 (stating that employer has right to "suggest" labor organization, though not to dominate it); 78 CoNG. REc. 10,559, 10,560 (1934) (statement of Sen. Walsh), reprinted in I LEGISLATIVE HISTORY, supra note 38 , at II25 (stating that employer has the right to "peaceful persuasion" as to merits of organization). This accords with the early administrative viewpoint, see, e.g., In re Wheeling Steel Corp., I N.L.R.B. 699, 709 (1936) (stating that employees' initiative with respect to a company union was "determined by fear of [the corporation]"), and with leading commentary, see, e.g., Archibald Cox, Some Aspects of the Labor Management Relations Act, xg47 [Part I], 6r HaRv. L. Rev. I, 15 (1947).

290 The premise that government intervention would free workers' collective choice from managerial coercion may have been false. See Paul Weiler, Promises to Keep: Securing Workers' Rights to Self-Organization Under the NLRA, 96 HARv. L. REV. 1769, 1776-81 (1983); infra notes 488,498 . Skepticism about the possibility of uncoerced choice in the workplace becomes even more tempting once workers' interests and preferences are understood as potentially endogenous to the structure of labor-management relations. See infra pp. 1457-58, 1478-84.

In his powerful response to employers' continued (if not escalated) coercion of workers in NLRB representation elections, Professor Weiler proposes the de facto elimination of employer campaigns altogether by allowing workers to choose outside unions by means of either signed membership cards or instant elections. See Weiler, supra, at $1806-08,181 \mathrm{r}-16$. These reforms would be insufficient to prevent continuing coercion in a regime that permitted workers to elect a company union in NLRB elections. Workers who want to establish a company union may have less incentive to hide their intentions from an employer, whom they would often expect to support the company union. Or, management itself might initiate the company union campaign. This would open the door to employer coercion of other workers. The distinction between employer campaigns against outside unions and their campaigns for company unions would, then, provide grounds for eliminating the company union option altogether while allowing the non-union option - but only in a world in which, contrary to legislators' original assumption, the Board could not eliminate employer coercion.

291 "Congress rejected [the] hopeless argument" that "no law could prevent the anti-democratic practice of systematic discharge for union affiliations." Letter from Senator Wagner to the New York Times I (Apr. 25, 1937) (on file in The Wagner Papers, supra note 30, at 600 SF ro3, Folder 38); see also Robert Wagner, National Labor Relations Bill, NBC Radio Address 3 (May 21, I935) (transcript available in The Wagner Papers, supra note 30, at BB I20, Vol. 2, $\S$ iii) (arguing that "secret ballot" will force employer "to treat all [worker-voters] alike").

292 Even employers' continued requirement that workers join the company union against 
(b) The Contracting-Into-Slavery Argument. - One could infer from three alternative legislative arguments that the ban on company unions rested on workers' inalienable right to independent collective representation. Wagner often advanced the following proposition:

To say that [the management-controlled] union must be preserved in order to give employees freedom of selection is a contradiction in terms. There can be no freedom in an atmosphere of bondage. No organization can be free to represent the workers when it is the mere creature of the employer. ${ }^{293}$

Of course, there is no "contradiction in terms" in the idea of giving workers the option of voting for a labor-management structure that operates under the control of management. There is nothing intrinsic in the liberal concept of "freedom of choice" that bars choices that trade future freedoms of either the workers or their chosen labor organization for perceived benefits. ${ }^{294}$ Such choices are made every

their will would not in itself prevent them from freely voting for an outside union in a secret ballot election. For this reason, Professor Kohler's proposition - that recent circuit court decisions that allow the establishment of inside unions "return[] the law to its pre-Texas \& New Orleans Railway state" and therefore fail to "remov[e] all obstructions to the exercise of employee initiative to exercise their associational rights to organize" independent unions - requires explanation. Kohler, supra note 23 , at 545 (citing Texas \& New Orleans R.R. Co. v. Brotherhood of Ry. \& Steamship Clerks, 28I U.S. 548 (I930)). Further argument is necessary to show that the operation of the company union illegitimately prevents workers from organizing and electing an independent union in a legal universe that includes the NLRB machinery.

Indeed, workers' belief in a managerial preference for an inside union, and workers' resentment of managerial threats, might induce workers to be more, not less, favorably disposed to vote for an outside union, given the protection against reprisals that would, Wagner insisted, be afforded by the secret ballot. Professor Getman makes just this claim in the somewhat analogous context of an employer's preferential recognition of one of two rival outside unions. He suggests that workers' awareness of the employer's preference for one union is more likely to enhance than to reduce their support for the non-favored rival union. See Julius Getman, The Midwest Piping Doctrine: An Example of the Need for Reappraisal of Labor Board Dogma, 3I U. CHr. L. REv. 292, 306-07 (1964). One of the grounds for Getman's claim that workers will shun the company-favored union, however, is that '[t]he term 'company union' still has strong pejorative connotations." Id. at 307 . Because the legislative proscription of company unions accounts, in part, for those pejorative connotations, Getman's argument is not as compelling when deployed against that very proscription.

29379 CONG. REC. 2368,237 I (1935), reprinted in I LeGISLATIVE HiSTORY, supra note 38 ,

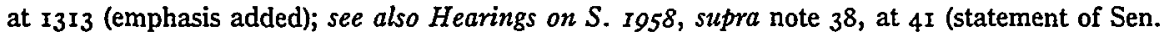
Wagner), reprinted in I LEGISLATIVE HISTORY, supra note 38, at 1417 (introducing the 1935 bill to the Senate Committee); Wagner, supra note 89 , at 9 .

294 The general point is well made in Joel Feinberg, Legal Paternalism, in Paternalism 3, I7 (Rolf Sartorius ed., 1983). Wagner did not deny that company unions provided some benefits to workers. See infra note 302. Nor did he argue that the objective costs of company unions outweighed the objective benefits, either as the grounds for a paternalistic, utilitarian justification for the company union ban, or as evidence that workers must have been coerced into "choosing" organizations with net costs. As discussed below in section IV.B.2.(c), Wagner did believe, however, that workers would develop a sense of entitlement and solidarity that could not be satisfied by company unions. 
day by workers - as by any contracting party - and are not objectionable for that reason alone, at least within the understanding of liberal legislators such as those who supported the Wagner Act. ${ }^{295}$

Second, Wagner at times linked the otherwise empty "contradiction in terms" formulation with more substantial arguments that might be taken implicitly to rest on overriding workers' group choice in the name of either inalienable rights or unratifiable conflicts of interest. ${ }^{296}$ As discussed in section III.D above, Wagner and his allies often drew an analogy between the right to participate in political democracy and the right to full representation through outside unions in industrial democracy. They also occasionally cast their rights-based defense of the company union ban in language redolent of "the Kantian argument that there is something in every human being that is not his or hers to alienate or dispose of: the 'humanity' that we are enjoined to 'respect, whether in our own person or that of another."'297

A third, frequently articulated ground for blocking workers' ratification of company unions was the inherent conflict of interest generated by managerial influence over the workers' ostensible collective agent. That conflict stemmed, in Wagner's view, from the economic dependence of both the employee representatives and the company

295 An individual worker's choice to work in a non-union workplace - or a unionized workplace, for that matter - places her, for the duration of her employment, under the coercive regime of management rules enforced by the threat of discharge. The Act did not proscribe such a choice. More to the point, the Act allowed the workforce as a group to choose nonunionization, which Wagner and other proponents understood as a state of managerial despotism. See Wagner, supra note 89 , at 8-9.

${ }^{296}$ But see p. I449 (describing Wagner's repeated denials that the Act overrode free choice).

${ }^{297}$ Feinberg, supra note 294, at 13 ; see also 79 CoNG. REC. 9668, 9685 (1935) (statement of Rep. Connery), reprinted in 2 LegisLATIVE HistoRy, supra note 38 , at 3116 (arguing that the company union ban allowed citizens to "say ' $I$ am master of my soul, I am not an industrial slave'"); 79 CONG. REC. 6183, 6r84 (1935) (statement of Sen. Wagner), reprinted in 2 LEGISLATIVE HISTORY, supra note 38 , at 2284 ("We must not now repudiate the pledge that has been given [American workers] of emancipation from economic slavery and of an opportunity to walk the streets free men in fact as well as in name."); 77 CoNG. REC. S5280 (1933) (statement of Sen. Wheeler) (stating that in company unions, workers "do not dare say their souls are their own"). The philosophical basis of Wagner's non-consequentialist justification for the company union ban need not be understood in specifically Kantian terms. One might object to the company union regime, as to slavery or serfdom, based on non-transcendental or non-universalist communitarian commitments to ways of life, see, e.g., MrchaEl Walzer, SpHeres of Justice: A Defense of PluRalism AND Equality xiv-xvi, 98-103 (1983); on an interpersonal ethic of mutual recognition and reciprocity, see Drucilla Cornell, Dialogic Reciprocity and the Critique of Employment at Will, Io CARDOzo L. REV. 1575, 1582-88 (I989); or on "anarchic sentiment" that is repulsed by a relationship that smacks of exploitation or peonage, see Duncan Kennedy, Distributive and Paternalist Motives in Contract and Tort Law, with Special Reference to Compulsory Terms and Unequal Bargaining Power, 4I MD. L. REv. 563, 624, 628 (I982). Elements of each of these positions can be found in the progressive ethos in which Wagner was immersed. 
union itself on the employer. ${ }^{298}$ The company union was thus akin to "a practice whereby the person on one side of the bargaining table pays the attorney of those with whom he deals." 299

298 See 79 CoNG. REC. 7565, 7570 (r935) (statement of Sen. Wagner), reprinted in 2 LEGISLATIVE HiSTORY, supra note 38 , at 2334. Company union representatives appearing before the Congressional committees insisted that workers could and would vote out of office those representatives who were swayed by management's tug of the purse strings. Indeed, they argued that representatives would more keenly serve the interests of the rank and file because of the bonus pay received from management, which they stood to lose if voted out of office. See, e.g., Hearings on S. 1958 , supra note 38 , at 539 (statement of Robert L. Hart, B.F. Goodrich Co.), reprinted in I-2 LEGISLATIVE HISTORY, supra note 38 , at I373, I925. Of course, the proponents of the ban had the more accurate understanding of the incentive structure facing employee representatives. True, betraying coworkers' interests risked loss of the next election and with it bonus pay, status, perquisites, power of patronage dispensation, the respect of peers, and perhaps self-respect. But challenging management risked losing all those benefits of office and, more important, loss of the job itself or of the chances of promotion that often were dangled before employee representatives.

To say the least, the incentive structure was not well-designed to align the agents' interests with those of their ostensible principals. It is true that the general nature of the workplace gave the rank and file certain advantages - spatial, communicational, and informational - in monitoring their agents that other kinds of collective principals (such as shareholders) lack. Individual workers nonetheless faced the usual free-rider disincentives to making sacrifices (including the risk of job loss) in the name of holding representatives accountable, weighed against uncertain gains from a more honest slate of company union representatives. Wagner and other legislators were also familiar with special obstacles to monitoring company unions. These included the failure to provide accurate information to the rank and file about the substance of meetings between management and employee representatives and the infrequency of, if not formal ban on, general meetings between representatives and their constituents. See, e.g., id. at 572 (statement of John D. House), reprinted in 2 LEGISLATIVE HISTORY, supra note 38 , at 1958 .

29979 CoNG. REC. 7565, 7570 (r935) (statement of Sen. Wagner), reprinted in 2 LEgisLative HISTORY, supra note 38, at 2334. The argument that company unions put management "on both sides of the table" was voiced by many of the bill's proponents, who drew analogies not only to an attorney's conflict of interest, but to a shareholder's right to select a board of directors that is independent of the employees, and to a seller's right to hire a sales agent who is not in the pay of the buyer. See, e.g., Hearings on S. 2926, supra note 65, at 38 (statement of Milton Handler), reprinted in I LEGISLATIVE HISTORY, supra note 38, at 68; Hearings on S. 1958, supra note 38 , at $87 \mathrm{I}$ (statement of Dr. William Leiserson), reprinted in 2 LEGISLATIVE HiSTORY, supra note 38 , at 2257 .

To assess properly the empirical severity of the conflict of interest in company unions, legislators should, again, have reimagined the operation of inside unions in the context of the new legal regime providing sanctions against just the kind of managerial threats through which the inside agents' conflict was created - that is, threats of job loss, loss of promotion, and organizational defunding or disbandment in retaliation for representatives' aggressive exercise of statutory rights of concerted activity, organizing, and bargaining. See supra p. 1444. Legislators should also have considered the degree of inside representatives' apprehension about managerial reprisals in the context of a regime that makes outside unionization a more easily available option and therefore a counter-threat that might provide additional deterrence against intimidation by management. But see Senate Hearings on S. 2926, supra note 65, at 656 (statement of Sen. Wagner), reprinted in 2 LEGISLATIVE HISTORY, supra note 38 , at 2052 (erroneously arguing that workers would be unable to vote out company unions in a post-NLRA regime because of pre-NLRA simple coercion of voters). 
Wagner's attachment to the legalistic principle that an agent should have but one master may seem unremarkable in light of his liberal juridical background and, more important, the contractualist theme of the new regulatory regime. ${ }^{300}$ It is nonetheless in tension with his recognition of the virtues of collaborationist workplace relations. Some relatively hardboiled current analysts ${ }^{301}$ have affirmed what Wagner acknowledged at the time: that company unions may have served not just as contracting agents but as beneficial consultative bodies, providing fora for exchanging information, settling grievances, and solving operational problems between parties locked in an ongoing ensemble of common and conflicting interests. ${ }^{302}$ Wagner's preferred model of integrative collective bargaining itself showed that the workplace was not inevitably a terrain of pure arms-length contracting through independent agents, but could also be a zone of more fluid, interdependent social relations that blurred functional roles in the interest of collaborative operations.

The primary difficulty, however, with the analogy to an unwaivable right to unconflicted collective voice - as with the asserted inalienable rights to political participation and to autonomous personhood - is that the Wagner Act allowed full alienation of the right to "democratic" collective bargaining, to freedom from industrial "slavery," and to collective voice of any kind, ${ }^{303}$ by permitting workers to

For historical evidence that inside union representatives used the counter-threat of outside affiliation as a way of strengthening their hand vis-a-vis management, see Sanford M. Jacoby, Reckoning with Company Unions: The Case of Thompson Products, 1934-1964, 43 INDus. \& LAB. REL. REV. I9, 30 (1989). Nonetheless, the transaction costs of converting from an inside to an outside union, and the costs to workers of "insuring" their inside representatives' income against managerial reprisal prevent the conflict of interest from being fully eliminated. I am indebted to my colleague Jeff Gordon for clarification of this theoretical point, which is illustrated historically by the experience of the prototypical company union instituted in 1914 by the Rockefeller-owned Colorado Fuel and Iron Company. In $19 \mathrm{7}$, the employee representatives of that company union unsuccessfully sought to secure such "insurance" from the rank and file. See Ben M. Selekman \& Mary Van Kieeck, Employes' Representation in Coal Mines 89-94 (1924).

300 See 79 CONG. Rec. 7571 (1935) (statement of Sen. Wagner), reprinted in 2 LEgisLative HISTORY, supra note 38 , at 2336 .

301 See, e.g., PIORE \& SABEL, supra note 10, at 124-28; Daniel Nelson, The Company Union Movement, rgoo-1937: A Reexamination, 56 Bus. Hist. Rev. 335, 335-39 (1982).

302 See Robert F. Wagner, Company Unions: A Vast Industrial Issue, N.Y. Times, Mar. II, 1934, § 9, at I ("The company union has improved personal relations, group welfare activities, discipline and the other matters which may be handled on a local basis."); Wagner Brief, supra note 125 , at $64-65$.

${ }^{303}$ Legislators could have understood the company union ban as the minimal paternalism of preventing workers from knowingly choosing an organization in which management's manipulation of employee representatives was too subtle and pervasive for workers to monitor $\boldsymbol{e x p o s t . ~}$ No legislator, however, owned up even to such minimal paternalism. In any event, this justification would not sit easily with the skeletal structure of the Act. The Act allowed workers 
choose no union. 304 Wagner repeatedly insisted that the company union ban was justified exclusively on the ground of preserving workers' free choice over modes of workplace governance. ${ }^{305}$ He never explicitly conceded that workers' free choice was overridden in the name of an inalienable right or nonratifiable conflict of interest.

(c) The Empowerment Failure Argument. - As discussed above, the primary objective of the Wagner Act was to achieve workers' "substantive freedom" by eliminating duress in workers' consent to managerial authority. The means to that end was the facilitation of collective action in the labor market in order to enhance workers' bargaining power.

Wagner explicitly connected the company union ban to his larger program of collective empowerment of workers in the labor market. The goal of redistributing bargaining power by means of independent labor organizations which, unlike company-dominated unions, were capable of amassing strike funds and engaging in trans-enterprise bargaining, ${ }^{306}$ was clearly the key element in Wagner's larger program. That goal nonetheless cannot provide the sole justification for section $8(a)(2) .{ }^{307}$ The Act allowed workers to choose two modes of

to choose non-dominated company unions. Although free of management funding and control, such unions were marked by the same key source of (subtly and pervasively generated) conflict of interest as dominated company unions, namely, the dependence of worker representatives on the employer for their livelihood and advancement. See Hearings on S. 2926, supra note 65, at 9 (statement of Sen. Wagner), reprinted in I LegISLATIVE HISTORY, supra note 38, at 39; 79 CoNG. REC. 2368, 237 I (1935) (statement of Sen. Wagner), reprinted in 2 LegisLative HISTORY, supra note 38 , at $\mathrm{I}_{3} \mathrm{I}_{2}-\mathrm{I}_{3}$. Hence, the Act allowed workers to waive their right not only to collective voice, but also to unconficted collective voice. In Senate debates, committee chair Senator Walsh maintained, with no explanation why the same argument would not apply to dominated company unions, that if non-dominated company unions "are not representative of the men, if they are not really engaged in honest collective bargaining, we must give the employees of this country, men and women, credit for recognizing that and overthrowing, in time, such organizations." 79 CONG. REC. 7648,7660 (1935) (statement of Sen. Walsh), reprinted in 2 LEgISLATIVE HISTORY, supra note 38 , at 2375.

304 Wagner often insisted both that the Act allowed the worker "to belong to any kind of union that he likes, or to stay out of all unions if that is his wish," Robert F. Wagner, Speech for Movietone I (Feb. 23, I935) (transcript available in The Wagner Papers, supra note 30, at 600 SF 103, Folder 32), and that the absence of a union gave employers "despotic control" of workers. Wagner, supra note 89 , at II.

${ }^{305}$ See, e.g., Hearings on S. 1958 , supra note 38 , at 417 , reprinted in 2 LegisLatrve HistoRy, supra note 38 , at $1803 ; 79$ CONG. REC. 6183,6184 (1935), reprinted in 2 LegisLATIVE HistoRy, supra note 38 , at 2284 ; Wagner, supra note 89 , at 9 .

306 See 79 CoNG. REc. 7565,7570 (1935) (statement of Sen. Wagner), reprinted in 2 LEGISLATIVE HISTORY, supra note 38, at 2321, 2333 (introducing the 1935 bill); 78 CoNG. REC. 3443 (I934), reprinted in I Legislative HistoRY, supra note 38, at I5; supra note I6.

307 In an important interpretive study of the political significance of the Wagner Act, Christopher Tomlins suggests that "leading advocates" of the bill condemned the company union for reasons of economic stabilization, and "not . . . because of the existence of employer interference [with the civil rights of their employees] per se." TomLINS, supra note 3 I, at 122 \& n.63. Tomlins acknowledges that the Act's protection of workers' choice of non-dominated company 
governance that would have the same harmful effect on labor-marketwide bargaining that Wagner attributed to company-dominated unions, namely, non-unionization and non-dominated company unionization. 308

2. The Debate Among Political Entrepreneurs Over Company Unionism and Worker Consciousness. - The puzzle over the justification for the company union ban thus reflects the tension between the two leading principles articulated by Wagner and his allies in the framing of the Act: the principle of workers' absolute free choice over modes of workplace governance, ${ }^{309}$ and the principle of the collective

unions poses difficulties for his argument that $\S 8(a)(2)$ was designed solely to block modes of workplace governance that did not implement market-wide bargaining (although he does not mention that the same difficulty is posed by the very premise of voluntary unionization itself). Tomlins suggests that those difficulties were resolved by the Act's combination of the company union ban and the "administrative designation of the dimensions of the group from which representatives would be selected by majority vote to bargain on the group's behalf." Id. at 123. But the proponents of the Act understood that its unit-determination provisions were intended to restrict the Board to defining units that did not extend beyond single employers. See NLRA, supra note 3, § 9(b), 29 U.S.C. § 159(b) (1988); 79 CoNG. REc. 9668, 9728 (1935), reprinted in 2 LEGISLATIVE HISTORX, supra note 38 , at 3093, 3220. They also understood that parties' voluntary aggregation of bargaining units would by no means inevitably widen ultimate bargaining configurations. See Casebeer, supra note 31, at 333; Wagner, supra note 89, at 1415. However large the issue of bargaining-unit definition loomed in the post-enactment politics of the Act, see TomLINs, supra note 31 , at $149-96$, it was not a significant issue that drove the drafting of the Act's key substantive provisions. See Handler Oral History, supra note 18, at 38 (explaining that "the unions were not fighting with one another in terms of the bargaining units," but rather, "[t]he fight was between company unions and outside unions"). It is important to recognize that $\S 8(\mathrm{a})(2)$ was deeply inscribed with the multiple purposes of redistribution of bargaining power and protection of rights of free collective choice and free association. See supra sections III.D and IV.B.I.(b). Otherwise, it is difficult to explain either the Act's allowing workers the options of non-unionization and non-dominated company unions, or the relentless efforts of legislators (and administrators and judges) to develop a satisfying choice-protecting justification for the company union ban, including the justifications discussed below at section IV.B.2.(c).

308 See supra notes $29 \mathrm{I}, 303-305$. No legislator advanced the argument that putting company unions on NLRB representation ballots might have "agenda effects" conflicting with the basic legislative goals of collective empowerment and free group choice. As the discussion above has stressed, workers were permitted several options that might "drain" votes from an independent union that would otherwise be able to win an electoral majority - including the non-union option, the non-dominated company union option, and rival independent unions. Legislators gave no reason - independent of the other justifications for the company union ban canvassed in this Article - that company unions' diversion of votes was less legitimate than the diversion caused by these other options.

309 By Wagner's "principle of absolute free choice," I mean free choice only over a range of governance mechanisms limited by the background regime of property, contract, and corporate law, and the background distribution of endowments, that practically ensured that hierarchical control of enterprise decisionmaking would rest with the agents of capital suppliers. See generally Louis Putterman, On Some Recent Explanations of Why Capital Hires Labor, EcoN. INQUIRY, Apr. 1984, at 171, 172-86 (examining why capital hires labor instead of the reverse). Thus, workers' range of governance options in NLRB elections did not include full workplace democracy, that is, worker election of managers or direct management by worker assemblies. 
empowerment and substantive freedom of workers. ${ }^{310}$ That tension was at least partly resolved for proponents of the company union ban by their particular understandings of the symbolic effects of law and managerial structures on the formation of workers' subjective interests and perceptions.

(a) Progressivism and the Principle of Free Choice. - Under one interpretation of the principle of free choice, the company union option should have been placed on NLRB representation election ballots alongside the options of non-unionization and outside unionization. Wagner was well aware of this interpretation, which was reflected in the law fashioned by the labor boards that administered the NIRA of I933-35 (including the Wagner-chaired NLB), ${ }^{311}$ in the policies of the

If the background regime of entitlements and endowments were such that unionization enhanced workers' bargaining power sufficiently to contract collectively for such full workplace democracy, then the NLRA regime would practically afford workers even that governance option. The craft unions of the late nineteenth century are one illustration of full worker control achieved by contract. See David Montgomery, Workers' ConTrol. IN AMERICA 9-27 (I979).

310 The two principles are in tension, but are not necessarily contradictory. Even if workers exercise their free choice not to unionize, the availability of the threat of unionization itself enhances their bargaining power. Hence, legislative protection of workers' free choice or freedom of association lowers the cost of organizing, thereby enhancing the collective bargaining power of even non-union workers by making their threat to unionize more credible. In this light, the company union ban can be cast as serving collective empowerment either directly - because the company union could not amass the strike funds or deploy the trans-enterprise strike power of an outside union - or indirectly - because company unionism enhanced the costs of, or illegitimately diminished the willingness of workers to choose and form, outside unions. The "puzzle" of the company union ban, as presented in the previous section, is that the availability of the option of forming a "weak" company union would not seem to weaken workers' bargaining power so long as the availability of the company union did not impede their free choice of (or their mere threat to choose) the more empowering outside union - or, at least, so long as the company union option did not impede that choice any more than did the availability of the nonunion option which was left open to workers.

311 Although the NRA boards ruled against coercive practices associated with company unionism and vigorously opposed the NRA's endorsement of company unions unilaterally imposed by management, the boards compromised by allowing workers to ratify company-dominated unions. See Firestone Tire \& Rubber Co., I N.L.R.B. (old) I73, I75-76 (1934) ("[O]rdinarily the choice [between independent and company unions], good or bad, is for the employees to make . . . ."); Kohler Co., I N.L.R.B. (old) 72, 72-76 (1934); B.F. Goodrich Co., I N.L.R.B. (old) 18I, 18I-84 (I934). NLB General Counsel Handler summarized the policy as a proscription of employer interference and domination of labor organizations, but only "where the employees have not clearly consented thereto." 78 CoNG. REC. 12,016, 13,030, reprinted in I LEGISLATIVE HISTORY, supra note 38 , at I177, I2 10. The old NLRB, however, left open the possibility that an employer's various modes of interfering with or dominating the company union would still be subject to challenge in the event that the company union won the election. See, e.g., Firestone, I N.L.R.B. at $\mathrm{I} 76$. But the Board was never presented with the question before its demise in June I935. In other words, it remained an open question whether the old Board was on the road to the thoroughgoing "absolute free choice" position allowing workers to ratify and the company to maintain even a dominated organization. It may instead have been headed toward some, perhaps diluted, version of the Wagner Act NLRB's position that workers would be permitted to choose a company union only if it were fully cleansed of company 
Federal Transportation Coordinator prior to the Railway Labor Act Amendments of 1934,312 and recurrently in testimony during the NLRA hearings over which Wagner presided. ${ }^{313}$ In the view of managerial and company union representatives, company unions were "obstacles" to outside unions only for the unobjectionable reason that the former provided greater worker preference-satisfaction than the latter. ${ }^{314}$

During the framing of the NLRA, not only self-interested employers and company union representatives, but also such longtime progressives as Donald Richberg, General Counsel to the NRA, and FDR himself forcefully asserted workers' right to choose company unionism. ${ }^{315}$ Both Roosevelt and Richberg cast the pro-company-union position in language that matches Wagner's own professed commitment to worker free choice. ${ }^{316}$ Wagner's view of unions as organic

domination and conflict of interest. See, e.g., NLRB v. Falk Corp., 308 U.S. 453, 46r (I940). The compromised treatment of company unions was one of the few major policies of the NRA labor boards that Senator Wagner did not bequeath to the Wagner Act Board.

312 See BuReau of LABOR Statistics, supra note 16 , at 223.

313 See Hearings on S. 2926, supra note 65 , at 53 I (statement of Ralph F. Foster), reprinted in I Legislative History, supra note 38 , at 27 ; id. at 677,715 (statement of G.L. Fullmer, AT\&T Co.), reprinted in I LEGISLATIVE HistoRY, supra note 38 , at 27 ; id. at 674,712 (statement of Francis C. Maloney, N.Y. Telephone Co.), reprinted in x LEgISLATIVE HistoRY, supra note 38 , at 27 .

314 See Hearings on S. 1958 , supra note 38 , at 4 II (statement of Jack Larkin, Wierton Steel Co.), reprinted in I-2 LEgISLATIVE HisTORY, supro note 38 , at 1373,1797 ("If the [AFL] is good for the workers of this country it can win on its merits and it ought not to have any laws designed to exterminate other organizations . . . .". "Who knows better than we, the employees, what the employees desire? Is the labor board to tell us that what we desire is not good for us? We believe that a fair election with a secret ballot conducted by the Government will best subserve our rights and our desires." Id. at 547 (statement of A.B. Trembley, Goodyear Tire \& Rubber Co.), reprinted in I-2 LegISLATIve HistoRy, supra note 38 , at 1373 , I933. These statements came, of course, from self-interested witnesses. As legislators knew, employers arranged the testimony of company union representatives and paid them for their time. See Hearings on $S$. 1958 , supra note 38 , at 773 , reprinted in 2 LEGISLATIVE HiSTORY, supra note 38 , at 2159 . Nonetheless, the extent to which company unions preempted independent unions due to "genuine" preference-satisfaction rather than to coercion or illegitimate preference-transformation is a controversial normative and historiographic issue, analyzed at length in Barenberg, cited above in note 28 .

315 From the time $\S 7$ (a) of the Recovery Act of 1933 became law, Richberg and Roosevelt repeatedly affirmed their view that the provision allowed employers to maintain company unions. See Gross, supra note 83 , at $13,33,61,67$; LoRWIN \& WUBNIG, supra note 90, at I12-13. Indeed, it was FDR's personal settlement of the automobile industry dispute in March of 1934, which permitted company unionism within a system of proportional representation, that dealt a "staggering blow" to the policies of the Wagner-chaired National Labor Board and undercut the prospects for Wagner's just-introduced Labor Disputes Bill. Id. at 113, 357; see also 78 CONG. REC. 5384, 5384-85 (1934), reprinted in I LEgislative HistoRY, supra note 38 , at $1067,1067-69$ (giving Roosevelt's statement in the settlement of the automobile industry dispute).

${ }^{316}$ See LORWIN \& WUBNIG, supre note 90, at 357 (quoting FDR supporting a system of proportional representation and company unionism "in which all groups of employees, whatever may be their choice of organization or form of representation, may participate in joint conferences with their employers"); DoNald R. RichberG, The Rainbow 55-56 (1936). 
groups unified by solidary interests and norms - and his increasing exposure to employers' use of company unionism to divide the workforce - underlay his intensified opposition to company unions, and his increasing commitment to majority rule and exclusive representation, during the NRA years. ${ }^{317}$ In contrast, FDR's acceptance of company unions and proportional representation rested on a purely associational, rather than organic, conception of unionization. ${ }^{318}$

The antipaternalist principle that the progressive proponents and opponents of company unionism each claimed as their own was, of course, deeply rooted in the liberalism from which American progressive thought sprang. ${ }^{319}$ Among progressive academic thinkers, even such a committed communitarian as Dewey insisted that genuine social cooperation could rest only on the voluntary initiative of individuals. ${ }^{320}$ Progressive "practitioners" such as Wagner consistently

317 During the NRA period, the antipaternalist arguments for allowing worker choice of company unions were closely linked with the voluntarist arguments for proportional representation. Franklin Roosevelt, the administrators of the NRA, and the employer representatives on the NRA labor boards pressed the two arguments concurrently. See TomLINs, supra note 3I, at II4-I5. Institutionally, however, there is no need to combine proportional representation with legalization of company unions. Indeed, the NRA boards' policy was to allow the company union option in majority-rule elections for exclusive representatives. Wagner's I934 Labor Disputes Bill reversed that policy: it would have banned company unions without mandating exclusive representation by the majority representative. Only the NLRA itself combined the company union ban with exclusive representation. That combination accords with Wagner's ultimate view that only autonomous unions acting as exclusive representatives could provide sufficient organic solidarity and collective empowerment to achieve genuine consent. The question, however, remains: How was that rationale consistent with Wagner's commitment to the policy of allowing workers as a group the option of no unionization and to the general principle of allowing workers as a group free choice among modes of dealing with management?

318 According to his Secretary of Labor and longtime associate, Frances Perkins, Roosevelt likely did not understand

what solidarity really means in the trade union movement. He tended to think of trade unions as voluntary associations of citizens to promote their own interests in the field of wages, hours, and working conditions. He did not altogether grasp that sense of their being a solid bloc of people united to one another by unbreakable bonds which gave them power and status to deal with their employers on equal terms.

Frances Perkins, The Roosevelt I KNew 325 (1946). Consonant with Perkins' recollection, Arthur Schlesinger, Jr. explains FDR's views on labor as an ideological holdover from pre-war progressivism, unmodified by the post-war brand of participatory labor progressivism of the likes of Wagner, Brandeis, and Frankfurter: "Reared in the somewhat paternalistic traditions of prewar progressivism and of the social work ethos, Roosevelt thought instinctively in terms of government's doing things for working people rather than of giving the unions power to win workers their own victories." SCHLESINGER, supra note 50, at 402 .

319 See KLOPPENBERG, supra note 95, at 40I-IO; WESTBROOK, supra note $16 \mathrm{I}$, at 430-39.

320 See KLOPpEnBERg, supra note 95, at 400-or; John Dewey, Interview, in I BELIEve 347-48 (Clifton Fadiman ed., 1939); cf. Alan Ryan, Communitarianism: The Good, the Bad, \& the Muddly, Dissenr, Summer 1989 , at 350 , 350-5I (denying an inevitable contradiction between communitarianism and liberalism). Although Dewey meant to rule out political or social coercion as roads to cooperation, he was not averse to political engineering of an "enabling" kind, including social reconstruction that altered the environments in which individual person- 
voiced the theme of workers' free choice and self-determination. Wagner's unwavering premise that workers would remain free not to unionize - the hallmark distinguishing a contractualist from a corporatist labor law regime ${ }^{321}$ - reflected the bedrock voluntarism of the Wagner Act, as the previous section emphasized. In fact, the leading corporatist among interwar labor progressives, Herbert Croly, was also the only prominent proponent of compulsory unionization. ${ }^{322}$

(b) Wagner's Unresolved Tension Between Individual and Group Consent. - Although Wagner remained enough of a liberal (and political pragmatist) never seriously to entertain mandatory unionism, he was also closely enough aligned with progressive corporatism to blur the line between individual and group consent, in the name of collective empowerment. That is, Wagner often spoke of workers' voluntary consent and cooperation in mass production industry as a group rather than an individual phenomenon. Company unions, unlike autonomous unions, "hampered the efforts of labor to preserve order within its own ranks or to restrain the untimely and wayward acts of irresponsible groups."323 Full collective bargaining was necessary not only to enhance workers' bargaining power and to elicit labor's sense of responsibility for the efficient operations of the common enterprise, ${ }^{324}$ but also to enable unions, in lieu of the employer or the state, to discipline those workers who refused to consent to the regimes of either workplace or social governance. So long as the new regime of cooperation through collective bargaining elicited the actual consent of a majority of workers, the problem of democratic consent in the workplace was solved. ${ }^{325}$ The expected alignment of individual preferences with group interests, if not fully achieved by the anticipated galvanizing force of legislative symbolism, ${ }^{326}$ would be com-

alities were shaped. Indeed, such reconstruction was central to his and other progressives' social visions, including Wagner's. See supra note 265 .

${ }^{321}$ See Tamara Lothian, The Political Consequences of Labor Law Regimes: The Contractualist and Corporatist Models Compared, 7 Cardozo L. REv. 1001, 1005-II (I986).

322 See Croly, The Promise of AMerican Life, supra note i65, at 386-89.

32378 CONG. REC. 4229,4230 (1934), reprinted in I LEGISLATIVE HISTORY, supra note 38 , at 24; see also id., reprinted in I LEGISLATIVE HISTORY, supra note 38 , at 25 ("[T] he company union line of organization is least likely to bring forth the restraint of irresponsible employees by others of their own group ...."); 79 CONG. REc. 2368, 2371 (1935), reprinted in 1 LEGISLATIVE HISTORY, supra note 38 , at $\mathrm{r}_{3} \mathrm{I} 2$ (stating that, without unions, employees "cannot exercise a restraining influence upon the wayward members of their own groups").

324 See supra sections III.D. and III.E.

325 "Is not this despotic control of all by the employer [in the non-union workplace] over all less desirable than a democratic process whereby the majority of the workers represent the interests of their group in dealing with their employer?" Wagner, supra note 89, at 11 . Wagner's rhetorical question sidestepped the central question in the progressivist debate over workers' choice: why should individuals or minorities not be represented by the entity of their choice in a system of proportional representation?

326 See supra section IV.A.2. 
pleted through the union's instrumental sanctions or the workgroup's informal inculcation of social norms and sentiments concordant with those interests. 327

Wagner's thinking was consistent with the ascendancy in progressive thought not just of social integrationist goals but also of "group theory" - particularly the premise of thinkers as varied as Croly, Commons, and M.P. Follett, that individuals' objective interests were fully aligned with the group interests of their natural associations. ${ }^{328}$ Wagner wrote that "[i]n modern society, the welfare of the individual is embedded in the destiny of the group." 329 Labor organizations could themselves be effective "only when workers [were] sufficiently solidified in their interests to make one agreement covering all."330

"Free choice" for Wagner was therefore an ambiguous concept, denoting both individual and group consent. The most important unresolved tension in Wagner's thought lay in his commitment to both the individual responsibility-building effects of self-expressive workplace participation, and the group discipline he thought necessary for collective empowerment and social integration.

327 To serve their disciplinary and empowering functions, unions were thus enlisted as the frontline of the corporatist machinery of "social controls" and "collective discipline." Robert F. Wagner, Wagner Challenges Critics of His Act, N.Y. Times, July 25, x937 (Magazine), at $\mathrm{I}$, 20. Although the theme that democracy required individual self-discipline was prominent in the thought of Jeffersonian progressives like Brandeis, see STRUM, supra note II8, at 192, it was extended to the notion of group self-restraint by collectivists such as Croly and Tugwell. See HABER, supra note IIg, at 97 (stating that, for Croly, "there was no loss of self-respect when subordination was self-imposed" by the group); TUGweLL, supra note I89, at 99-100 (arguing that collectivist industrial democracy would achieve "genuinely effective discipline" from within the workforce rather than from above). The exercise of the core right of "selforganization," enshrined in both the NIRA and the NLRA, would simultaneously serve as workers' self-implemented disciplinary and normalizing mechanisms in Foucault's sense. See Michel Foucault, Power/KNowledge: Selected Interviews and Other Writings, 1972-1977, at 104-06 (Colin Gordon ed. \& Colin Gordon, Leo Marshall, John Mepham \& Kate Soper trans., 1980).

328 On group theory in progressive thought, see, for example, LusTig, cited above in note I49, at I20-3I, I34; Daniel R. Ernst, Review Essay, The Critical Tradition in the Writing of American Legal History, to2 YALE L.J. Ior9, I071-73 (1993); Price, supra note 218, at 166778. Herbert Croly was perhaps the most frank proponent of the subsumption of individual interests in group interests. In the bible of progressive reform, The Promise of American Life, he wrote that the non-union worker was an "industrial derelict" who should, in the name of workers' common interests, be "rejected as emphatically, if not as ruthlessly, as the gardener rejects the weeds in his garden for the benefit of fruit- and flower-bearing plants." CroLY, supra note 165 , at 387 .

329 Wagner, supra note 163 , at 395 . He believed that "[i]t was only natural" for workers to reject company unions for independent labor organizations. 81 CONG. REC. 2943 (1937). In his Senate speech supporting the Norris-Laguardia Act, Wagner described unionization as a product both of objective "necessities" and of the human urge "to associate." 75 CONG. REC. $49 \times 6$ (1932).

330 Hearings on $S$. 1958 , supra note $33 \mathrm{r}$, at 43 (statement of Sen. Wagner), reprinted in I LEgisLATIVE HistoRy, supra note 38 , at 1373 , I4I9. 
(c) "Domination" Under Section 8(a)(2) as Structural Coercion and Hegemonic Interest-Formation. - Wagner believed that legislative policy would help guide workers' subjective preferences toward their "natural" group interest in independent unionism. 331 This empirical assumption mitigated the tension between his declarations that workers were absolutely free to choose non-unionization and his belief that the non-union workplace was a state of illegitimate despotism. But if Wagner indeed believed the majority of workers would choose outside unionism over non-unionism and company unionism, ${ }^{332}$ the need for the legal prohibition on company unionism remains a puzzle. ${ }^{333}$ Among his pronouncements are the kernels of two further justifications for the ban that could be cast - and were, by the Act's early interpreters - as a means of simultaneously protecting workers' objective interest in collective empowerment and their free choice. The justifications rest on the same endogeneity of worker interests and perceptions that contributed to Wagner's confidence that workers, at least in the mass production industries, would generally disfavor the non-union and company-union options.

(i) The Hegemonic Interest-Formation Justification. - Wagner occasionally referred to company unions as "sham[s]" or "masquerades" or "pretended union[s]."334 But protection against simple managerial misrepresentation about the empirical differences between inside and outside unions was not the driving rationale of the company union ban. The ban was carefully drafted to include grievance-adjusting shop committees "even though [the employer] does not use such shop committee[s] as a subterfuge for collective bargaining on the essential points of wages and hours." 335 Outside unions, in any event, had

3318 I CoNg. REc. 2943 (1937).

332 Handler Interview, supra note $9 \mathrm{r}$.

333 Of course, it is possible that, despite Wagner's constant assertions that the Act generally and the company union ban specifically did not compromise the principle of free group choice for workers, he was consciously or unconsciously willing to countenance either outright paternalism or choice-overriding protection of third-party interests. But see sttpra note 146. That is, he may have supported a ban on the choice of company unions because they ill-served what he took to be workers' objective interests, the public interest, or even (as in the public choice story) the private interests of organized labor. If these were Wagner's hidden motives, then presumably only political expediency would explain his willingness to allow the non-union and non-dominated company union options, which also failed to serve workers' objective interests, the public interest, and the interests of organized labor as he conceived them.

${ }^{334} 79$ CONG. REC. 6183, 6184 (1935) (statement of Sen. Wagner), reprinted in 2 LegisLative HIstoRY, supra note 38 , at 2282-84; 79 CONG. REC. 7565, 7570 (1935) (statement of Sen. Wagner), reprinted in 2 LEGISLATIVE HISTORY, supra note 38, at $2321,2334$.

335 SENATE COMM. ON Educ. AND LABOR, supra note $5 \mathrm{I}$, at $\mathrm{I}$, reprinted in 1 Legislative HistoRy, supra note 38 , at 1319 , 1320. S. 1958 altered the definition of "labor organization" to include entities that dealt with management concerning "grievances" as well as "wages, rates of pay or hours of employment." Id., reprinted in I LEGISLATIVE History, sulpra note 38 , at 1319, 1320 . 
every incentive to provide information about those differences. 336 Wagner believed that after the highly publicized, bitter fights between inside and outside unions during the NRA years, workers and the public-at-large were "overwhelmingly conscious" of the differences between the two entities. 337

Was there something more systemic and subtle about the effect of company unions on worker perceptions and preferences that disabled workers from exercising genuine choice in the service of their own interests? Wagner's recognition that legislative edicts shaped workers' subjective interests and perceptions could sit easily with a recognition of consciousness-shaping by the structures of managerial authority. If management exerted such influence through company unions, then seemingly paternalistic government intervention could be understood actually to protect worker choice against employer paternalism. Remarks in Wagner's writings and the legislative proceedings suggest such a view. Wagner endorsed Tugwell's appeal for public education to remedy the exposure of " $[t]$ he masses of people . . . to all kinds of interested pressures from those who expect to exploit them as a source of profit." "338 Wagner was also familiar with more specific claims about the "interested," consciousness-shaping "pressures" of company unions, claims widely voiced by pro-labor progressives and, indeed, by managerial proponents of company unionism as well. The Harvard labor economist and Wagner adviser, Sumner Slichter, for example, wrote in 1929 that modern personnel methods, including company unions, were "one of the most ambitious social experiments of the age, because they aim[ed], among other things, to counteract the effect of modern technique upon the mind of the worker, to prevent him from becoming class conscious and from organizing trade unions." 339 Leslie Vickers, an economist for an employer association, testified approvingly before Wagner that "management has, through these employee-

336 Furthermore, explicit managerial misrepresentation could be remedied by means short of choice elimination, such as by the sort of administrative policing of managerial communication the Act was understood to prescribe in anti-union campaigns.

337 Wagner, supra note 259, at 23; see also Interview with Senator Robert F. Wagner for American Magazine 7 (July 7, I934) (transcript available in The Wagner Papers, supra note $3 \circ$, at 600 SF ro3, Folder $3 \mathrm{I}$ ) (stating that the public was "shocked at the spectacle" of company unions); infra p. 1458 .

338 Wagner, supra note 174 , at 18 (quoting Tugwell). Wagner believed that Tugwell opposed "not genuine individualism, but the specious cry of freedom which is used in defence of exploiters who do not desire [disinterested] government interference." Id. By endorsing the distinction between disinterested (democratic) and interested (private) preference-shaping, Wagner implicitly defended the symbolic effect of labor legislation as an instance of the former. That position was, in any event, consistent with the progressives' commitment to subordinating private interests to a democratically determined public interest. See BRAND, supra note 49 , at $278-79,288-$ 89; RODGERS, supra note 254 , at 182.

${ }^{339}$ Sumner H. Slichter, The Current Labor Policies of American Industries, 43 Q.J. EcoN. 393,432 (I929). 
representation plans, fostered the thought that ultimately . . . the interests of management and labor are identical."340

(ii) The Structural Coercion and Distorted Deliberation Justifications. - However congenial such accounts of "hegemonic"341 interestformation might seem to progressives, such as Wagner, who believed that interests and preferences were socially constructed, they appeared only as a secondary justification for the company union ban in Wagner's own thought. His primary view was that, precisely because company unions were such patent shams and operated so coercively, workers would naturally see through their seductions and opt for genuine collective bargaining. ${ }^{342}$ Indeed, Wagner seemed to believe that, just as the legal engineering reinforced workers' felt entitlement to collective bargaining, the company union ban would itself have the surgical symbolic effect of de-legitimating company unions. ${ }^{343}$

A justification of the company union ban more consistent with Wagner's overall political vision, his antipaternalist principle of free group choice, and the basic structure of the Act, then, would rest on either (I) an account of how the company union was more systemically and less remediably coercive than the non-union option, or (2) an account of how the company union in other ways damaged the social preconditions for free group deliberation and choice more than did the non-union workplace. Such accounts would focus empirically on essentially the same mechanisms that Wagner identified as creating the company union's conflict of interest as a collective agent. The normative taint of such mechanisms, however, lies in their systematic coercive and distorting effect on workers' choice over modes of workplace governance rather than in their systematic deflection of worker representatives' conduct as honest agents. That is, proponents of the

${ }^{340}$ Hearings on S. 2926 , supra note 65 , at 680 (statement of Leslie Vickers), reprinted in I Legislative HistoRY, supra note 38, at 716,718 . See also id. at 143 (statement of John L. Lewis), reprinted in I LEGISLATIVE HISTORY, supra note 38 , at 169,173 (stating that company unions are "deceptive in themselves and intended to divert the energies of the workers from their own self-protection to the protection of the corporation which employs them").

341 Critical theorists define "hegemony" as the processes of perception- or interest-formation, or other modes of consciousness-shaping, that constitute or help sustain illegitimate asymmetric relations of power. See, e.g., Lears, supra note 277 , at 568-74.

342 "The men understand thoroughly the nature of the company union which has been wished upon them as a condition of employment. They know full well whose union it is and in whose interests it will work." Wagner Brief, supra note 125, at 397; see also 81 CoNG. REc. 2943 (1937) (statement of Sen. Wagner) (claiming that "[i]t was only natural that, under the lash of treatment received," workers rejected company unions for outside unions). Other legislators, including Senate committee chair Walsh, agreed. See, e.g., Hearings on S. 1958, supra note 38, at 656 (statement of Sen. Walsh), reprinted in 2 LEgislative HiSTORY, supra note 38 , at 2038 , 2042.

343 In August, I935, Wagner said that in the NLRA the company union "has been branded according to its true colors by Congress." 79 CONG. REC. I4,229 (1935) (statement of Sen. Wagner). 
company union ban believed that the phenomenon of "simple coercion" - in which managers directly threatened workers when they made governance choices - pervaded both non-union and company-union workplaces, but could be neutralized by secret ballot elections and direct administrative sanctions. But they viewed the cadre of company union representatives under managerial control as a political machine that penetrated the social infrastructure of the workforce. That penetration illegitimately distorted group deliberation and coerced worker choice more systematically than did the nonunion workplace. Such "structural coercion" or "distorted deliberation" is well captured by Section 8(a)(2)'s central term: "dominat[ion]."344

Wagner's optimism about the trajectory of worker preferences proved, in the years after I935, to be largely (but not universally) warranted. ${ }^{345}$ Mass production workers did flood into industrial unions, and the discourse of rank-and-file activists frequently echoed, with remarkable particularity, the NLRA's animating ideology of entitlements to industrial "citizenship" and to collaboration in decisionmaking about productive efficiency. ${ }^{346}$ The NLRB and the Supreme Court nonetheless faced many specific instances in which workers appeared to favor in-house unions. In those instances, the Board and the Court often sought to reconcile the company union ban and the principle of worker free choice by appealing to Wagner's secondary justification for the ban - the idea of hegemonic interest-formation. ${ }^{347}$ By the time of the Taft-Hartley hearings in I947, in fact, the Board's chief argument for continuing the ban was that workers' choice needed protection against illegitimate processes of perception- and interestformation. 348

(iii) Alternative Essentialist Views of Worker Interests. - Both Wagner's and the Board's positions rested on the assumption that workers' objective entitlement lay in collective bargaining through autonomous unions. Assuming also a natural or engineered alignment

344 NLRA, supra note $3, \S 8(a)(2)$. The instrumental and ideological dynamics of these modes of domination, in the context of old-style company unions and new-style team workplaces, are analyzed in detail, and a revised $\S 8(a)(2)$ jurisprudence is proposed, in Barenberg, cited above in note 28 .

345 In a 1937 survey of several thousand Chicago workers in diverse occupations, more than four-fifths supported strong unions for all workers. See CoHEN, supra note 26I, at 252-53.

346 An excellent case study of this relation between the NLRA's legal discourse and worker rhetoric is offered in GERSTLE, cited above in note 233, at $183-87$.

347 See, e.g., NLRB v. Pennsylvania Greyhound Lines, 303 U.S. 26r, 268-69 (I938); International Harvester Co., 2 N.L.R.B. 3 Io, 354 (I936); Wheeling Steel Corp., I N.L.R.B. 699, 7 Io (1936).

348 See Hearings on S. 55 and S.J. Res. 22 Before the Senate Comm. on Labor and Pub. Welfare, 8oth Cong., 1st Sess. rg 2 (1947) (statement of Board Chairman Paul Herzog). Recent commentary on $\S 8(\mathrm{a})(2)$ has posited an interest-distortion justification for the company union ban. See Harper, supra note 26 , at 6-9. 
of subjective preferences with objective entitlement, workers' acceptance of company unions had to be due either to systematic coercion (Wagner's primary view) or illegitimate distortion of preferences (the Board's view) by management. Such essentialist reasoning is homologous to the radical view that workers' objective interests lay in full workers' control, and that both unionism and company unionism necessarily rest on coercion or illegitimately manufactured consent. ${ }^{349} \mathrm{~A}$ similar essentialism underpinned the managerial view that workers' objective interests lay in allegiance to management and the common enterprise, whether governed through individual employment contracts or through organicist company unions. In this view, unionism was inevitably based on coercion or manufacturing of false adversarial interests by organized labor. ${ }^{350}$ (Stripped of their untenable, essentialist assumptions that workers have determinate "objective" interests, these three views about workers' likely subjective interests are not necessarily mutually exclusive. $)^{351}$ While the view of Wagner and the Board about worker interests underpinned a blanket ban on company unions, the managerial view supports a presumption that collaborative modes of workplace governance are legitimately endorsed by workers. ${ }^{352}$

349 See Alan Fox, Beyond Contract: Work, Power and Trust Relations 274-96 (1974). This is not the only radical position. Lenin, for example, believed that workers' objective interests lay in workers' control but that their subjective preferences naturally tended toward support of trade unions. See V.I. LenIN, What Is To BE Done? 63 (S.V. Utechin ed. \& S.V. Utechin \& Patricia Utechin trans., I963).

350 This view was conveyed recurrently in Senate hearings on the NLRA. See, e.g., Hearings on S. 2926, supra note 65, at 403-04 (statement of Henry S. Dennison, Employer Representative on NLB), reprinted in I LEGISLATIVE HISTORY, supra note 38, at 437-38 (fearing that company union ban will generate two "actively conflicting segments," instead of "a single organism"); id. at 1005 (statement of Walter Drew, Counsel, National Erectors' Association), reprinled in I LEGISLATIVE HISTORY, supra note 38 , at 1043 (asserting that unions impose conflicting rather than mutual interests); Hearings on $S$. 1958 , supra note 38, at 818 (statement of Brooklyn Chamber of Commerce), reprinted in 2 LEGISLATIVE HISTORY, supra note 38, at 2204 (arguing that the false premise of the Act is that labor and management are adversaries).

351 That is, it would not be surprising for workers as a group to believe that, within the existing macro-economy, they have interests in common with management in expanding the corporate pie (the managerial view) and interests adversarial to management in the distribution of corporate revenue and risks (the organized labor view), and that within conceivable alternative macro-economies - the achievement of which may be blocked by collective action dilemmas or other transition costs - they would benefit from fuller forms of workplace democracy (the radical view). See, e.g., Jon Elster \& Karl O. Moene, Introduction to Alternatrves to CAPITALISM 9 (Jon Elster \& Karl O. Moene eds., I989).

352 Such a presumption is precisely the rule adopted in recent circuit court decisions on $\S 8(\mathrm{a})(2)$; the presumption must be overcome by a showing of actual worker dissatisfaction, actual coercion, or actual manufactured desire and consent. See cases cited supra note 24. The companion Article analyzes in more detail the shifting administrative and judicial understandings of $\& 8(a)(2)$ 's concept of "domination," in light of the ideas of structural coercion, distorted deliberation, and hegemonic interest-formation introduced above. See Barenberg, supra note 28. 
Both proponents and opponents of company unionism in the I920s and I930s asserted the same objectives of enhancing labor-management cooperation and productive efficiency. Wagner and his circle envisioned an ideal workplace that combined the collective empowerment of independent unionism with the collaborative shop committees and organicist relations that, for enlightened managerial proponents of welfare capitalism, ${ }^{353}$ could stand alone as company unions. The next section examines the theoretical framework - and contemporary elaborations - of Wagner's analysis of the dynamics of workplace cooperation. Why precisely did Wagner anticipate that effective, collaborative relations would grow only within the protective shell of collective bargaining? Again, the institutional and discursive endogeneity of preferences, interests, and norms proves central to the analysis.

\section{Reciprocity, Trust, and Resentment in Workplace Cooperation}

Wagner and his advisers understood that the labor-management relationship had the structure of a "bargaining game" vulnerable to non-cooperative outcomes stemming from opportunistic behavior by either party. The crux of the problem of cooperation was whether governance mechanisms could be devised to induce labor and management to exchange credible mutual commitments - labor to provide high effort and collaboration in problem-solving, management in return to provide the fair long-term compensation and job security anticipated by workers. Stated at this generalized level, the "problem of cooperation" as understood by the framers of the Wagner Act is substantially the same as the problem addressed in the leading legaleconomic models of labor law of the last decade. Nonetheless, the details of both the problem and its solution diverge substantially in Wagner's and the leading legal economists' models.

Subsection I of this section briefly reviews the model of internal labor markets that constitutes labor-law economists' most sophisticated treatment of the problem of cooperation and their best interpretation of the Wagner Act scheme. Subsection 2 presents the points of divergence between that model and Wagner's view, and the deeper ideological commitments that account in part for that divergence. Wagner's distinctive commitments - consonant with his progressive

353 W.L. Mackenzie King - leading practitioner of company unionism, industrial relations adviser to John D. Rockefeller, Jr., and future Canadian Prime Minister - saw in company unionism "a means on the one hand of preventing labour from being exploited, and on the other, of ensuring that cordial cooperation which is likely to further industrial efficiency." Montgomery, supra note in, at 349-50 (quoting George P. West, United States CommisSION ON INDUSTRIAL RELATIONS REPORT ON THE COLORADO STRIKE 162-63 (I9I5)). 
philosophy as reconstructed in Part III - included an emphasis on the group formation of worker norms and sentiments; a normative and descriptive prioritization of the distributional contest rather than efficiency maximization; and an understanding that norms of fairness, perceived common interests, and trust between labor and management could be nurtured endogenously by institutional structures cleansed of excessive power disparities. In Wagner's thinking, as in certain counter-currents in recent sociological and economic thought, instrumental safeguards against self-interested opportunism offered a partial, but not primary, enabling condition for cooperation. To the contrary, Wagner recognized that instrumental hierarchy generated the trust-threatening ideological contests common to most structures of political authority. The Conclusion comments on the historicalempirical accuracy of Wagner's forecast of the consequences of his regulatory model. ${ }^{354}$

I. The model of internal labor markets and relational contracting. - In the leading law and economics model, the law of collective bargaining is a functional response to the operation of so-called internal labor markets. ${ }^{355}$ The internal labor market is a long-term contractual agreement, explicit or implicit, between employees and management, specifying job classifications and ladders; promotion, transfer, layoff, and recall rights, generally based substantially on seniority rules; wage, hour, and benefit terms, typically attached to the job-classification-and-seniority ladder; discipline and discharge rules and procedures; and enforcement procedures that range from internal grievance mechanisms to third-party arbitration or adjudication. 356

354 This section and the Conclusion aim to present theoretical and empirical grounds that support a broad theoretical framework - elaborated in the conceptual terms of current theories - incorporating the general elements and relations that Wagner stressed. Neither this general framework nor Wagner's more specific model of workplace cooperation can be comprehensively defended at the level of abstraction presented in these sections. The framework incorporates relations among institutional practices and managerial and worker consciousness - relations which are generally contingent on historical, highly contextual variables. See, e.g., RoBerto M. Unger, False Necessity: Anti-Necessitarian Social Theory in the Service of RADICAL DEMOCRACY I87 ( 1987 ); Gordon, supra note 8, at 85-87; infra note 481. From the standpoint of legal policy, such a broad framework's ultimate utility rests not only on its faithfulness to legislative origins, but also on its capacity to illuminate historically specific institutional and ideological dynamics in order to guide the application of $\$ 8(a)(2)$ to new forms of workplace cooperation. See Barenberg, supra note 28.

355 See Michael L. Wachter \& Randall D. Wright, The Economics of Internal Labor Markets, in The Economics of Human Resource Management 86, 104 (Daniel J.B. Mitchell \& Mahmood A. Zaidi eds., I99o); supra note 6.

356 See generally Peter B. Doeringer \& Michael J. Piore, Internal Labor Markets AND MANPOWER ANALYSIS I-2, 13-34 (I97I) (examining the origins and components of internal labor markets); RONALD G. EHRENBERG \& ROBERT S. SMITH, MODERN LABOR ECONOMICS: Theory AND Public Policy I39-40, 318-26 (I982); sources cited supra note 6. 
In the economists' model, internal labor markets serve as efficient contractual safeguards against the threat of opportunistic behavior under conditions of match-specific investments and asymmetric information between the parties. ${ }^{357}$ Both individual workers and firms are presumed to make match-specific investments, including job-specific training, learning-by-doing, and inculcation of idiosyncratic organizational and interpersonal routines. Such match-specific investments yield a joint surplus or "quasi-rent" to the parties that exceeds what they could generate by ending the relationship and turning to the external labor market for new partners. As a result of the sunk investment, the parties are locked ex post into a bilateral-monopoly bargaining game over the division of the surplus. The game is vulnerable to strategic quits or discharges that deny one party its expected return on the match-specific investment. It is also vulnerable, in bargaining over wages and employment security, to hold-ups and uncertainties stemming from informational asymmetries. Management may strategically misrepresent the state of product markets, technological innovation, and the firm's financial picture; the individual worker may misrepresent her degree of work effort or the opportunity wage she could earn in the external labor market. 358

Even independent of match-specific investment, information asymmetries generate another governance problem. The individual worker has an incentive to shirk to the extent that management has less than full information about the effort level and marginal productivity of individual workers within interdependent or costly-to-monitor work processes. Similarly, management has an incentive to raise required effort levels by misrepresenting market, technological, and financial conditions. 359

In the legal economists' model, both of these governance problems are mitigated by internal labor markets. Arrangements that effectively require workers to post a "bond" or to sink costs in match-specific investments safeguard against opportunistic quitting or shirking by individual workers. ${ }^{360}$ These safeguards take the form of deferred compensation over the worker's career-cycle: early in the workers'

357 The potential for such opportunistic behavior presents a governance problem because it directly imposes transaction costs within the relationship and indirectly discourages such potentially surplus-yielding matches. See Michael L. Wachter, Does the NLRA-System Protect Union or Firm from Rent-Seeking? 16-23 (Sept. 2, 1992) (unpublished manuscript, on file at Harvard Law School Library); Wachter \& Cohen, supra note 6, at 1358-61; Wachter \& Wright, supra note 355 , at $90-92,94$.

358 See Williamson, supra note 65, at 244; Wachter \& Cohen, supra note 6, at 1360-61; Wachter \& Wright, supra note 355 , at $94-95$.

359 See Wachter \& Wright, supra note 355 , at 96.

360 See GARY S. BECKER, HUMAN CAPITAI I8-29 (I964). See generally Michael C. Jensen \& William H. Meckling, Theory of the Firm: Managerial Behavior, Agency Costs and Ownership Structure, 3 J. FIN. EcoN. 305, 308 (I976) (explaining the concept of "bonding" by an agent). 
career wages are set below opportunity wages, while senior workers receive higher, "backloaded" wages and benefits (for example pensions and severance pay). Workers thus have an incentive to stay with the firm and perform well so as not to lose the deferred compensation that comes with progress up the seniority ladder.

Legal economists also identify safeguards against management's opportunistic lowering of wages below workers' expected share of the joint surplus, discharging of senior workers before they can reap their deferred compensation, and illegitimately intensifying work requirements. These safeguards take the form of seniority rules, downwardly rigid wage classifications, well-defined job classifications, and sunk capital. To prevent management from simply firing higher-compensated senior workers or from lowering wages on a false claim of worsening market conditions, the internal labor market requires management to adjust to adverse environmental changes by maintaining wage levels and laying off junior workers before senior workers. This rule, by forcing management to absorb a consequent decline in output and revenue and a loss of sunk capital, acts as a bond against opportunistic exploitation of locked-in workers. ${ }^{361}$ Finally, grievance systems that protect workers against unjust discharge also safeguard against opportunistic dismissal of more expensive and less productive senior workers.

These implicit or explicit contractual safeguards against opportunism are, however, only as effective as they are enforceable. Since the entire governance problem in this model is generated by the parties' presumed opportunism, what ensures that the parties can make credible commitments to honor those rules of the internal labor market that are not self-enforcing?362 Specifically, what prevents management from opportunistically lowering wages, discharging senior workers in violation of the relational contract, or intensifying the pace of work? Legal economists have identified three sources of credible commitment: third-party enforcement of a formalized contract through unionization; the possibility of reprisal and loss of future surplus owing to the repeat-play nature of the employment relationship; and reputation sustained by prudential long-term self-interest. ${ }^{363}$ According to this

361 See, e.g., Wachter, supra note 357 , at $15-17$; Wachter \& Cohen, supra note 6 , at $1378-$ 86. Professor Leslie's analysis of the internal labor market emphasizes that employees may act strategically by refusing to train new workers for fear that subsequent managerial opportunism will displace veteran workers or undermine wage standards. The internal labor market solves this difficulty by tying jobs and downwardly rigid wages to seniority. The internal labor market therefore encourages workers not only to receive but to give job-specific training. See LESLIE, supra note 6 , at $32-33$.

362 Cf. Michael Taylor, The Possibility of Cooperation 4 (1987) (arguing that, assuming self-interested behavior and the absence of coercion, "no individual has any greater incentive to abide by [an] agreement [to cooperate] than he had to restrain himself before the agreement was made.").

${ }^{363}$ See, e.g., Wachter \& Wright, supra note 355 , at $97-98$. 
model, whether unionization occurs depends on whether formal collective bargaining is more successful than repeat-play reprisals or reputational effects in maximizing the joint surplus generated by the internal labor market. ${ }^{364}$

Wagner's understanding of labor relations and law, although addressing some of the concerns about credible instrumentalist commitments, diverges in key respects from the internal labor market model.

2. Wagner's Model of the Bargaining Problem and Its Current Elaborations. - In the I920s and I930s, only a small minority of progressive managers believed that the benefits of internal labor markets outweighed their costs to the firm. ${ }^{365}$ And only a negligible number believed that formalizing the commitment to the internal labor market contract through collective bargaining was desirable. ${ }^{366}$ Many among Wagner's circle of labor reformers, on the other hand, advocated the extension of career ladders from the white collar professions to the wider labor force. Their quintessentially progressivist goal was to secure the long-term integration of a volatile working class into the political and industrial order by satisfying workers' deeply rooted and, in the reformers' eyes, justified - feelings of entitlement. ${ }^{367}$

Even with these integrationist virtues, however, rationalized personnel administration and career ladders - that is, internal labor markets - were not central to Wagner's belief that collective bargaining would solve the problem of labor-management cooperation in efficient production. Wagner and his advisers did not believe that the principal problem of the labor-management bargaining game was to ensure against shirking or strategic bargaining by individual workers or against management's strategic pre-emption of individual careercycles. Their goal was not to encourage firm-specific investments in human capital. This is unsurprising in light of the trend, then decades-old, away from idiosyncratic, skilled work in American industry. ${ }^{368}$ They did understand, in accord with recent internal labor

364 See WILLIAMSON, supra note 65 , at 272 ; LESLIE, supra note 6 , at $33-34$; Wachter, supra note 357 , at 19.

365 In 1929 , only $17 \%$ of firms ( $24 \%$ of large firms) had promotion plans, and less than $2 \%$ of large firms had pension plans. See JACOBY, supra note 19 , at 194 , 199. A mere $20 \%$ of the industrial workforce worked in companies with personnel departments, and $10-15 \%$ in companies with welfare benefit plans. See id. at 189 . Seniority systems were implemented by a minority of even large firms and provided patchy and limited job security. Job evaluation, classifications, and ladders were widely introduced only as a result of industrial union pressure after I935. See id. at $154-57,233,235-39$; SUMNER H. Slichter, JAMES J. HeAly \& E. Robert Livernash, The Impact of Collective Bargaining on MaNagement 560-6I (Ig60).

366 See supra note 65.

367 See JACOBY, supra note I9, at I23, I44-45 (noting that Cooke, Jacobstein, and Slichter - all Wagner advisers and associates - supported personnel reforms on grounds of social integration).

368 See id. at 16. 
market theorists, ${ }^{369}$ that seniority-based wages and benefits provided long-term incentives against shirking. Imposing such additional costsof-discharge on individual shirkers, however, was an insignificant incremental penalty for a workforce disciplined by the chronic unemployment of the I920s and, of course, by the labor market catastrophe of the Great Depression. In Wagner's view, the worker already faced "ruin for his family" as the price of job loss. 370

Wagner and his fellow reformers instead focused on the intertwined problems of sustaining workers' intrinsic group cooperation ${ }^{371}$ and management's commitment to norms of group fairness in decisions affecting the workforce's job security and distributive share. That is, cooperation is achieved when the workforce as a group adheres to norms and sentiments that support intrinsic motivation and creative collaboration in problem-solving. Management, in turn, rewards labor with a fair group share of the fruits of its collaborative effort and ensures that enterprise prosperity does not unfairly diminish job security for the workforce as a group.

This view of the bargaining game is concordant with the ascendancy of "group theory" in interwar progressive thought generally, ${ }^{372}$ and with the labor progressives' particular focus on the importance of workers' group "instincts"373 and "esprit de corps." 374 It also captures

369 Their views, and the economic reality of diminishing firm-specific investment, are more concordant with the analysis of the internal labor market presented by Victor Goldberg than the analysis of Wachter, Cohen, and Williamson. Compare Victor P. Goldberg, Bridges Over Contested Terrain: Exploring the Radical Account of the Employment Relationship, I J. EcoN. BEHAV. \& ORGANIZATION 249, 263-65 (rg80) (arguing that internal labor markets arise to discipline workers by raising their costs of job loss) with discussion supro pp. 1463-64 (arguing that internal labor markets arise to safeguard firm-specific investment).

370 Hearings on $S$. 2926, supra note 65 , at i 7 reprinted in I LEgISLATIVE HistoRy, supra note 38 , at 47 .

371 "Intrinsic group cooperation" denotes the workforce's commitment as a group to exert initiative and effort in ways that can neither be incorporated in contractual obligations nor enforced by enhancing the pecuniary penalties of job loss. It contrasts with the internal labor market model's emphasis on extrinsic penalties against "individual shirking," understood as individual workers' opportunistic breach of contractually specified work rules and effort levels stemming from individual workers' presumed preference for leisure over work and their capacity to free-ride on co-workers' efforts. In early writings, internal labor market theorists proposed that the long-term contractual commitment to job ladders and promotional opportunities would induce consummate cooperation by self-interested, individual workers. See OLIvER E. WILLIAMSON, MARKETS AND HIERARCHIES: ANALYSIS AND ANTITRUST IMPLICATIONS 77-78 (1975); Oliver E. Williamson, Michael Wachter \& Jeffrey E. Harris, Understanding the Employment Relation: The Analysis of Idiosyncratic Exchange, 6 BELL J. EcoN. \& MGMT. ScI. 250, 27077 (1975). Wagner and his advisers, by contrast, understood intrinsic cooperation to be a noncontractual, non-instrumental phenomenon based on an inherently group-determined mentality. See infra pp. 1475-89. For more recent empirical confirmation of the importance of both "intrinsic" and "group-based" motivation, see sources cited below in notes 375, 482-485.

372 See supra p. 1455 .

373 ORDWAY TEAD, INSTINCTS IN INDUSTRY passim (1978).

374 JACOBY, supra note 19 , at I02; see also MONTGOMERY, supra note $\mathrm{II}$, at $4 \mathrm{I} 3$ (discussing 
a nearly universal empirical finding in several research traditions within industrial sociology since the I930s - that workplace motivations and norms, as to both work effort and distribution of reward and risk, are rooted in group-generated sentiments. ${ }^{375}$ These studies confirm that work-group norms and sentiments, enforced by informal social sanctions, can either support or undermine workers' high effort/ high trust dispositions, depending on highly path-dependent, "local" institutional and ideological processes in the workplace. ${ }^{376}$

The broad picture of workplace bargaining as a game between the aggregates of "labor" and "capital" - and the game's solution through collectivization of the labor market - was framed in a r928 Wagner speech:

[C]o-operation is given only to equals. To match the huge aggregate of modern capital the wage-earner must be organized before he is reaciy to give co-operation to his employer. . . .

....

... As soon as organized labor is accepted as an integral and necessary part of our social structure, and the ill-advised efforts to destroy it are abandoned, and the struggle for mere existence terminated, labor will naturally turn to these newer tasks and to this greater vision [of concern for cooperation in productive efficiency]. Capital on the other hand admits that responsibilities and risks must have their compensation. Labor will naturally refuse to assume them unless it feels confident that it will enjoy the benefits of success. 377

Wagner and his advisers detailed a range of mechanisms through which collective bargaining was expected to secure the exchange of credible group commitments between labor and capital. Each mech-

influence on labor progressives of group psychological theories of Wagner adviser Tead, Frank Watts, and Henri de Man).

375 The finding originates in the work of the human relations school, see, e.g., FRITZ JuLES Roethlisberger \& William J. Dickson, Management aNd the WoRker 263-64 (I939), and is confirmed by the industrial pluralists, see, e.g., Stanley E. Seashore, Group CoheSIVENESS IN THE INDUSTRIAL WORK GRouP 63-69 (Arno Press I977) (1954), the sociotechnical systems school, see, e.g., Louis E. Davis \& Eric L. Trist, Improving the Quality of Work Life: Sociotechnical Case Studies, in WORK AND THE QuALITY OF LIFE 246, 249 (James O'Toole ed., 1974), industrial psychologists, see, e.g., Richard A. Guzzo \& Raymond A. Katzell, Effects of Economic Incentives on Productivity: A Psychological View, in INCENTIVEs, COOPERATION AND RISK SHARING I07, I09 (Haig R. Nalbantian ed., I987), radical sociologists, see, e.g., RICK Fantasia, Cultures of Solidarity: Consciousness, ACtIon, and Contemporary AMERICAN WORKERS 87-92 (I988), and other organizational sociologists, see, e.g., James S. Coleman, Constructed Organization: First Principles, 7 J. L. Econ. \& ORganization 7, r8Ig (Iggr).

376 See Barenberg, supra note 28.

377 Robert F. Wagner, The New Responsibilities of Organized Labor, Address at the Convention of the New York State Federation of Labor 2, 6 (August 28, 1928) (transcript available in The Wagner Papers, supra note 30, at 599 SF 102, Folder 8). 
anism corresponds to a more elaborate theory in the current economics and sociology of cooperation and trust.

(a) Third-Party Enforcement. - Internal labor market theorists consider enforceable collective bargaining agreements "the most powerful redress available to workers" to enforce their career-cycle entitlements. ${ }^{378}$ Within a purely instrumentalist theory, however, thirdparty enforcement is unlikely to sustain cooperation in either the group-exchange or the individual career-cycle models. Collective bargaining agreements typically have terms of only one to three years, but the problem of intertemporal opportunism in either model spans longer periods. 379 While judicial or arbitral enforcement of a collective bargaining agreement may prevent opportunistic reneging on compensation and job security expectations during the contract term, it of course cannot provide the same safeguard over the relevant long term of either the individual career-cycle or the multi-year cycle of group collaboration and reward. ${ }^{380}$ Each time the short-term contract expires, the parties' presumed opportunism is fully unleashed. ${ }^{381}$

(b) Self-Interested Reciprocity. - The chief instrumental mechanism for making credible commitments in Wagner's group exchange model (or the internal labor market model) is therefore the parties' threat of self-help reprisal in a bargaining game characterized by repeat plays. While the possibility of cooperation in repeated bargaining games has been a subject of much sophisticated modelling, "[i]ntuitively, the idea is simple. When the same people interact over and over again, they may choose to cooperate out of fear of retaliation, hope of reciprocation or both." 382 The general conclusion of these models is that non-cooperation is the self-interested rational response

378 Wachter \& Wright, supra note 355 , at 98 .

379 See Oliver E. Williamson, Economic Institutions: Spontaneous and Intentional Governance, 7 J. L. ECON. \& ORGANIZATION 159, I72-75 (199I) (rejecting the argument that shortterm sequential contracting is a feasible solution to opportunism where long-term contracting is not). This does not mean that the existing structure of collective bargaining cannot be rationalized by the greater gain in efficiency from frequent adjustment to environmental changes than from credible commitment to the rules of the internal labor market. The point is that the institution of third-party enforcement of collective agreements is not explicable as an instrumental solution to the problem of long-term enforcement of the internal labor market or the exchange of commitments to group effort, reward, and risk.

380 In addition, Wagner believed that the kind of consummate group effort necessary for efficient cooperation was intrinsically "noncontractible." ERIC RASMUSEN, GAMES AND INFoRMATION I4O (I989) (noting that effort may be "noncontractible" in principal-agent contracts because slacking may not be provable in court even if observable to the principal); see also infra p. 1481 .

381 This abstract problem was made painfully real for workers in the 1970s and 19805 who made short-term contractual concessions with the expectation of long-term, but not contractually formalized, recompense - an expectation that was unfulfilled. See, e.g., KMM MOODY, AN INJURX TO ALL I85-87 (1988).

382 ELSTER, supra note 63 , at 43 . 
of players in a Prisoner's Dilemma game, whether one-shot or finitely repeated. ${ }^{383}$ But in an indefinitely iterated two-person Prisoner's Dilemma, mutually self-interested strategies of conditional cooperation, such as the "tit-for-tat strategy"384 or the "grim strategy,"385 may generate an equilibrium of ongoing reciprocal cooperation. (Within pure game theory, however, there is nothing to guarantee that the parties will adopt such strategies).

Wagner and his advisers believed that collective bargaining enhanced the possibility for this type of self-interested reciprocal cooperation between labor and management. Their reasoning fits comfortably with contemporary instrumental theories of the "evolution of cooperation." Most obviously, unionization makes credible labor's

383 Non-cooperation or "defection" in the finitely repeated game results from the presumption of "backward induction": the parties know that defection is rational in the final repetition, and so it will also be rational in the penultimate round, and so on. See RASMUSEN, supra note 380 , at 88; Reinhard Selten, The Chain Store Paradox, 9 THEORY \& DECISION 127, passim (1978).

384 Under the tit-for-tat strategy, a party begins by cooperating in the first round, cooperates in later rounds so long as the other party cooperated in the previous round, and acts noncooperatively in a round only if the other player acted noncooperatively in the previous round. See Robert AXelrod, The Evolution of CoOperation 207-13 (1984); ANatol Rapoport \& Albert M. Chammah, Prisoner's Dilemma: A Study in Conflict and Cooperation 56-59 ( 1965 ); TAYLOR, supra note 362 , at $65-66$. Although the mutual tit-for-tat strategy is one possible equilibrium outcome in the infinitely repeated game, it is neither the only equilibrium nor is it a "perfect" equilibrium in game-theoretic terms. It is not "perfect" because, if both parties adopt the tit-for-tat strategy, it is not rational for one party actually to penalize the other for noncooperation in a previous round, because the result would be eternally alternating noncooperation. See RASMUSEN, supra note 380 , at r20. Nonetheless, empirical studies have shown the tit-for-tat strategy to be highly successful across environments made up of players with varying strategies. See, e.g., AXELROD, supra, at 42.

385 Under the grim strategy, a party begins by cooperating and continues to cooperate unless the other party acts noncooperatively in a round, in which case the first party acts noncooperatively forever thereafter. See RASMUSEN, supra note 380 , at 91 . Cooperation based on mutual grim strategies is a perfect equilibrium in game-theoretic terms. See Rasmusen, supra note 380 , at 9r. Nonetheless, "although eternal [unconditional] cooperation is a perfect equilibrium outcome in the infinite game under at least one strategy, so is practically anything else, including eternal finking [i.e. noncooperation]." Id. at 92. David Kreps' model of corporate governance relies on the self-enforcing nature of the grim strategy and the capitalized value of the parties' high-trust reputation that emerges from continued adherence to such a strategy over time. See David Kreps, Corporate Culture and Economic Theory, in Perspectrves on Positive PolitICAL Economy 90, ro2-03 (James E. Alt \& Kenneth A. Shepsle eds., I990). Emphasizing the weaknesses of Kreps's model, Williamson points both to the multiple equilibria of the repeatplay game and to numerous compelling reasons that the reputation mechanism is likely to be ineffective. See Williamson, supra note 379, at 167-69; see also infra note 407. Indeed, Kreps himself ultimately abandons the parsimonious assumptions of self-interested rationalism and resorts to the "evolutionary adaptation" of "corporate culture" to solve the problem of opportunism within hierarchical organizations - a move prefigured in Wagner's progressivism. Kreps, supra, at 127-29; see also Andrei Schleifer \& Lawrence H. Summers, Breach of Trust in Hostile Takeovers, in CoRPORATE TAKEOVERS 33, 40-4I (Alan J. Auerbach ed., I988) (putting aside the model of managerial commitments based on self-interested, feigned trustworthiness and developing instead a model based on socialization into genuine trustworthiness). 
threat of severe penalties for management's non-cooperation in each round of the group-collaboration/reward cycle. ${ }^{386} \mathrm{~A}$ second predicate for the success of a mutual strategy of conditional cooperation is each party's capacity to assess whether the other has in fact acted cooperatively or non-cooperatively in each round. ${ }^{387}$ On this score, Wagner and his advisers believed that unionization proved advantageous in two respects that have been elaborated by recent theorists. First, the union acts as the workers' collective monitor of managerial behavior. The union has a greater capacity than either individual workers or company union representatives to assess managerial honesty because it can draw on information about the behavior not only of the immediate employer, but of comparably situated employers as well. ${ }^{388}$ Second, as an entity with a long-term relationship with the enterprise, the union makes possible increasingly accurate inferences about firm performance and environmental constraints - also an important fea-

386 Theorists of the internal labor market recognize that non-unionized workers also have tools at their disposal, such as shirking and sabotage, for penalizing managerial noncooperation. See Wachter \& Wright, supra note 355 , at 98 . But Wagner and his advisers were convinced that more potent collective action was necessary to achieve successful reciprocal cooperation. In his attack on the yellow-dog injunction, for example, Wagner quoted his adviser Sumner Slichter:

Wage-earners cannot be expected to take a wholehearted interest in improving technique unless they have definite assurance that they will not be thrown out of work because of labor-saving methods they suggest. . . . The willingness of workers to co-operate in the improvement of technique presupposes that they will receive a certain and substantial reward for their help. A union strong enough to bargain on terms of approximate equality with the employer over the division of the gains from union-management co-operation would appear to be necessary in order to make the men feel confident that their cooperation will be adequately rewarded.

Wagner Brief, supra note I25, at 418-I9 (quoting Sumner Slichter). Wagner thus offers efficiency-enhancing grounds for giving unions the right to bargain over strategic corporate decisions that affect the job security of the workforce, confirmed by various empirical studies of the immediate post-enactment period and of more recent years, see sources cited infra notes 48:485. Those grounds weigh against the increased transaction costs and possibilities for strategic union behavior that some have attributed to such bargaining rights. Compare Wachter \& Cohen, supra note 6, at $1377-98$ (arguing against such bargaining rights unless NLRB proves that employer acted opportunistically) with Stone, Labor and Corporate Structure, supra note 8, at 86-96, 159-72 (arguing for such rights).

387 See AXELROD, supra note 384, at 126-30.

388 See, e.g., 78 CONG. REC. 3443 (1934) (statement of Sen. Wagner), reprinted in I LEGISLATIVE HISTORY, supra note 38 , at 15 (noting that without a union, the worker "has only slight knowledge of the labor market, or of general business conditions"); 78 CoNG. REC. 3678 (1934) (statement of Sen. Wagner), reprinted in I LeGisLative HISTORY, supra note 38 , at 21

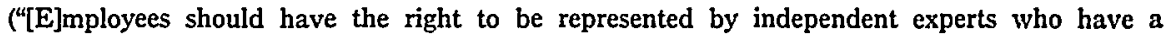
knowledge of business conditions."). Such monitoring is one of the myriad ways in which unions provide "public goods" to the work group, an efficiency-enhancing function of unionization that has received much attention from neoclassical labor economists. See, e.g., Richard B. FreEMaN ANd JAMEs L. Medoff, What Do Unions Do? 8-io (I984); Leslie, sttpra note 6, at $35-38$. 
ture of efficient relational contracting noted in recent principal-agent and game theorizing. ${ }^{389}$

The long-term continuity of the collectivized bargaining relationship also established a third enabling condition for instrumental reciprocity. Conditional cooperation strategies are more likely to prevail the longer the parties' time horizons and the lower their rates of discounting future rewards. ${ }^{390}$ Discussing this problem in the abstract context of deregulated labor-management bargaining, Jon Elster writes that "since collective wage bargaining lacks a constitution, so that one never knows who will bargain with whom in the future, selfinterest dictates a shorter time horizon," and the prognosis for selfinterested cooperation is to that extent more pessimistic. ${ }^{391}$ Recognizing the horizon problem, Wagner believed that legislation promoting the long-term stability of collective bargaining relationships would induce organized labor to collaborate more efficiently with management. 392

(c) Collective Empowerment and the Distributional Contest. - In Wagner's analysis, therefore, the crucial instrumental condition for encouraging reciprocity was the provision of new organizational weaponry, monitoring capacities, and time-horizons to labor in order to safeguard against managerial opportunism. And, as noted above, recent theorists of the internal labor market agree that unionization can be a means for management to make its commitments credible.

389 Wagner adviser Paul Douglas wrote that "[w]ith the increased knowledge of actual conditions, impossible demands upon the part of the workmen would become less frequent." Wagner Brief, supra note I25, at 402 (quoting Douglas, supra note 230, at I05). For contemporary theoretical and empirical treatments confirming Wagner's view, see, for example, MASAHIKo AOKI, The CoOperative GaMe TheORY OF THE FIRM II9-27, I52-7I (I984); Oliver Hart \& Bengt Holström, The Theory of Contracts, in ADVANCES IN ECONOMIC THEORY, FifTH WoRLD CoNGRESS 7I, 97 (Truman F. Bewley ed., I987). The union's role as collective monitor underscores the relatively weak role that "reputation" could otherwise be expected to play in making credible the parties' commitments to the internal labor market. See Williamson, supra note 379 , at $167-69$. It is precisely the employer's asymmetric access to information about product and financial markets that generates the need for the incentive-compatible rules of the internal labor market. If third-party adjudicators with subpoena and oath-enforcing powers cannot determine when an employer has acted opportunistically, it is difficult to place much weight on individual prospective employees' capacity so to judge; and it is the latter's judgment that matters. See David Charny, Nonlegal Sanctions in Commercial Relationships, I04 HaRv.

L. REv. 373 , 4r 7 n.144, 4 r8 (I990); Hart \& Holström, supra, at 142.

390 That is, a party will be less willing to exercise self-restraint against reaping opportunistic gains in the present if the jeopardized future rewards are presently less valuable. See AxELRoD, supra note 384 , at $58-59$.

391 ELSTER, supra note 65, at 172 (emphasis omitted).

392 See supra p. 1467. Of course, a precise assessment of the actual time horizon of union officers depends on a theory of intra-union politics that Wagner did not elaborate. For surveys of such theories, see, for example, KAUFMAN, cited above in note 65, at 506-13; and ELSTER, cited above in note 65 , at 169 . 
In those theorists' conceptual terms, however, unionization also poses the threat of escalated opportunism. The threat is obvious. Collective empowerment not only affords labor greater opportunities for tit-fortat penalties against managerial opportunism, but also provides workers with greater capacity to extract opportunistic increases in their share of the firm's quasi-rent ${ }^{393}$ - the very opportunism the internal labor market was supposed to check. ${ }^{394}$

Michael Wachter and George Cohen theorize that the Mackay Radio ${ }^{395}$ doctrine is the legal system's optimizing response to this problem. By allowing employers to hire permanent strike replacements at wages below those demanded by striking workers, Mackay Radio enables management to preempt unions' efforts to expropriate supra-competitive shares of the surplus from match-specific investment. The Mackay Radio "solution" for optimizing the internal labor market's safeguards against worker opportunism, however, clashes with Wagner's goal to enhance workers' capacity to inflict penalties to enforce managerial reciprocity. The Mackay Radio "solution" also points to a deeper respect in which Wagner's implicit model of the bargaining game departs substantially - both normatively and descriptively - from the legal economists'. Wagner's primary normative concern was redistribution of bargaining power as an end in itself -

393 Oliver Williamson concludes that because management recognizes unions' potential for "expropriating sunk costs in physical plant and organizational infrastructure . . . firms and industries in which investments in durable nonhuman capital are greater will be more resistant to union organization, ceteris paribus." WILliaMsON, supra note 65 , at 263 ; see also ELSTER, supra note 65 , at 167 . In this analysis, the scope of the union-enforced internal labor market as a surplus-maximizing governance structure may be extremely limited. Recall that a crucial component of the successful internal labor market is the existence of sunk capital investments sufficient to constitute the firm's primary "bond" against opportunistic cutbacks in locked-in labor. See supra pp. 1463-64.

394 Indeed, historically, managers resisted not just unionization but even the introduction of the non-unionized internal labor market for fear that the consequent uniformity in treatment of workers would spur workers' solidarity and enhance their bargaining power. See JACOBY, supra note 19 , at 95 . In other words, contrary to the prescription of internal labor market theory, management feared that the opportunism-enhancing effects of even the non-union-enforced internal labor market outweighed its opportunism-diminishing effects.

395 NLRB v. Mackay Radio \& Tel. Co., 304 U.S. 333 (1938); see George M. Cohen \& Michael Wachter, Replacing Striking Workers: The Law and Economics Approach, in PROCEEDINGS OF NEW YORK UNIVERSITY 43RD ANNUAL NATIONAL CONFERENCE ON LABOR IO9, II724 (Bruno Stein ed., r9go). Cohen's and Wachter's theory of Mackay Radio is weakened, however, by the fact that strike replacements are highly unlikely to know whether the employer is attempting opportunistically to limit wages or is fairly adjusting to unforeseen contingencies in the firm's environment. See Note, One Strike and You're Out: Creating an Efficient Permanent Replacement Doctrine, I06 HARv. L. Rev. 669, 678 n.5I (I993); supra note 389. By hypothesis, even incumbent workers lack management's financial and market information. See supra p. 1463. That is, while allowing the employer to counter workers' increased capacity for "opportunism," Mackay Radio gives the employer the capacity to escalate the very managerial opportunism against which internal labor markets were to safeguard workers - namely, opportunistic mass replacements with cheaper, less senior workers. 
as a matter of achieving what he considered social justice and genuine consent to managerial authority - wholly apart from its ancillary effect on cooperation and efficiency. ${ }^{396}$ The Mackay Radio safeguard of surplus-maximization extinguishes the very collective empowerment that was the keystone of Wagner's scheme. ${ }^{397}$ As a descriptive matter, Wagner and his institutionalist advisers concluded - as do many contemporary labor economists and sociologists - that both product and labor markets are sufficiently non-competitive to allow discretionary power and customary norms to affect institutional outcomes even

396 See supra pp. I422-26. Wagner, unlike internal labor market theorists, did not attempt to model collective bargaining exclusively as an institution "mutually agreed to" in the interests of joint surplus-maximization. WILLIAMSON, supra note 65 , at 272; see also Wachter \& Wright, supra note 355 , at 88, 105-06 (acknowledging that internal labor market theory models the distributional contest only to the extent that it constrains surplus maximization). Wachter and Wright are careful to note that, in the language of neoclassical economics, their internal labor market model examines only how alternative modes of workplace governance move the parties to or away from the "contract curve" of pareto-efficient outcomes; their model is not concerned with distributional movements along the curve. See id. Wagner and his advisers, to the contrary, pictured unionism concurrently as a weapon in the distributional struggle between labor and capital and as a governance mechanism with effects on cooperative productive efficiency. In theory, the two models may be capable of explaining the same domain of empirical phenomena because, as Dean Calabresi has recently restated, distributional contests that do not move the parties from a pareto frontier may not exist. See Guido Calabresi, The Pointlessness of Pareto: Carrying Coase Further, I00 YALE L.J. I21r, I216-I8 (1991). Nonetheless, Calabresi's point suggests that Wagner's conceptual focus on the dynamics of the distributional contest is likelier to capture more fully the complex phenomenon of labor-capital bargaining than an analysis distracted by the empty concept of pareto improvements. See id. at I215 (arguing that distributional problems should be directly conceptualized, because "[p]areto optimality is no guide and distributional issues cannot, even in theory, be avoided").

Wagner's direct descriptive focus on, and his normative prioritization of, the problem of redistributing bargaining power are reflected in the core provisions of the Act. Wagner's response to the glaring historical fact that management strategically sought to prevent workers (by means of yellow-dog contracts, blacklists, discharges, labor spies, etc.) from increasing their distributive share was not only to ban those employer tactics; his Act also gave workers the unilateral power to determine whether to collectivize the employment relationship through NLRB election and certification proceedings. But by giving workers the inalienable right unilaterally to choose unionization, the Wagner Act scheme forecloses a significant productivity-enhancing possibility in the internal labor market model. The employer is not allowed to commit contractually to pay a distributive "bribe" in exchange for workers' promise not to unionize in order to achieve a productivity-enhancing, non-unionized state. The Wagner Act proscribes such "yellow-dog contracts" that promise non-unionization. See, e.g., Medo Photo Supply Corp. v. NLRB, 32 r U.S. 678,684 (r944). "Productivity-enhancing" here refers to the engineering concept of "productive efficiency," as distinguished from the welfarist concept of "allocative efficiency" at stake in Calabresi's critique of the theory of pareto efficiency. On this distinction, see Lewis A. Kornhauser, $A$ Guide to the Perplexed Claims of Efficiency in the Law, 8 HOFSTRA L. Rev. 591, 592-97 (1980).

397 More precisely, the Mackay Radio doctrine gives workers only the limited empowerment of raising their distributive share in an amount equal to the transaction costs to the employer of hiring a replacement workforce - an amount mitigated in the internal labor market model by the savings to the employer from ridding itself of less productive and more expensive workers in the recoupment phase of their career cycles. 
at the expense of long-term surplus-maximization. ${ }^{398}$ This conclusion is contrary to the internal labor market theorists' premise that distributional contests that produce non-optional governance mechanisms are doomed in the Darwinian marketplace. ${ }^{399}$

Part of the labor-share-enhancing effect of the Wagner Act scheme is the unilateral capacity it gives workers to choose unionization at dramatically reduced costs to themselves. Workers need not offer a "bribe" of a larger distributive share to capital in order to move to a share-enhancing unionized state, whether or not surplus-maximizing. However, in the postwar era of heightened capital mobility, unforeseen by Wagner, workers' need to "bribe" capital to stay in the unionized sector came to depend on the indeterminate outcome of a decentralized "game[] of attrition," 400 absent government regulation of capital mobility. That is, if, on a market-wide basis, workers' pro-union solidarity crumbled in the face of employers' persistent flight from union to non-union status in the repeat-play game, unions would be forced to restrain their bargaining power to permit capital to maintain at least its non-union distributive share. ${ }^{401}$ Conversely, if workers' market-wide solidarity outlasted employers' anti-union resolve, workers might achieve enhanced distributive shares even if unionization was not surplus-maximizing. ${ }^{402}$

398 See Sanford M. Jacoby, The New Institutionalism: What Can It Learn from the Old?, in The Economics of Human Resource MaNagement, supra note 355, at 162, 164 (summarizing institutionalist labor economists' views). For contemporary evidence that discretionary power, custom, status comparisons, and other "sociological" factors affect labor market outcomes, see Barbara R. BERgmanN, The ECONOMIC EMERgence of Women, passim (1986); Robert M. Solow, The Labor Market as a Social Institution 5-24 (1990); William T. Dickens \& Lawrence F. Katz, Inter-Industry Wage Differences and Industry Characteristics, in UNEMPLOYMENT AND THE Structure OF LABOR MARKetS 48, 50-53 (Kevin Lang \& Jonathan S. Leonard eds., 1987); and Richard B. Freeman, Does the New Generation of Labor Economists Know More Than the Old Generation? in How LABOR MARKETS WORK 205 (Bruce E. Kaufman ed., I988); see also infra pp. I477, I481, I493-94.

${ }^{399}$ See Williamson, supra note 65, at 22-23; Wachter \& Wright, supra note 355 , at 106.

400 Robert Wilson, Reputations in Games and Markets, in GaMe-ThEORETIC MOdELs of Bargaining 27, 44 (Alvin E. Roth ed., 1985).

401 Consonant with Wagner's redistributive goals, postwar statutory interpretations prohibited employers from deliberately developing an invidious reputation for escaping a unionized workforce. In Textile Workers Union v. Darlington Mfg., 380 U.S. 263 (1965), the Supreme Court ruled that an employer may not close part of its business or relocate its entire business with the intent and likely effect of chilling unionization in future organizing campaigns against that employer. See id. at 274-75. While the theoretical rationale of the Darlington decision is thus consistent with Wagner's redistributive goal, the practical effect of that decision is sharply undercut by lower court and administrative decisions allowing partial closings and runaway shops when the employer's motive is based on substantial labor cost concerns and not on hostility to unionism per se. See, e.g., NLRB v. Adkins Transfer Co., 226 F.2d 324, 327-28 (6th Cir. 1955).

402 These alternative outcomes depend, of course, on a wide range of variables other than worker "solidarity" and employer "resolve" - including the costs of job loss to workers and capital mobility to employers, the credibility of employers' threat of escaping the reach of 
As Williamson's and Wachter's analyses suggests, the overall effect in general equilibrium may be diminished investment in capital-intensive enterprises vulnerable to expropriation by workers' unilateral unionization ${ }^{403}$ - unless, that is, unions have some means credibly to commit to non-expropriation. While management's capacity to deploy its own tit-for-tat reprisals provides one such means, Wagner also identified, as do some recent theorists, non-instrumental means of credible commitment available to both parties in the bargaining game. Indeed, in Wagner's progressivism, the non-instrumental modes of commitment were primary.

(d) Group Norms and Conventions. - Recall Wagner's insistence that the cooperationist solution - "the only solution" - to the labor problem lay in "a partnership in which moral responsibility must play a part," 404 in which norms of cooperation would be implanted in "the hearts and minds of men," 405 and in which "mutual understanding and trust" would be continuously nurtured. ${ }^{406}$ In Wagner's model, collective bargaining marked a path that led beyond self-interested instrumental rationality. This was a prescient feature, in light both of the indeterminacy and multiple equilibria in game-theoretic solutions to repeat-play bargaining games, and of the inherent weaknesses of reputation effects sustained purely by long-term self-interest. ${ }^{407}$

domestic unions altogether by moving transnationally, and the baseline degrees of union density and centralization.

403 Empirical evidence consistent with this thesis is offered in BarRy T. HIRSCH, LaBor

UNIONS AND THE ECONOMIC PERFoRMance OF FIRMS 84-89 (I99r).

404 Woolf, supra note I66, at I8 (quoting Wagner).

405 Wagner, supra note 162 , at 4.

406 Wagner, supra note 223 , at 1o.

407 See supra notes 384-385. As a general theoretical matter, "reputation effects" can be expected at most to play only a very weak role in a world premised on egoistic instrumental behavior, even allowing for the possibility of long-term self-interested action. Robert Frank argues that a theory of credible commitments based on reputations for honesty can get off the ground only by dropping the assumption of self-interested instrumental behavior. A prudent, self-interested actor can be expected to cheat only when he cannot get caught, and thus reputations for honesty could not be trusted in a purely self-interested world. See ROBERT H. Frank, Passions Within Reason: The Strategic Role of the Emotions 74-75 (I988). Frank's argument does not entirely undermine the importance of reputation in a fully selfinterested world. Even in an all-egoistic world, past cooperation by a party may be rationally taken as some evidence of some positive probability that that actor has a preference-andperceived-payoff structure with sufficiently low discount rate and sufficiently high future payoffs to warrant self-interested longer-term cooperation. Past cooperation may also be rationally taken as some evidence that an actor anticipates and fears that the second party will retaliate for noncooperation, and that the first actor wishes to avoid such retaliation. Nonetheless, in an allegoist world, past cooperation always may represent merely a short-term strategy of false reputation-building which the first actor intends to "milk" in subsequent rounds. See Carl Shapiro, Consumer Information, Product Quality, and Seller Reputation, I3 BELL J. Econ. 20, 29 (I982). In addition, common knowledge of the temptation for "forgiveness" by the second party in order to avoid a permanent cycle of non-cooperation further clouds the reputationbuilding significance of the first party's past cooperative behavior. See RASMUSEN, supra note 
Harvey Leibenstein's and Jon Elster's theories of cooperation invoke sociological concepts that recapture important aspects of Wagner's "solution" to the two-group bargaining game. ${ }^{408}$ For Leibenstein and Elster, workers as a group find it difficult credibly to commit not only to high work effort and collaborative problem-solving, but also to restraint of wage demands both in the short term (to allow greater firm investment and therefore greater surplus to share in the future)

380, at 94 (arguing that "tit-for-tat" penalties lack credibility for this reason); see also Williamson, supra note 379, at 168 (suggesting other factors that cloud reputation-building).

Reputation effects become even weaker once we add to the premise of pure egoism the two other assumptions of internal labor market theory - informational asymmetries and unforeseeable contingencies. If each party has difficulty knowing whether the other has acted cooperatively from round to round, or even knowing what would constitute cooperative behavior in novel circumstances, then past or present behavior becomes such a weak basis for mutual expectations of future cooperative behavior that preemptive noncooperation is nearly inevitable. See Bernard Williams, Formal Structures and Social Reality, in TruST: MAKING AND BREAKing CoOperative Relations 3, II (Diego Gambetta ed., I988) (noting that actors face constant temptation to take preemptive noncooperative action when all parties know that self-interested cooperation is sensitive to expectations that non-cooperation will be difficult to detect). Williams concludes that "[e]goistic micro-motivation by itself will not do" as an explanation for cooperation. Id. at II.

If the concept of "reputation effects" refers to expectations and beliefs about parties' norms of honesty, altruism, or other dispositions to trustworthiness, then we have moved beyond the premise of pure instrumental self-interest into a world of thicker culture and psychology, for which "reputation effects" is generally a mere marker. The inquiry into the phenomena of cultural norms and psychological dispositions is therefore treated below as an explicit step beyond pure self-interested rationalist methodology. The leading economic models that rely on reputation effects to explain cooperation either take the existence of a pool of cooperative or trustworthy actors as an exogenous datum, or implicitly or explicitly set aside thorough investigation of how beliefs and expectations about each party's trustworthiness are formed. See, e.g., Douglas W. Diamond, Reputation Acquisition in Debt Markets, $97 \mathrm{~J}$. Poz. EcoN. 828, 831-33 (1989) (assuming exogenous pool of cooperators); Benjamin Klein \& Keith B. Leffler, The Role of Market Forces in Assuring Contractual Performance, 89 J. PoL. Econ. 6r5, 630-3I (198I) (leaving unexplained how sellers who invest in unproductive advertising develop reputations among buyers for selling high quality goods, even though buyers know that each seller who once offers low quality goods stands to lose the same future income stream regardless whether that seller sunk costs in advertising); Kreps, supra note 385, at II3 (assuming prior reputation for trustworthiness and prior expectations among repeat players about how they will react to reputation-breaching behavior). Gilson and Mnookin conclude that cooperation within law firms rests in part on culture-driven behavior unexplained by theories that rest exclusively on actors' "rational maximization of tangible rewards." Ronald Gilson \& Robert Mnookin, Sharing Among the Human Capitalists: An Economic Inquiry into the Corporate Law Firm and How Partners Split Profits, 37 STAN. L. REv. 313, 376 (1985).

408 Leibenstein depicts the labor-management relation as a "latent," "two-sided," "adversarial relation[" at constant risk of degeneration into a pareto-inferior equilibrium, HARVEY LEIBENSTEIN, INSIDE THE FIRM: The INEFFICIENCIES OF HIERARCHY 57, 59 (1987), in which the workforce as a group minimizes effort, while management affords correspondingly minimal wages and working conditions. See id. at 48-57; Harvey Leibenstein \& Klaus Weiermair, $X$-Efficiency, Managerial Discretion, and the Nature of Employment-Relations: A Game-Theoretical Approach, in MANAGEMENT UNDER DIFFERING LABOUR MARKET AND EMPLOYMENT SystemS 79, 8I-84 (Günther Dlugos, Wolfgang Dorow \& Klaus Weirmair eds., I988). 
and in the long term (to allow more capital-intensive investment by management free of fear of future expropriation by unrestrained labor bargaining power). Management faces the challenge of credibly committing to future job security (including seniority protection to enhance productivity by reducing turnover) and enlarged distributive pay-back to workers. 409

Although Elster is pessimistic about the capacity of the parties so to commit, ${ }^{410}$ his and Leibenstein's potential solutions, like Wagner's, include "social norms" and "conventions" of cooperation. Conventions and social norms are shared standards that focus and coordinate expectations. ${ }^{411}$ Social norms, for Elster, are sustained by the approval and disapproval of others and by one's internalized feelings of embarrassment, anxiety, guilt, and shame at the contemplation of violating them. And, in a crucial theoretical break with self-interested rationalism, social norms dictate behavior in non-outcome-dependent ways. ${ }^{412}$ Empirical studies ${ }^{413}$ confirm Elster's proposition that "[t]he work place is a hotbed of norm-guided action." 414 Workplace social norms of "equality, equity, and fair division" are pervasively deployed in the process of collective bargaining. ${ }^{415}$

409 See ELSTER, supra note 65, at 74-96, 146, 276-78.

410 See id. at $276-77$.

411 Leibenstein defines "effort conventions" as standards "with a high regularity of behavior and a high degree of expectation that others will adhere to [the standards]." Leibenstein \& Weiermair, supra note $37 \mathrm{I}$, at 88 . Such conventions are contingent on the local history and culture of the firm and on socialization outside the firm, and are susceptible to concerted "leaps of imagination" and "cultural change" in the direction of pareto-superior cooperation. LEIBENSTEIN, supra note 408 , at 58-59.

412 See Jon Elster, Social Norms and Economic Theory, 3 J. Econ. PERSP. 99, 99-100 (1989). Norms that affect a broad range of social contexts (in and out of the workplace) include "everyday Kantianism" - which dictates cooperation if it would be better for all if all cooperated - and "the norm of fairness" - which dictates cooperation if most other people actually cooperate. ELSTER, supra note 65, at 123. For empirical evidence that norms of fairness may affect a broad range of economic outcomes, including employment transactions, see Daniel Kahneman, Jack L. Knetsch \& Richard $\mathrm{H}$. Thaler, Faimess and the Assumptions of Economics, in Rational Choice: The Contrast Between Economics and Psychology ior, in (Robin M. Hogarth \& Melvin W. Reder eds., I986).

413 See Frank, supra note 407 , at $x 77-84$; Solow, supra note 398 , at 5-24; sources cited supra note 398 .

414 ELSTER, supra note 65 , at $12 \mathrm{I}$.

$415 \mathrm{Id}$. at 215 . Examples of the most prevalent norms include "the norm of maintaining the reference wage," "the norm that both labour and capital should benefit from any gains in the firm's earnings," "the norm that gains from luck (e.g., improved market conditions) should be shared between capital and labour," and "the norm that gains due to increased skills should accrue mainly to the skill holder, be it labour or management." Id. at 22I. Elster powerfully attacks attempts to explain the origins of social norms in purely functionalist terms - that is, the view that social norms necessarily evolve to serve either group or individual self-interest. See id. at 124, 139, 244. Even theorists who offer a group-functionalist account of social norms recognize that, in situations of asymmetric power, social norms may develop to serve the distributive interests of the powerful rather than the pareto-improving interests of all parties. 
Wagner and his advisers did not elaborate the norms of fairness that they believed would encourage cooperation in labor-management bargaining; but they expressed optimism that collective bargaining would in fact breed cooperative norms. William Leiserson, for example, wrote that unionism - particularly in the collaborative forms represented by the Baltimore \& Ohio and Clothing Workers experiments - brought about a "great revolution in mental attitude" that "promise[d] . . . for the first time to give us an ethics of labor relations."416 He believed that labor arbitration, collaborative shop committees, and face-to-face negotiations were the institutional vehicles for developing a common set of norms and conventions for labor relations. ${ }^{417}$ But the optimism of Wagner and his advisers about the cooperationist effects of collective bargaining rested not simply on their faith in the ad hoc introduction of discrete norms or conventions. They also believed that collective bargaining would transform interests and perceptions and undergird dispositions of trust favorable to intergroup cooperation.

(e) Trust, Resentment, and Endogenous Interests. - Wagner and his advisers frequently declared that collective bargaining would promote cooperation by producing "trust" and "banish[ing] suspicion" between labor and management. 418 In the context of their pragmatic progressivism, this was not mere rhetoric but, to the contrary, was central to their understanding of social action.419 Recent theories of trust help clarify the important place of that concept in Wagner's vision of industrial relations.

Current theories conceptualize trust in two ways, each of which resonates with aspects of Wagner's analysis. First, trust can be understood as a kind of code of honor. The content of the code could be a generalized norm or duty of honesty that lends credence to specific commitments that would not be sustained by either immediate or longterm self-interest. Or, its content could be an even more generalized norm or duty to act fairly to protect the interests of vulnerable parties in unspecifiable future contingencies. ${ }^{420}$ With either content, the code

See Robert L. Ellickson, ORDER Without LaW: How Neighbors Settre Disputes i79 \& nn. 42-43 (I $99 \mathrm{r}$ ). Such "distortion" of norms (and of other subjective elements, such as perceptions, preferences, and interests) under conditions of asymmetric power is captured in the "hegemonic consciousness" rationale for the statutory ban on company unions. See supra pp.

I $457-58$.

416 Leiserson, supra note 208 , at I6r.

417 See id. at 16I-63; see also Hearings on S. 1958 , supra note 38 , at I (statement of H.A. Millis), reprinted in I LEGISLATIVE HISTORY, supra note 38 , at 1559 (stating that collective bargaining generates "a cooperative relationship, with rough ideas of fairness").

418 Wagner, supre note 223 , at ro; Wagner, Talk on Labor Relations, supra note 208, at 3.

419 See supra pp. 1414, I419-22.

420 See, e.g., NikLas LuhmanN, TRUSt aNd Power 24-3I (1979), supra note 65, at 116 I8, 274-75; ROBERTO M. UNGER, PASSION 126 (1984). Barber thus likens trust to a fiduciary 
may dictate behavior that cuts against a party's own welfare or preferences. ${ }^{421}$ Second, trust can be conceptualized as a sentiment, such as sympathy, love, friendship, or some more limited form of caring or understanding. 422 In this conception, trustworthy behavior serves rather than overrides the interests or utility of the actor, whose subjective welfare function incorporates the interests of others. ${ }^{423}$ These two conceptualizations of trust - which echo, respectively, the moralistic and the communitarian dimensions of American progressivism - are mingled in Wagner's and his associates' appeals for cooperationenhancing trust in the workplace. ${ }^{424}$

obligation "to demonstrate a special concern for other's interests above [the actor's] own" that "goes beyond technically competent performance" of specified roles subject to monitoring. BERNARD BARBER, The LOGIC AND Limits OF TRUST I4, 15 (1983). Note the similarity between concepts of trust and the contractual obligations sometimes assumed by parties to relational contracts either to use "best efforts" or to exercise fiduciary care in contingent situations. See Charles J. Goetz \& Robert E. Scott, Principles of Relational Contracts, 67 VA. L. REv. Io89, IIII-II30 (I98I). In labor law, there are no such legally imposed obligations at times when collective agreements have lapsed; thus the role of conditional cooperation, norms, and trust in labor relations is potentially significant. Although $\S \S 8(\mathrm{a})(5), 8(\mathrm{~b})(3)$, and $8(\mathrm{~d})$ of the NLRA require that the parties bargain in "good faith" when contracts expire, the requirement is virtually toothless because management need not make concessions and may unilaterally implement changes in terms and conditions of employment after negotiating to an impasse. See NLRB v. Kat2, 369 U.S. 736,745 n.12 (1962).

421 Amartya Sen refers to such codes as "commitments," Amartya Sen, Rational Fools: A Critique of the Behavioural Foundations of Economic Theory, in ScIENTIFIC MODELS AND MEN, I, 8-II, (Henry Harris ed., I979); Jon Elster labels them "codes of honor," ELSTER, supra note 65, at Ix6-r8, 274-75; Christopher Jencks calls such behavior "moralistic unselfishness," Christopher Jencks, Varieties of Altruism, in Beyond SELF-INTEREST 53, 54 (Jane J. Mansbridge ed., I990). See also BARBER, supra note 420 , at 9 (defining trust as the "expectation that partners in interaction will carry out ... their duties in certain situations to place others' interests before their own").

422 See, e.g., FRANK, supra note 407, at 51-56, 185-21I (positing love and friendship as basis for trust); Edward H. Lorenz, Neither Friends nor Strangers: Informal Networks of Subcontracting in French Industry, in TRUST: MAKING AND BREAKING COOPERATIVE ReLATIONS I94, 208 (Diego Gambetta ed., I 198) (arguing that trust is necessary for ongoing economic relations, but can be based on concerted personal contact and understanding short of friendship); infra note 458 .

423 This form of trust has been labeled "sympathy" by Sen, cited above in note 421 , at 8 ; "altruism" by ELSTER, cited above in note 65, at 36, 4r, 279-80; and "empathic unselfishness" by Jencks, cited above in note $42 \mathrm{I}$, at 54 . Roberto Unger acutely captures the difficulty of distinguishing self-interest from trustworthy altruism, once we acknowledge that a person's "interests" cannot be defined in essentialist terms:

The selfish act is cloaked more often than not in a half-transparent garb of justification.

Those who appeal to these self-serving apologies do not themselves know how seriously to take them .... The obscurity of the distinction between selfishness and altruism in human conduct is thus directly traceable to the dependence of interests upon opinions ....

UNGER, supra note 420 , at 130 .

424 Thus, Wagner frequently envisioned cooperative labor-management behavior as embodying "moral responsibility." Woolf, supra note 195 , at 6 . He wrote admiringly of what he saw 
The advantages of such non-instrumental trustworthiness for sustaining cooperative behavior in bargaining games are underscored in a host of contemporary theoretical and empirical studies. 425 The idea is straightforward: such "irrational," non-self-interested dispositions may make commitments credible where dispositions to self-interested instrumentalism would not. ${ }^{426}$ The paradox is that "persons directly motivated to pursue [even long-term, prudential] self-interest are often for that very reason doomed to fail."427 Unlike persons who are intrinsically motivated by sentiments of sympathy or moral commitment, "[self-interested persons] cannot make themselves attractive for ventures that require trust," ventures that would actually serve longterm self-interest. 428 For Wagner, cooperative labor-management relations intrinsically required a form of "social exchange" - marked by communitarian bonds, diffuse obligations, and trust - rather than "economic exchange" - marked by self-interested rationalism, con-

as the entrenched codes of cooperative managerial behavior in British culture, which he hoped could be mimicked in the United States through legislative engineering. Wagner, sutpra note 89, at I9. Alongside such paeans to moralistic unselfishness, Wagner often wrote of his expectation that collective bargaining would encourage sentiments that generate a convergence of the subjective interests of management and labor. See supra p. 1428 .

425 See infra pp. 148I-88. Among contemporary institutionalist legal economists, Goldberg, Gilson, and Mnookin have most pointedly acknowledged the importance of trust and preferencealteration in the dynamics of economic institutions, including employment relations. See Goldberg, supra note 369 , at 264 n. 33, 27I-72; Gilson \& Mnookin, supra note 407, at 334-39. Jeff Gordon interprets the Delaware Supreme Court's important decision in Paramount Communications, Inc. v. Time, Inc., 57 I A.2d I140 (Del. r989), which gave great deference to management's business judgment in rejecting a hostile takeover bid, as a possible judicial effort to sustain the kind of "community of interest between a firm and its workers" and "such values as loyalty and fairness" on which "the success of a market-oriented system ultimately depends." Jeffrey N. Gordon, Corporations, Markets, and Courts, 91 CoLuM. L. REV. I93I, I986 (1991).

426 See Jon Elster, Selfishness and Altrism, in BEYOND SELF-INTEREST, supra note $42 \mathrm{I}$, at 44,49 (stating that "being honest when it does not pay to do so is a form of irrationality," but "[i]f people pursue their selfish ends subject to the constraint of not telling lies or breaking promises, more cooperation can be achieved than if lies are made and promises broken whenever it seems expedient').

427 FRANK, supra note 407 , at 258.

$428 \mathrm{Id}$. at 255 . Kenneth Arrow notes, "Virtually every commercial transaction has within itself an element of trust, certainly any transaction conducted over a period of time. It can be plausibly argued that much of the economic backwardness in the world can be explained by the lack of mutual confidence . . . ." Kenneth J. Arrow, Gifts and Exchanges, in Altruism, MoRality, AND ECONOMiC THEORY 13, 24 (Edmund S. Phelps ed., 1975). Another economist, Fred Hirsch, writes, "The point is that conventional, mutual standards of honesty and trust are public goods that are necessary inputs for much of economic output." FRED HIRSCH, SOCIAL LIMITS TO GROWTH I4I (I976). 
tractual specificity, and instrumental enforcement. 429 "No one can contract to cooperate," he believed..$^{430}$

For Wagner, the institution of collective bargaining was well-suited to encourage the forms of trust discussed above, for reasons that are plausible in light of current elaborations on the theory of trust. Wagner emphasized two trust-building features of collective bargaining: communication and empowerment. He referred to collective bargaining as "the method of conference," in which labor and management could interact "based upon reason rather than upon force" and thereby "banish suspicion and hatred."431 His premise that ongoing communication in a common enterprise could nurture other-regarding sentiments advantageous to cooperation is supported by numerous recent psychological experiments. ${ }^{432}$ The conclusions of those experiments,

429 For sociological treatments of social and economic exchange, see, for example, PETER $M$. Blau, Exchange and Power in Social Life 88-II5 (I964); and Amitai Etzioni, The Moral DIMENSION: TOWARD A NEW ECONOMICS $67-87$ (1988). For applications and elaborations in legal scholarship, see Roberto M. UNGER, The Critical LEgal Studies Movement 57-88 (1983); Charny, supra note 389, at 391-426; Ian R. Macneil, The Many Futures of Contracts, 47 S. CAL. L. REv. 69I, 720-25 (1974).

430 Wagner Brief, supra note 125 , at 398.

43179 Cong. REC. 7573 (1935), reprinted in 2 Legislatrve History, supra note 38 , at 2341 .

432 Robyn Dawes and his collaborators, for example, ran a series of increasingly refined experiments in which groups of strangers were presented with one-shot payoffs with the structure of a Prisoner's Dilemma. See Robyn M. Dawes, Alphons J.C. van de Kragt \& John M. Orbell, Cooperation for the Benefit of Us - Not Me, or My Conscience, in BEYOND SELF-INTEREST, supra note 421 , at 97 , IOI-IIo. That is, the payoffs were such that it was always in the individual's self-interest not to cooperate, even though each received a lower payoff if all chose non-cooperation than if all cooperated. The members of different groups were permitted varying degrees of communication among themselves before each made his or her choice to "cooperate" and risk a sucker's payoff, or to "defect" and be assured of a higher payoff. Individuals' choices to cooperate or not to cooperate were kept strictly secret from the other subjects, so any breach of promise to cooperate by an individual could not be sanctioned by other subjects in any way. The percentage of cooperative choices rose dramatically with the degree of communication, both communication in which promises to cooperate were not allowed and in which promises, although completely unenforceable, were allowed. See Robyn M. Dawes, Jeanne McTavish \& Harriet Shaklee, Behavior, Communication, and Assumptions About Other People's Behavior in a Commons Dilemma Situation, 35 J. Personality \& Soc. Psychol. 1, 6 (1977). In variations on the experiment, communication enhanced the rate of cooperative outcomes only when payoffs were structured so that an individual's choice to cooperate might benefit other members of the group with whom the individual communicated, not when a choice to cooperate might benefit members of groups with whom the individual had not communicated. See John M. Orbell, Alphons J.C. van de Kragt \& Robyn M. Dawes, Explaining Discussion-Induced Cooperation, 54 J. Personality \& Soc. Psychol. 8II, 8I5 (r988). The studies concluded that communication enhances sentiments of group caring or group identity, and thereby increases cooperation over levels explained by self-interested rationalism. From a third series of experiments, Dawes and his collaborators concluded that variations in cooperation could be explained by such group sentiments rather than simply by individuals' pangs of pre-socialized "conscience" over promisebreaking, because there was no correlation between the number of promisors and number of cooperators, except in the extreme case of universal promising. See id. at 817-18. 
and of many ethnographic and quantitative studies of actual workplaces, ${ }^{433}$ mesh well with the labor progressives' premise that workers' group "instincts," 434 "irrepressible sense of 'common purpose,"'435 and "esprit de corps" 436 were vital to effective labor-management collaboration and would be encouraged by the "conference" method.437

It is true that the recent experimental studies involve individuals in relations relatively free of power disparities. Wagner and his associates believed that "the conference method" would build the sentiments and codes that constitute trust only when the collective empowerment of labor had mitigated the asymmetric power of the employment relation. Of course, the idea that severe power disparity generates distrust is old and often explored. ${ }^{438}$ But Wagner and his advisers identified at least three particular mechanisms by which empowerment encouraged workplace trust, again prefiguring some recent theoretical and empirical confirmation of the institutional endogeneity of trust.

First, following Brandeis, Wagner and his advisers believed that organizational empowerment, by enhancing labor's actual influence on workplace outcomes, gave "employees the feeling that they have a

433 A variety of clinical studies are summarized in Frank, cited above in note 407, at 22326; and Diego Good, Individuals, Interpersonal Relations, and Trust, in TruST: MAKING AND BREAKING CoOperative RELATIONS 31, 36, 44-45 (Diego Gambetta ed., 1988). On the enhancement of worker commitment by increased labor-management communication, see sources cited below in notes 482 and 483 .

434 TEAD, supra note 373 , passim.

435 MONTGOMERY, supra note II, at $4 \mathrm{I} 3$ (quoting industrial psychologist Frank Watts).

$436 \mathrm{JACOBY}$, supra note 19 , at IO2.

43779 Cong. REC. 7573 (I935), reprinted in 2 Legislative HistoRy, supra note 38 , at $234 \mathrm{I}$.

438 See, e.g., Friedrich Nietzsche, ON the Genealogy of Morals, at 36-39 (Walter Kaufmann ed. \& Walter Kaufmann \& R.J. Hollingsdale trans., Random House 1967) (1887) (analyzing ressentiment in the master-slave relationship); JAMES C. ScotT, Domination AND THE ARTS OF RESISTANCE: Hidden TRANSCRIPTS 8-23 (1990) (exploring "hidden transcripts" of disguised ideological insubordination almost universally found among subordinate groups). Roberto Unger has emphasized that power disparity can erode trust even if the subordinate group believes the power disparity is justified:

There comes a point when [even] the [justified] suppression of reciprocity begins drastically to poison the experiences of personality and community. People who stand in a relationship of inalterable superiority and subordination can hardly deal with each other as joint participants in community. Their affection for each other across hierarchical lines will be marred by condescension or pity on the part of the superior and self-abasement or shameful yearning on the part of the underling.

UNGER, supra note 420 , at 132 .

The inherent ambiguity of the experience of trust within relations of asymmetric power only compounds this erosion of affection. "[W]herever there is established, emergent, or even possible power, and whatever forms this power may take, trust and distrust become ambiguous. Each demonstration of trust may be a self-deceptive surrender; each gesture of distrust, a sign of enlightenment and emancipation." Id. at 126 . 
stake in the business." 439 Organized workers would feel like enterprise citizens and "partners] shouldering . . . the responsibilities of management."440 Second, for Wagner, the actual exercise of managerial power not checked by workers' collective power and monitoring was inevitably rife with manipulative or arbitrary practices that induced worker resentment and withdrawal of trust. Wagner's concern can be recast as a critique of transaction-cost models that see workplace hierarchy as the remedy for worker opportunism but neglect the full range of enhanced opportunities for employer opportunism created by that very hierarchy. ${ }^{441}$ Wagner went beyond even this broader instrumental analysis in his concern with the effects of such managerial discretion on psychological dispositions of trust. That is, he recognized that hierarchical rules, such as those of the internal labor market

${ }^{439}$ Hearings on $S$. 2926, supra note 65 , at 287 (statement of Arthur E. Suffern), reprinted in I LEGislative HisTORY, supra note 38 , at 316 .

44075 CoNG. REC. 4918 (1932) (statement of Sen. Wagner).

441

[T]ransaction cost theorists tend to see authority primarily as a remedy for opportunism, rather than as a device which might be abused in an opportunistic fashion. Little attention is given to the prospect that agents holding positions of authority might use the data obtained through internal audits to gain strategic advantages over lower level parties, use fiat to settle disputes in ways which suit themselves, or impose self-serving incentive systems. . . .

...

... [A]uthority relations generate the structural preconditions under which employer opportunism is most likely to be encouraged; namely information impactedness, small numbers, and availability of a tool (decision by fiat) which is tailor-made for unilateral pursuit of self-interest.

Gregory K. Dow, The Function of Authority in Transaction Cost Economics, 8 J. EcoN. BEHAV. \& ORG. 13, 20-21 (1987).

This critique is not fully applicable to the internal labor market theories set out above, which are centrally concerned with at least those forms of employer opportunism that threaten matchspecific surplus-maximization. Nonetheless, the critique identifies in workplace hierarchies the structurally potent enhancement of generalized opportunities for managerial opportunism or arbitrariness that may harm workers' (and broader organizational) interests even independent of the dynamics of match-specific investment. Milgrom and Roberts identify three types of inefficiencies generated by centralized organizational authority: the arbitrary or self-interested action of managers, the "influence costs" expended by subordinates attempting to shape managerial discretion, and the diversion of organizational resources to safeguard against the first two. See Paul Milgrom \& John Roberts, Bargaining Costs, Infiuence Costs, and the Organization of Economic Activity, in Perspectives on Positive Political Economy 57, 79 (James E. Alt \& Kenneth A. Shepsle eds., I990); Paul Milgrom \& John Roberts, An Economic Approach to Influence Activities in Organizations, 94 AM. J. Soc. (Supp.) Sr54, Sr54-Si58 (I988). Milgrom and Roberts focus on the wasteful influence activities of individual subordinates seeking job promotions. Wagner focused instead on the collective distributional "influence activities" of management and labor - an empirically significant supplement to the organizational dynamics examined by Milgrom and Roberts. Id. Wagner also highlighted - again with much recent empirical support - the cultural and psychological dynamics of commitment and resistance that inhere in centralized authority structures and that deeply affect work motivation and organizational performance. 
designed to safequard against opportunism, may tend to undermine the trust required to make the parties' commitments to those very rules credible - in the absence of the additional safeguard of workers' collective empowerment. ${ }^{442}$

Finally, several recent studies have elaborated yet another trustcrippling potential that Wagner saw in hierarchical workplace regimes. In these studies, both the narrow task-discretion built into the rulebound job classifications of the internal labor market and the systematic metering and co-worker competition of the employee rank hierarchy are powerful signals to workers of managerial distrust. Organizational pronouncements about consensual values and team cooperation are belied by these actual day-to-day practices, making the labor-management relationship highly vulnerable to the downward spiral that Alan Fox calls the "low-trust syndrome."443 Workers respond to their perceptions of managerial distrust with demoralization, resentment, and perfunctory performance, which may induce management to intensify metering and narrow worker discretion. Wagner's and his advisers' commitment to a combination of collective empowerment and collaborative shopfloor structures responded to this syndrome. The expanded participation of workers in discretionary workplace problem-solving ran counter, if only incrementally, to the narrow task-discretion that, for theorists like Fox, is the driving force behind the low-trust spiral.

In the United States, of course, management has historically seen unionization as a fecund source of distrust and polarization - the opposite of Wagner's expectations of collective bargaining. ${ }^{444}$ The

442 For recent evidence that confirms the tendency of collective bargaining over strategic managerial decisions to sustain trust, see sources cited below in note 484 .

${ }^{443}$ Fox, supra note 218 , at I02-I 4 ; see also sources cited infra note 486.

$444 \mathrm{~A}$ small minority of progressive managers in the I930s understood that relations with independent unions could be either low-trust or high-trust, and that managerial practices could be decisive in determining which orientation prevailed. Cyrus Ching, U.S. Rubber's Industrial Relations Director, wrote:

If, in dealing with labor organizations, we are ethical, are entitled to the confidence of people, use fair tactics and use friendly attitudes, we will get that in return; if we are going to be militant, use underhanded tactics and fight all the time, that is the type of organized labor leader we will get.

Cyrus Ching, Problems in Collective Bargaining, II J. Bus. 33, 40 (1938); see also Harold B. Bergen, Basic Factors in Present-Day Industrial Relations, I4 PERSONNEL 46, 58 (1937) (expressing similar views held by Proctor and Gamble's Director of Industrial Relations). But in the I930s, as today, management thinking about collective bargaining's effect on trust was generally grounded in the assumption that workers' "natural" or "objective" interests - and legitimate individual contractual obligations - lie in organic solidarity with the enterprise and in compliance with managerial directives. See supra p. 1460 . Hence, the emergence of collective adversarialism likely rests on workers' inaccurate perceptions of conflicting interests and on unions' fomenting of distrustful dispositions. If, as Wagner believed, workers' natural entitlements (and their likely subjective preferences) lie in the substantive freedom of collective em- 
managerial view tends, normatively, to discount the associational and redistributional interests of workers or, descriptively, to see their distributive struggles as strategic behavior necessarily reducing workers' absolute share by reducing the joint product of management and labor. Even if economists see workers' redistributive goal as legitimate or feasible, however, some identify plausible reasons to believe that unions' perceived institutional interests may encourage trust-undermining behavior. The union may prosper by encouraging workers to adopt an "us versus them" or "grievance" mentality. 445 While the possibility of such a strategy poses an ever-present threat to an enterprise otherwise suited to high-trust orientations, a large body of empirical evidence suggests that workers' loyalty to the union grows in tandem with workers' trust in the enterprise. 446 This "dual loyalty" thesis implies that a union's choice of a non-polarizing strategy is also instrumentally rational - a strategy trumpeted by interwar (and more recent) proponents of Wagner's collaborative brand of collective bargaining. ${ }^{447}$

(f) Wagner's Model in Sum: Gift-Exchange Through Empowerment. - In light of Wagner's emphasis on group commitments, trust, and the endogenous interests and norms that underpin them, the recent models of labor-management relations that best capture the basic conceptual structure of Wagner's philosophy are those based on

powerment, then cooperation and trust likely depend on fulfilling those interests, for the three reasons canvassed in the pp. 1483-84. Wagner quoted Arthur Todd approvingly:

The very nature of man cries out for association. If this impulse is not given free opportunity in the open and above board, it will inevitably work under cover, secretly. And this covert activity is likely to be much more devastating to employee loyalty, to managerial efficiency and to public confidence than overt unionism.

Wagner Brief, supra note 125 , at $44 \mathrm{I}$.

445 See Goldberg, supra note 369 , at $27 \mathrm{I}-72$.

${ }^{446}$ See, e.g., Lois R. Dean, Union Activity and Dual Loyalty, 7 INDUS. \& LAB. REL. REv. 526, 535 (I954); Michael E. Gordon, Laura L. Beauhais \& Robert T. Ladd, The Job Satisfaction and Union Commitment of Unionized Engineers, 37 INDUs. \& LAB. REL. REv. 359, 368 (I984); Anil Verma, Joint Participation Programs: Self-Help or Suicide for Labor?, 28 INDUS. REL. 40r, 408-09 (r989).

447

The capacity of [a labor union] to make men and women do their best, to rally to its standard the spiritual qualities which we variously designate as loyalty, devotion to duty, pride of achievement, is at once the envy and despair of company-union protagonists. . . .

....

. . Gone from the service [of company union workers] is the high quality of cooperative enterprise, valuable by-product of unionism; gone, the motivating impulse and enthusiasm for service, which grew out of the security and freedom of unionism; gone, too, the self-respecting kind of loyalty to a company which deserved loyalty fostered under unionism, and lost now even under a regime of dressmaking classes, ukulele instruction, and such tidbits of the new psychology.

Julia S. O'Connor, The Blight of Company Unionism, Am. Federationist, May, 1926, at 544, 546,548 . For recent evidence of the enabling - if not, as in Wagner's optimistic view, determinant - role of collective bargaining in enhancing trust, see below at pp. I493-94. 
anthropological "gift-exchange" theories. ${ }^{448}$ In these models, the twogroup bargaining game may yield a so-called gift exchange. Workers as a group give a "gift" of work effort and goodwill that exceeds perfunctory performance at the level of the firm's minimum work rules, and the firm gives a "gift" of compensation and relaxed monitoring conditions that are better than workers could find in the external labor market. The explanation for the "gift exchange" rests on a cluster of propositions that match Wagner's analysis.

First, worker interaction may generate trust-building sentiment among co-workers and between workers and the enterprise. ${ }^{449}$ In other words, as for Wagner, intra-group and inter-group interaction and communication alter welfare functions; interests and preferences are endogenous to institutional relationships. Workers' interaction produces sentiments that generate utility from working above the minimum standards set by the firm. ${ }^{450}$

Second, the interaction may also generate trust-building norms of fair exchange of group effort for compensation and monitoring conditions. ${ }^{451}$ Group norms and group sentiment are mutually reinforcing. Because of workers' sentiment for the work group, the firm "must at least to some extent treat the group of workers with the same norms, collectively." 452 In turn, the sentiments of goodwill toward the firm that underpin workers' willingness to give supra-minimum

448 The locus classicus of the concept of gift-exchange in the anthropological literature is Marcel Mauss, The Gift: The Form and Reason for Exchange in Archaic Societies passim (W.D. Halls trans., I990); see also CYRIL S. BELShaW, TRAditional EXChange AND MODERN MARKETS 46-52 (I965) (comparing gift-giving in traditional and modern societies, and concluding that it continues to play an important role in North American culture). The giftexchange concept has been applied to workplace relations by George Akerlof and Masahiko Aoki. See AOKI, supra note Io, at 176 ; George A. Akerlof, Labor Contracts as Partial Gift Exchange, 97 Q.J. ECON. 543, 557-67 (1982).

${ }^{449}$ As Akerlof argues:

Persons who work for an institution (a firm in this case) tend to develop sentiment for their co-workers and for that institution; to a great extent they anthropomorphize these institutions .... For the same reasons that persons (brothers, for example) share gifts as showing sentiment for each other, it is natural that persons have utility for making gifts to institutions for which they have sentiment.

Akerlof, supra note 448 , at 550 . For those who find this a bit rosy, consider Ashworth's evidence that even enemy soldiers in the trench warfare of World War I developed sentiments of caring from what began as purely instrumental interaction. See TONY AsHWORTH, TRENCH WARFARE 1914-I9I8: THE LIVE AND LET LIVE SYSTEM I9 (Ig80).

450 The gift-exchange model shows how group-based analysis can indirectly shed light on problems of individual workers' motivation and free-riding. See supra note 37r. In the giftexchange model, individual workers are motivated to provide intrinsic rather than perfunctory performance because of group-generated sentiments and norms. For empirical support of this claim, see sources cited infra notes $48 \mathrm{I}-485$ and accompanying text.

45I See supra pp. 1477-78.

452 Akerlof, supra note 448, at 544; see also Albert O. Hirschman, Against Parsimony: Three Easy Ways of Complicating Some Categories of Economic Discourse, I EcoN. \& PHIL. 7, I4 (I985) (expressing same idea). 
effort depend in part on the firm's honoring the group norms of fair exchange. ${ }^{453}$

Third, in the gift-exchange model, these sentiments and norms are rendered fragile by the context of workplace hierarchy. They are susceptible to corrosion in the face of excessive instrumental discipline by management. An intensification of monitoring and minimum standards, even if it targets only a few less productive workers, "might easily be considered by the group as a whole as failure by the firm to reciprocate the group's collective donation of productivity ... in excess of minimum requirements." $\$ 454$

Wagner's normative vision of workplace relations might be characterized as a gift-exchange-through-empowerment model. He and his advisers adopted 455 the three propositions underpinning the gift-exchange models, but gave greater weight to plausible mechanisms discussed in the previous section - by which enhanced worker bargaining power strengthens trust-building sentiments and norms. ${ }^{456}$

(g) Deliberative Trust and Hierarchical Resentment. - At the core of Wagner's understanding of collective bargaining lies a notion explored recently by Charles Sabel under the concept of "studied" or "deliberative" trust. ${ }^{457}$ That is, the norms and sentiments that allow

453 A recent MIT study of the automobile industry concludes that "workers respond [with high effort and quality work] only when there exists some sense of reciprocal obligation, a sense that management actually values skilled workers, will make sacrifices to retain them, and is willing to delegate responsibility to the team." JAMES P. WOMACK, DANIEL T. JONES, \& DANIEL Roos, The Machine That Changed the Wordd 99 (1990). Other empirical studies are cited below in notes $482-486$.

Whereas gift-exchange theorists identify potential non-instrumental benefits when management provides a supra-competitive compensation and monitoring package, other economists emphasize the instrumental benefits of such so-called "efficiency wages." Supra-market-clearing wages act as a disciplinary device because workers who are discharged for shirking suffer greater losses. See ANDREW WeIss, EfFiciency Wages: Models of UNEMPloyment, LAYoffs, AND WAGE Dispersion I-I4 (I9go); Carl Shapiro \& Joseph E. Stiglitz, Equilibrium Unemployment as a Worker Discipline Device, 74 AM. ECoN. REv. 433, 433 (1984).

454 Akerlof, supra note 448 , at 551 .

455 For Wagner's analyses prefiguring the three arguments of the gift-exchange model, see, respectively, above at pp. 1481-82, discussing group-generated worker motivation; above at $\mathrm{pp}$. 1477-97, discussing the development of norms of fair treatment and trust; and above at pp. 1483-84, discussing the fragility of trust within hierarchy.

456 In Akerlof's version of the gift-exchange model, no role is specified for the formal collective organization of workers, although he does note that gift-giving outcomes may have the consequence of diminishing worker mobility and may therefore induce greater inclination for workers to exercise collective voice through unionization. See Akerlof, supra note 448 , at $55^{\circ}$ n.5. Aoki, whose model is designed to capture the stylized facts of core Japanese workplaces, assumes the presence of an enterprise union, which monitors and sanctions management's compliance with the norms of gift-exchange over repeated bargaining rounds and thereby plays a significant role safeguarding against the loss of trust. See AokI, supra note 1o, at I 76; Taishiro Shirai, $A$ Theory of Enterprise Unionism, in CONTEMPORARY INDUSTRIAL RELATIONS IN JAPAN II7, I35 (Taishiro Shirai ed., r983).

457 See Sabel, supra note 2, at 27; Charles Sabel, Moebius-Strip Organizations and Open 
trusting cooperation in economic relationships need not be viewed as exogenous cultural facts that "explain" cooperative behavior only by the tautology that parties cooperate because they subscribe to cooperative norms or because they believe, for exogenous reasons, in each other's cooperative "reputation." In their ongoing economic dealings, parties not only meter each others' instrumental compliance with contractual specifications, but can also simultaneously engage in consultative interactions through which the norms and sentiments of trust are deliberately nurtured and warily monitored. ${ }^{458}$

For Sabel, as for Wagner, the course of such consultative dealings not only may build trust but also may endogenously redefine the subjective interests, perceptions, and even identities of the parties. Deliberative trust and interest-redefinition reflect the basic human capacity for self-reflexivity, in other words, for self-evaluation and self-transformation spurred by intersubjective communication, vulnerability, and assertion. 459

That Wagner's thinking reflected such abstract ideas is understandable in light of the progressivist intellectual atmosphere he breathed. Recall the traces in Wagner's writings of Dewey's declaration that cooperative institutions could "perfect[] the means and ways of communication of meanings so that genuinely shared interest in the consequences of interdependent activities may inform desire and effort and thereby direct action." 460 Wagner's attraction to a cooperative form of collective bargaining that encouraged collaborative consultation between workers and managers at all levels of the enterprise was a concrete instantiation of that abstract ideal.

Labor Markets, in Social Theory for a Changing Society 23, 32 (Pierre Bourdieu \& James S. Coleman eds., 199I).

${ }^{458}$ For Albert Hirschman as well, trust is a "resource[] whose supply may well increase rather than decrease through use," but may atrophy in institutions that fail to encourage otherregarding practices and norms, because institutional structures are premised solely on actors' instrumental self-interest. Hirschman, supra note $45^{2}$, at 17 ; see also SEN, supra note 1 , at $85-$ 87 (expressing same). Unger succinctly captures the subtle phenomonology of this process:

Though the ideal of reciprocity is repressed and restricted in associations of trust, it is not forgotten. It is as if the parties had agreed to remove this ideal from the forefront of concern so that it might be realized all the more smoothly and effectively; as if because no such bargain occurs in fact. The participants attach the demand of reciprocity to the ongoing experience of communal life rather than to particular exchanges in the course of the enterprise. . . .

[T] ]he vitality of communal life demands a willingness to overlook particular hardships and to count on the good faith of one's co-venturers. But the integrity of the group also requires a measure of vigilance to ensure that this trust not be abused . . . .

UNGER, supra note 420 , at 127,132 .

459 See Hirschman, supra note 452, at 19; Sabel, supra note 2, at 21-27; Sen, supra note $42 \mathrm{I}$, at 8-ir. For more extended treatment of the psychological underpinning of self-reflexive and inter-subjective social action, see DoNald Davidson, INQUIRIES INTO TRUTH AND INTERPRETATION 17-36, I24-40 (1984); and UNGER, cited above in note 420, at 275-300.

460 DEWEY, supra note 182 , at 155 . 
Wagner's insistence on collective empowerment and his opposition to company unionism reflected his understanding that cooperation and trust within hierarchy entailed vulnerability - vulnerability to either instrumental coercion or illegitimate shaping of workers' norms and interests by management's asymmetric power. Wagner and his progressive allies recognized, to an extent that contemporary transactioncost analysts have yet sufficiently to theorize, that even if "hierarchical governance" mitigates certain instrumental dilemmas, it also generates the trust-threatening cultural and psychological contests over legitimacy, commitment, resignation, and resentment that inhere in every authority or power relationship 461 - contests that very much affect organizational outcomes. That recognition flowed naturally from Wagner's view that the labor-management relationship was not just a horizontal exchange, but was embedded in an essentially political hierarchical structure, subject to the instrumental and symbolic struggles of any such structure.

\section{Conclusion: The Limits and Ambiguities of WAGNER'S VISION}

Confronting the rise of large-scale industry and its propertyless wage-labor force, labor republicans of the Gilded Age condemned the individual employment contract in much the same language that Wagner and his progressive circle were to use half a century later. ${ }^{462}$ There was no actual liberty of contract in the employer-employee relation because "when a man is without means to subsist upon, his wants compel him to work, and he must ask for employment as a favor from someone who has the property required to carry on productive work." 463 Because the workers "do not consent, [because] they submit but they do not agree," wage labor was a form of "industrial slavery.""464 Drawing on the traditional republican ideal that freedom and public citizenship could rest only on ownership of

461 See EAgLeton, supra note 240, at 45-6I; SCOTT, supra note 438 , at I08-35; UNGER, supra note 420 , at 126-34. The business community of the I920s through the r 940 s fully understood it was "engaged in a complex struggle for moral authority, not just a contest for power." Howell J. Harris, The Right to Manage io (Ig82).

462 On labor republicanism, see, for example, LEON FINK, WoRKINGMEN's DEMOCRACY passim (I983); DAvid MONTGOMERY, BEYOND EQUALITY: LABOR AND RADICAL REPUBLICANS, r862-1872 passim (1967); and Sean Wilentz, Chants Democratic: New York City aNd THE RISE OF THE AMERICAN WORKING ClASS, I788-1850, at 6i-IO3 (I984).

463 MONTGOMERY, supra note 462 , at 239 (quoting an unidentified eight-hour advocate of I87os), quoted in William E. Forbath, The Ambiguities of Free Labor: Labor and the Law in the Gilded Age, 1985 Wrs. L. Rev. 767, 811.

464 MonTgomery, supra note 462 , at 239 (quoting George McNeil, an eight-hour advocate), quoted in Forbath, supra note 463 , at $8 \mathrm{Ir}$. 
productive property, the labor republicans called for a "Cooperative Commonwealth." 465

But the "cooperative order" that labor progressives of the I930s envisioned for the supersession of the inherent "duress" of wage "slavery" differed dramatically from that of the labor republicans of the I870s. Labor republicans called for the end of the capitalist wage relationship itself and the erection of a "True Republic" based on cooperative ownership of industry by workers. ${ }^{466}$ Wagner, to the contrary, believed that capitalist ownership and hierarchical largescale production were the inevitable engines of economic progress. He believed that "free cooperation" 467 and full industrial and political "citizenship" and "self-mastery" 468 could nonetheless be secured for the propertyless worker within capitalist mass production through the collective empowerment of unionization. Indeed, he foresaw a regime of egalitarian communication and equal responsibility between labor and capital in the large-scale enterprise and in the democratic corporatist polity.

Wagner's progressive cooperativism perched perilously - as both a normative and descriptive matter - on the promise of empowerment afforded by collectivization of the labor market and on expectations of attendant transformations in workplace culture. His own pronouncements occasionally revealed the vulnerability of this vision. On the one hand, as detailed in this Article, he believed that the hightrust, cooperative workplace required an equalization of labor-management bargaining power and a softening of hierarchy in workplace problem-solving. Yet in his final substantive exchange in Senate debates on the Labor Relations bill, he insisted that the Act put no restrictions on management's traditional prerogative to impose discipline on workers who engaged in concerted activity contrary to the requirements of efficient production. ${ }^{469}$ His paeans to unions' capacity

465 MONTGOMERY, supra note 462 , at 252 , quoted in Forbath, supro note 463 , at 809 .

466 John Swinton, STRIKING FOR Life: LABOR's Side OF THE LABOR QUESTION 252-53 (1894), quoted in Forbath, supra note 463 , at 814 . On labor republicanism, see, for example, sources cited above in note 462 .

46779 CoNG. REC. 7573 (1935), reprinted in 2 LEgisLative HistoRY, supra note 38 , at 234I.

46875 CONG. REC. 4918 (1932).

469 In a colloquy with Senator Hastings, Wagner said:

Of course, if employees [engage in $\$ 7$ activity] when they should be working, they would be subject to discharge.

…

No sensible person would interpret $[\S 8(\mathrm{I})]$ to mean that while a factory is at work the workers could suddenly stop their duties to have a mass meeting in the plant on the question of organization.

79 CONG. REC. 7676 (1935), reprinted in 2 LEgisLative HistoRy, supra note 38 , at 2401 . The values and assumptions of hierarchical control that several critical scholars have uncovered in the decisions under the Wagner Act were thus embedded ambivalently in Wagner's own thinking. 
to discipline "irresponsible" individuals and minorities likewise suggest the limits of the egalitarian cooperation and individual self-mastery that the new regime would implement. Neither of these concessions to hierarchy necessarily clashes with Wagner's core ideal of workers' majoritarian consent to modes of workplace governance. That is, in theory a workforce could democratically consent to hierarchical discipline. ${ }^{470}$ But, in a striking aside in his 1937 victory speech at Yale Law School after the Jones and Laughlin decision, ${ }^{471}$ Wagner candidly expressed doubts about the possibility of realizing within the regime of wage labor the consent-defining "equality" of bargaining power that had for years been the normative North Star of his legislative program. 472

Some economic historians characterize the I940s and I950s as a period of relative labor-management cooperation stemming, as Wagner had theorized, from organized labor's capacity to restore workers' trust that management would adhere to fair norms of gift-exchange - trust that had been shattered by Depression-era wage and employment cuts. ${ }^{473}$ Nonetheless, while members of Wagner's own circle continued after the I930s to promote his cooperative vision of a highly collaborative, integrationist mode of collective bargaining, ${ }^{474}$ that full-

470 See Putterman, supra note 309 , at $\mathbf{1 7 2 .}$

471 NLRB v. Jones \& Laughlin Steel Corp., 301 U.S. I (1937).

472 See Wagner, supra note 129, at I5-16 ("The restrictions placed upon the worker economic, social and legal - are so tremendous that he probably would not have equality of bargaining power even if the National Labor Relations Act were obeyed in full."). This admission prefigured the fundamental defect that Professor Stone identifies in postwar statutory interpretations that rest on a false premise of equality of bargaining power between labor and management. See Stone, Post-War Paradigm, supra note 8, at 1544-59. Of course, "equality" of bargaining power for Wagner was a mere label for the labor market conditions and relative employer-employee bargaining power that he considered just. How to define what degree of relative bargaining power is just and when that degree has been institutionally secured in vastly different historical contexts is one of the key puzzles of any attempt to adapt Wagner's collaboration-through-empowerment model of the I930s to the team workplaces of the Iggos. See Barenberg, supra note 28.

473 See sources cited infra note 477 . William Lazonick's recent study concludes:

Before the Great Depression, many of the dominant mass producers [though a minority of large employers] had, in the absence of unions, undertaken to provide shop-floor workers with employment stability and even systematic pay increases in order to elicit effort and maintain the flow of work. But after the debacle of the I930s, it is unlikely that American blue-collar workers would have placed their trust in these companies to provide "good jobs." Assurance that corporate promises of stable employment and rising incomes would be kept required the presence of powerful unions. Particularly during World War II, many nonunion employers found that, without a union to support workers [sic] claim to a share of the firm's value gains, the shop floor became unmanageable.

William Lazonick, Competitive AdVANTAGe on the Shop Floor 276-77 (Iggo).

474 See, e.g., Morris Cooke \& Phillip Murray, Organized Labor and Production passim (1940); Sumner H. Slichter, James J. Healy \& E. Robert Livernash, The IMPact of Collective Bargaining ON Management 84i-78 (ig6o); Sumner H. Slichter, The Challenge of Industrial Relations 170-75 (1947). 
blown model never became the norm. Wartime labor policy, ${ }^{475}$ the Taft-Hartley Amendments, and post-War administrative and judicial interpretations helped secure a more adversarial mode of unionization, ${ }^{476}$ even if workers achieved a substantial degree of de facto "mutualism" in shop-floor decision-making. 477 Labor progressives' hopes for the immediate achievement of a labor-corporatist society died by the the early rg6os, if not much earlier. ${ }^{478}$

In a Pyrrhic vindication of Wagner's vision, the last two decades have seen a revival of practical schemes of labor-management cooperation, linked with new theoretical and empirical confirmation of the major elements of Wagner's progressivism. ${ }^{479}$ Although Wagner's optimistic premise that collective bargaining would inevitably generate a high-trust workplace reflects an overly deterministic conception of the relation between institutional structures and consciousness, ${ }^{480}$ the

475 Business executives and their allies in the military procurement and defense planning agencies rejected the ClO's wartime call for tripartite "industrial councils" to run each industry. The War Production Board attempted to mollify the CIO by sponsoring plant-level, labormanagement production committees. Owing to business pressure, however, even the few committees that were effectively implemented excluded union officers and fully preserved managerial prerogatives. See Nelson Lichtenstein, Labor's WaR at HoMe: The CIO IN WORLD WaR II $89-90$ ( 9982$)$.

476 The Taft-Hartley Amendments, among other things, rejected proposals to codify the wartime labor-management committees discussed above in note 475 , and excluded supervisors from the Act's protection. See NLRA, supra note $3, \S 2(3), 29$ U.S.C. § 152(3) (1988). Decisional law extended that exclusion to all managerial employees, see, e.g., NLRB v. Bell Aerospace Co., 4I6 U.S. 267, 275 (1974), and prohibited both supervisory and managerial employees from participating actively in common labor organizations with rank and file employees, see, e.g., Sierra Vista Hospital, Inc., 24I N.L.R.B. 63I, 633 (1979); see also KoIKE, supra note 20, at 237-39 (contrasting the United States with Germany and Japan in this respect). This deterrent to collaborative blurring of the labor-management divide was reinforced by a number of other doctrinal developments, see Stone, Labor and Corporate Structure, supra note 8, at 138-6r, but also by what Arthur Goldberg called the "incalculable effects" on "industrial mores" caused by Taft-Hartley, CIO, Proceedings of the Eleventh Constitutional Convention 124 (r949) (quoting Goldberg).

477 See Neil W. Chamberlain, The Union Challenge to Management Control 89I28 (I948); James W. Kuhn, Bargaining in Gruevance Settlement: The Power of INDUSTRIAL WORK GROUPS I74-76 (I96I); Jeffrys, supra note 247, at I00, 122-23.

478 See, e.g., LAzoNICK, supra note 473, at 276-80; Nelson Lichtenstein, From Corporatism to Collective Bargaining, in THE RISE AND FALL OF THE NEW DEAL ORDER, 1930-1980, supra note 44, at 122, I22-23 (arguing that corporatist hopes ended in 1946-48); David L. Stebenne, Arthur J. Goldberg, New Deal Liberal passim (rggl) (unpublished Ph.D. dissertation, Columbia University) (arguing that the imminent construction of corporatism did not seem foreclosed until the early I960s); supra note 21 . Faith in Wagner's visionary brand of progressivist cooperationism was, according to Alan Brinkley, already "in retreat" among New Dealers by the late I930s. Brinkley, supra note 180 , at 85,93 .

479 Whether and under what conditions even the collective empowerment of independent unionism protects workers against illegitimate coercion and preference-transformation in such cooperative workplaces, as Wagner assumed, is a contested question that I take up in Barenberg, cited above in note 28 .

480 See supra note 354 ; infra pp. 1493-94. For evidence of such contingency in the specific context of collaborative labor-management relations, see Barenberg, supra note 28; Edward $\mathrm{H}$. 
empirical and theoretical grounds for the "enabling" role of collective empowerment in trust-enhancement now seem persuasive. 481 The most recent and thorough set of empirical studies - although by no means the final or uncontested word - on the cooperative schemes of the rg8os and rggos conclude that, for reasons essentially similar to those offered by Wagner, collaborative arrangements in unionized workplaces generally yield greater productivity, ease of technological transformation, and active worker participation than in non-unionized workplaces. ${ }^{482}$ These studies confirm that an increased workers' role in workplace decisionmaking tends to enhance workers' sense of responsibility and commitment to the decisions they help make and to enterprise goals more generally; 483 that collective participation in strategic corporate decisions bolsters workers' confidence that their enhanced effort and initiative, acceptance of flexible work rules, and short-term wage restraint will be fairly rewarded in the future; ${ }^{484}$ and

Lorenz, Trust and the Flexible Firm: International Comparisons, 3I INDUS. REL. 455, 457 (I992).

481 "Most U.S. studies indicate a positive union productivity effect, but there are enough counter-examples to suggest that it is the state of labor relations rather than unionism and collective bargaining per se that determines productivity." David G. Blanchflower \& Richard B. Freeman, Unionism in the United States and Other Advanced OECD Countries, $3 \mathrm{I}$ INDus. REL. 56, 68 (I992). Unger points out that the contingent, but enabling, relation between empowered reciprocity and trust is a general phenomenon in social life. See UNGER, supra note 420 , at $128-29$.

482 See Maryellen R. Kelley \& Bennett Harrison, Unions, Technology, and Labor-Management Cooperation, in UNIONS AND ECONOMIC COMPETITIVENESS 247, 276-77 (Lawrence Mishel \& Paula B. Voos eds., I992) (concluding from study of over I000 union and non-union plants that collaborative problem-solving is more successful in unionized plants because of employment security and trust provided by collective bargaining, although unionization enhances efficiency more than do formal participation schemes); see also Adrienne E. Eaton \& Paula B. Voos, Unions and Contemporary Innovations in Work Organization, Compensation, and Employee Participation, in UNIONS AND ECONOMIC COMPETITIVENESS, supra, at 173 , I8I (reaching same conclusion, reinforced by fact that unionized, unlike non-unionized, workplaces have an institutionalized procedure to discuss and negotiate the exchange of greater productivity for greater wages and security); Lorenz, supra note 480 , at $462-63$ (reaching same conclusion based on international comparative data); Lowell Turner, Industrial Relations and the Reorganization of Work in West Germany: Lessons for the United States, in UNIONS AND ECONOMIC CoMPETITIVENESS, supra, at 217, 220-24I (reaching same conclusion based on West Germany's combination of independent unionism with collaborative workplace structures). But cf. HIRSCH, supra note 403 , at $87-89,122$ (concluding that, whereas unions cause a decrease in enterprise investment, their effect on productivity is ambiguous); William N. Cooke, Product Quality Improvement Through Employee Participation: The Effects of Unionization and Joint UnionManagement Administration, 46 INDUS. \& LAB. REL. REV. IIg, IIg (I992) (concluding that product quality in joint union-management participation programs is "at least equal" to that in nonunion participation programs).

483 See, e.g., Chardes C. Heckscher, The New Unionism: Employee Involvement in the Changing Corporation 5-6, 88-89, 25 I (rg88); David E. Guest, Human Resources Management and Industrial Relations, 24 J. MGMT. STUD. 503, 512-14 (1987); Edward E. Lawler III, Pay for Performance: A Motivational Analysis, in INCENTIVEs, Cooperation, AND RISK SHARING, supra note 375 , at $69,78-79$.

484 See, e.g., AOKI, supra note Io, at I6; KochaN, KATZ \& McKersie, supra note ro, at i6. 
that flattened managerial hierarchies, team production processes, and group-based pay systems often provide greater productivity gains than would be predicted by self-interested rationalist theories of free-riding and moral hazard. ${ }^{485} \mathrm{~A}$ recurrent failing of the new cooperative work arrangements, however, is workers' low-trust response to "drill sergeant" supervisors and to managerial practices that undermine union strength and involvement. 486 This challenges Wagner's conviction that collective bargaining would inevitably sustain trust, but confirms his recognition that hierarchical labor-management structures are highly vulnerable to the "low-trust syndrome."

In the last twenty years, collaborative schemes were also implemented widely in non-union enterprises, and they gelled into a relatively stable mode of workplace governance that reflected and reinforced the precipitous, decline of organized labor. ${ }^{487}$ The failure of the Wagner Act regime (as amended and actually administered) to guide managerial culture toward cooperationist acceptance and trust in collective bargaining was registered in intensified managerial resistance to union organizing campaigns. 488 The anticipated collective empowerment that, in Wagner's view, promised to build trust and loyalty continued instead to feed managerial resistance and distrust. ${ }^{489}$

485 See, e.g., John W. Kendrick, Group Financial Incentives: An Evaluation, in INCENTIVEs, COOPERATION, AND RISK SHaring, supra note 375, at 120, I32; Haig R. Nalbantian, Incentive Compensation in Perspective, in INCENTIVEs, COOPERATION, AND RISK SHARING, supra note 375, at 3, 35; Edward J. Ost, Team-Based Pay: New Wave Strategic Incentives, Sloan MgmT. REV., Spring, Ig9o, at I9, $21-22$.

${ }^{486} \mathrm{See}$, e.g., William N. Cooke, Labor-Management CoOperation IO4-05 (1990); Lloyd TURner, Democracy at Work: Changing World Markets aNd the Future of LABOR UNIONS 3I-90 (I991); Cooke, supra note 482, at 124-25, I32; Lorenz, supra note 480, at 457 .

487 See KochaN, KATZ \& MCKERSIE, supra note Io, at 47-80.

488 See, e.g., William N. Cooke, The Rising Toll of Discrimination Against Union Activists, 24 INDUS. REL. 421, 42 I (1985); Richard B. Freeman \& Morris M. Kleiner, Employer Behtavior in the Face of Union Organizing Drives, 43 INDUS. LAB. REL. REv. 35I, 35I (I990); Weiler, supra note 290 , at $1776-81$. There are, of course, many sources of deunionization and labor disempowerment other than the escalation of management anti-union campaigns, including heightened international and domestic competition, enhanced capital mobility, excessive union wage premiums, unions' bureaucratic ossification, and increasing cultural legitimation of management's hiring of strike replacements. See, e.g., Hirsch, supra note 403, at 118-22; Blanchflower \& Freeman, supra note 481, at 57-60; Henry S. Farber, The Recent Decline of Unionization in the United States, 238 SCIENCE 915, 916-19 (1987).

Continued managerial anti-unionism not only undermined employers' acceptance of collectivization. It also discouraged established but weak unions from supporting the diffusion of cooperative experiments for fear that management would use them as union-subverting mechanisms. See, e.g., CoLE, supra note 9, at 150-51.

489 Signs of a managerial counter-offensive against the strengthened labor movement that emerged from World War II were visible immediately after the war and increasingly prevalent throughout the ig5os. See Mike Davis, Prisoners of the American Dream I04, 121-23 (I986); Harris, supra note 246, at I I8-27; HARRY A. Millis \& EMIly C. Brown, From the WAGNER ACT TO TAFT-HARTLEY 293-94 (I950). 
Wagner's optimistic vision of a legislatively nurtured culture of cooperation underestimated "the deep-seated resistance toward unions that historically has been embedded in the belief system of U.S. managers" - more deeply embedded than in any other industrial nation's business culture. ${ }^{490}$

American management's adversarial psychology is traceable in part to certain tightly intertwined historical institutional patterns. First, the enterprise-level decentralization of American industrial relations raised the competitive economic stakes for any individual firm targeted for unionization in an otherwise non-unionized industry, compared with the industry-wide collective bargaining of many European economies. 491 Second, the pre-eminence of mass production in American industrial organization placed a premium on centralized managerial discretion to coordinate decomposed production tasks. ${ }^{492}$ Finally, the historically fortuitous collision between strong craft unionism and management's drive for high-throughput, mass production in the late nineteenth century implanted lasting managerial commitments to deskill production labor and to retract discretionary authority from the shopfloor to the managerial strata. ${ }^{493}$

But, ironically, Wagner also underestimated management's awareness and fear of the potency of the very process of cultural change he extolled and urged among workers. Many American managers, before and after the New Deal, were convinced that the normative legitimation of collective bargaining risked opening a cultural Pandora's Box. Workers' appetite for decisionmaking authority, organizational democracy, and redistributive power would grow with the eating. 494 Precisely for that reason, the bulk of interwar managers opposed even the limited collective dealing of company unionism, until the latter became the only apparent strategy to block independent unionism after the enactment of section 7 (a) of the Recovery Act. ${ }^{495}$

Concurrently, and in part as a consequence, Wagner overestimated the new legal regime's long-term capacity or willingness to reduce the (substantially management-generated) transaction costs incurred by workers who attempt to move to a labor-share-enhancing but profit-

490 Kochan, Katz \& McKenzie, supra note 10, at 14.

491 See, e.g., Derek C. Bok, Reflections on the Distinctive Character of American Labor Laws, 84 HARV. L. REV. I394, I400-58 (I971); Rogers, supra note 8, at 80-98.

492 See, e.g., PIORE \& SABEL, supra note IO, at 64.

493 See LAZONICK, supra note 473 , at 292-98, 302-03.

494 See Barenberg, supra note 28.

495 According to one Wagner adviser, most managers believed that any such liberalization would "give the workmen exaggerated notions of their rights and management desires to keep the workers' minds off their rights." SUMNER SCHLICHTER, THE Turnover in Factory Labor 319 (192 I). On management's last-ditch resort to company unionism after the passage of $\S 7(\mathrm{a})$, see, for example, BUREAU OF LABOR STATISTICS, cited above in note 16 , at 6-30. 
reducing unionized state. ${ }^{496}$ The relative loosening of business constraints on labor law policy - the structural veto - during the Depression years that had permitted such radical legislation did not last into the post-war period. 497

Each of these two developments - de-unionization and the new cooperative workplace - highlights the ambivalence and tension in Wagner's own thinking. The success of management's aggressive antiunion campaign, combined with heightened capital mobility and international competitiveness, pose the basic question implicitly explored by a number of recent commentators: ${ }^{498}$ Can the labor law regime secure free worker communication and choice of workplace governance modes, against a background regime of property, contract, and corporate law, and a background distribution of endowments, which afford strategic control of enterprises to suppliers of capital? The emergence of the new cooperative workplace reraises, in a dramatically changed historical context, the fundamental question that Wagner's political economy and legislative program attempted to answer: What legal regime can best encourage collaborative, high-trust workplaces, and simultaneously empower and safeguard workers against "domination," understood as illegitimate instrumental coercion and endogenous shaping of workers' preferences and interests? Even if his specific institutional vision remains unfulfilled, Wagner's progressivism and its current variants at least provide a general theoretical framework for addressing the latter question. ${ }^{499}$

496 The leading empirical studies agree that unionization raises labor's and reduces capital's distributive share, even if those studies disagree about whether unionization raises productivity. See, e.g., FREEMAN \& MEDOFF, supra note 388, at $162-90$ (arguing that unions raise productivity); HIRSCH, supra note 403, at 35-66, 9I-III, II5-25 (arguing that evidence of unions' effect on productivity is inconclusive). As noted above at p. 1474, Wagner also did not anticipate the heightened mobility of capital and its effects in the postwar period.

497 The business community's biggest postwar political efforts were devoted to winning the Taft-Hartley Amendments of 1947 and defeating the Labor Law Reform bill of 1978. See HARRIS, supra note 65, at I18-27; Millis \& BRowN, supra note 489, at 281-96; Weiler, supra note 290 , at $1776-8 \mathrm{I}$. The primary goal of the latter bill was simply to enhance enforcement of the basic goal of the original Wagner Act - that is, reducing the transaction costs of workers' choice to unionize - through stronger penalties for employer unfair labor practices. See id. at 1770.

498 For a sample of this voluminous literature, see Michael Goldfield, The Decline of ORGaNized LABOR IN THE UNITEd States II5-179 (I987); JoHN J. LAWLER, UNiONIZATION AND Deunionization I-6 (I990); and Paul C. Weiler, Hard Times for Unions: Challenging Times for Scholars, 58 U. CHI. L. REV. 1015, I03I (I99I) (responding to Robert J. LaLonde and Bernard D. Meltzer, Hard Times for Unions: Another Look at the Significance of Employer Illegalities, 58 U. CHr. L. REv. 953 (199r)); sources cited supra note 488.

499 See Barenberg, supra note 28. 